\title{
Synthesis and Characterization of Thiophosphoramidate Morpholino Oligonucleotides and Chimeras
}

\author{
Heera K. Langner*, Katarzyna Jastrzebska†, Marvin H. Caruthers* \\ Department of Chemistry and Biochemistry, University of Colorado at Boulder, Boulder, Colorado 80309, \\ United States. \\ Email: krishna.heera@colorado.edu; marvin.caruthers@colorado.edu
}

\section{Supporting Information}

\section{General Procedures}

Chemical Synthesis: Commercially available DNA synthesis reagents were purchased from Glen Research (Sterling, VA) or ChemGenes Corporation (Wilmington, MA). Column chromatography purification of morpholino synthons was carried out using $60 \AA$ standard grade silica gel from Sorbent Technologies (Norcross, GA). Thin-layer chromatography was performed on aluminum-backed silica $60 \mathrm{~F}_{254}$ plates from Merck EMD. ${ }^{1} \mathrm{H}$ and ${ }^{31} \mathrm{P}$ NMR spectra were recorded at $25^{\circ} \mathrm{C}$ using a Bruker Avance-III $400 \mathrm{MHz} \mathrm{NMR}$ spectrometer. 5'-DMT-protected ribonucleosides of $\mathrm{N}^{6}$-benzoyl adenosine, $\mathrm{N}^{4}$-benzoyl cytidine, and $\mathrm{N}^{2}$ isobutyryl guanosine were purchased from ChemGenes Corporation (Wilmington, MA). 5'-DMT-5methyluridine was purchased from BioSynth-Carbosynth (San Diego, CA). All other reagents and solvents were obtained from commercial suppliers and used without further purification.

Solid-phase Synthesis: All standard phosphoramidites, 5'-fluorescein phosphoramidite, 5'-DMT-2'deoxyribonucleotide-CPG, Universal support III, and 5'-DMT-2'-OMe-RNA-CPG columns (1.0 $\mu \mathrm{mol}$ synthesis scale) were purchased from Glen Research (Sterling, VA). All solid-phase syntheses were carried out using an Applied Biosystems Model 394 Automated DNA Synthesizer using conventional DNA synthesis reagents unless otherwise noted.

HPLC Methods: Analytical HPLC injections were carried out using a Discovery ${ }^{\circledR}$ C18 HPLC column, $5 \mu m$ particle size, $L \times I . D .15 \mathrm{~cm} \times 4.6 \mathrm{~mm}$ eluting at $1.5 \mathrm{~mL} / \mathrm{min}$ using an increasing gradient of acetonitrile in $50 \mathrm{mM}$ triethylammonium bicarbonate buffer, $\mathrm{pH}$ 8.5. When required for further analysis, the peak fractions were collected manually and evaporated to dryness using a SpeedVac Concentrator (Thermo Fisher Scientific).

Oligonucleotide Purification: Semi-preparative purification of DMT-On oligonucleotide reaction mixtures were carried out by ion-pair reverse-phase HPLC using the Agilent Zorbax SB-C18, $5 \mu \mathrm{m}$ column $9.4 \mathrm{~mm}$ i.d. $\times 250 \mathrm{~mm}$ on an Agilent $1100 \mathrm{HPLC}$. The eluent was monitored for absorption at $254 \mathrm{~nm}$. Buffer A (50 $\mathrm{mM}$ TEAB in water) and eluent $B$ (acetonitrile) were used to generate a gradient from $3 \%$ to $100 \%$ of eluent $B$ over 40 minutes at a flow rate of $2 \mathrm{~mL} / \mathrm{min}$. The eluent fractions were collected using a Gilson 
FC-204 fraction collector. Pooled fractions were evaporated to dryness in a SpeedVac Concentrator and analyzed by LCMS for purity. DMT-Off oligonucleotides (generated by treatment of pure DMToligonucleotides with $50 \%$ aqueous acetic acid for 5 minutes) were also purified using this procedure to obtain pure oligonucleotides for downstream experiments.

\section{Chemical Synthesis of Morpholino Phosphorodiamidites (4a-d)}

Detailed synthetic procedures for the preparation of morpholino nucleosides is described in chemical synthesis section (main text) and is also available in [1]. Appropriately protected morpholino nucleosides (Scheme 1, 3a-d) were dried in vacuo overnight. To synthesize the morpholino phosphorodiamidites 4ad, $4.8 \mathrm{mmol}$ of morpholino nucleoside was dissolved in $250 \mathrm{~mL}$ dichloromethane, followed by the addition of 2-cyanoethyl- $N, N, N^{\prime}, N^{\prime}$-tetraisopropylphosphorodiamidite (1.2 equiv., $5.76 \mathrm{mmol}$ ). After adding 5Ethylthio-1H-Tetrazole (ETT, 0.5 equiv., $2.4 \mathrm{mmol}$ ), the reaction mixture was allowed to stir for 30 minutes at $25^{\circ} \mathrm{C}$. The reaction mixture was concentrated in vacuo and the product isolated by flash column chromatography to yield pure phosphorodiamidite (Scheme 1, 4a-d). Prior to loading the reaction mixture, the silica was neutralized using a mixture of 1:1 Hexane-Ethylacetate containing anhydrous $3 \%$ triethylamine in order to prevent detritylation. Column chromatography was performed using an isocratic mixture of 1:1 Hexane-Ethylacetate. Fractions containing pure product (as observed by TLC) were pooled and evaporated to dryness.

Compound 4a: 6'-O-(4,4'-Dimethoxytrityl)-3'-O-cyanoethyl-1'-( $\mathbf{N}^{6}$-benzoyladenosine) morpholino(N,N'diisopropylamino) phosphorodiamidite.

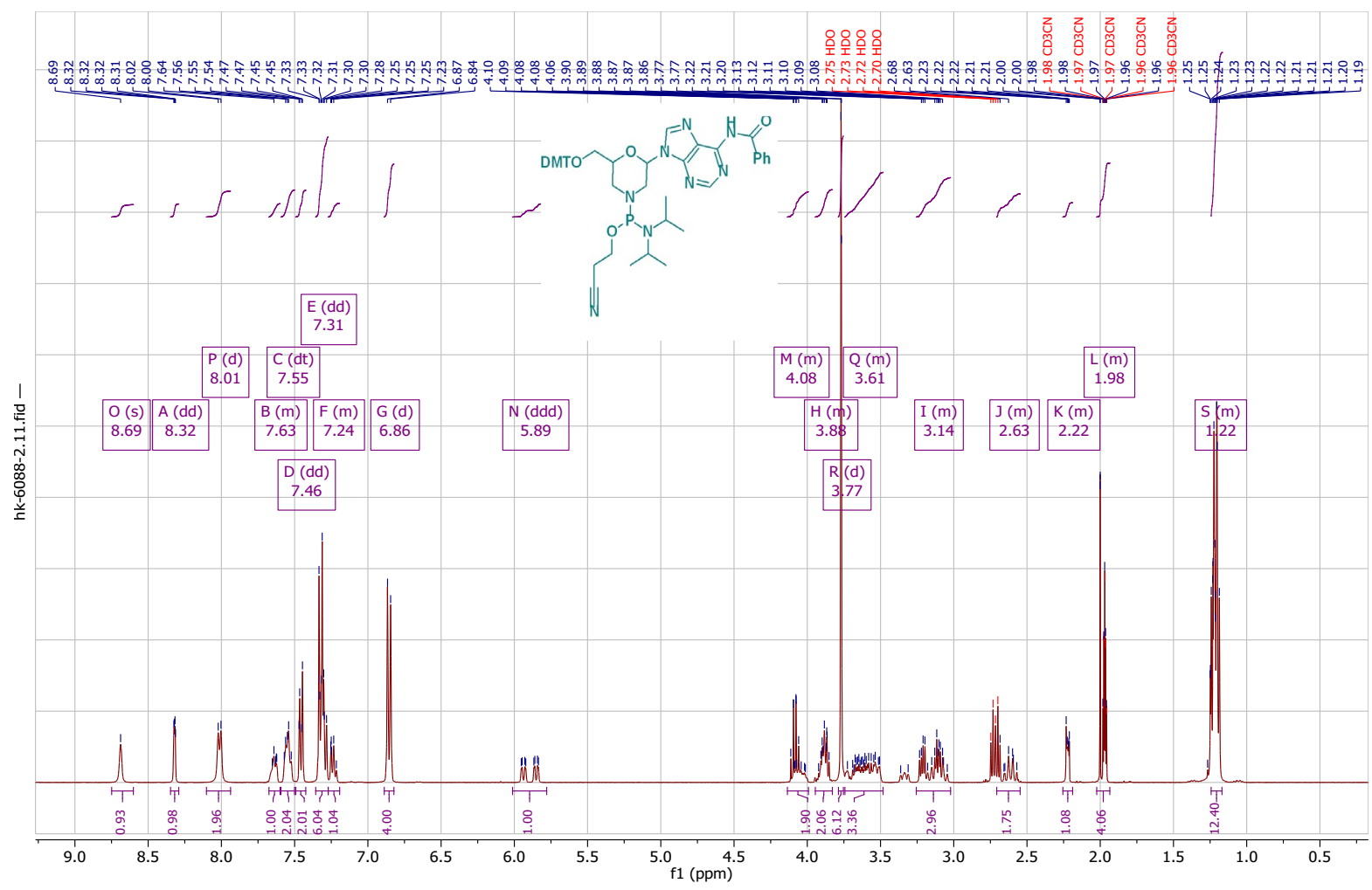

${ }^{1} \mathrm{H}$ NMR Spectrum (400 MHz, $\mathrm{CD}_{3} \mathrm{CN}$ ) of Compound 4a 


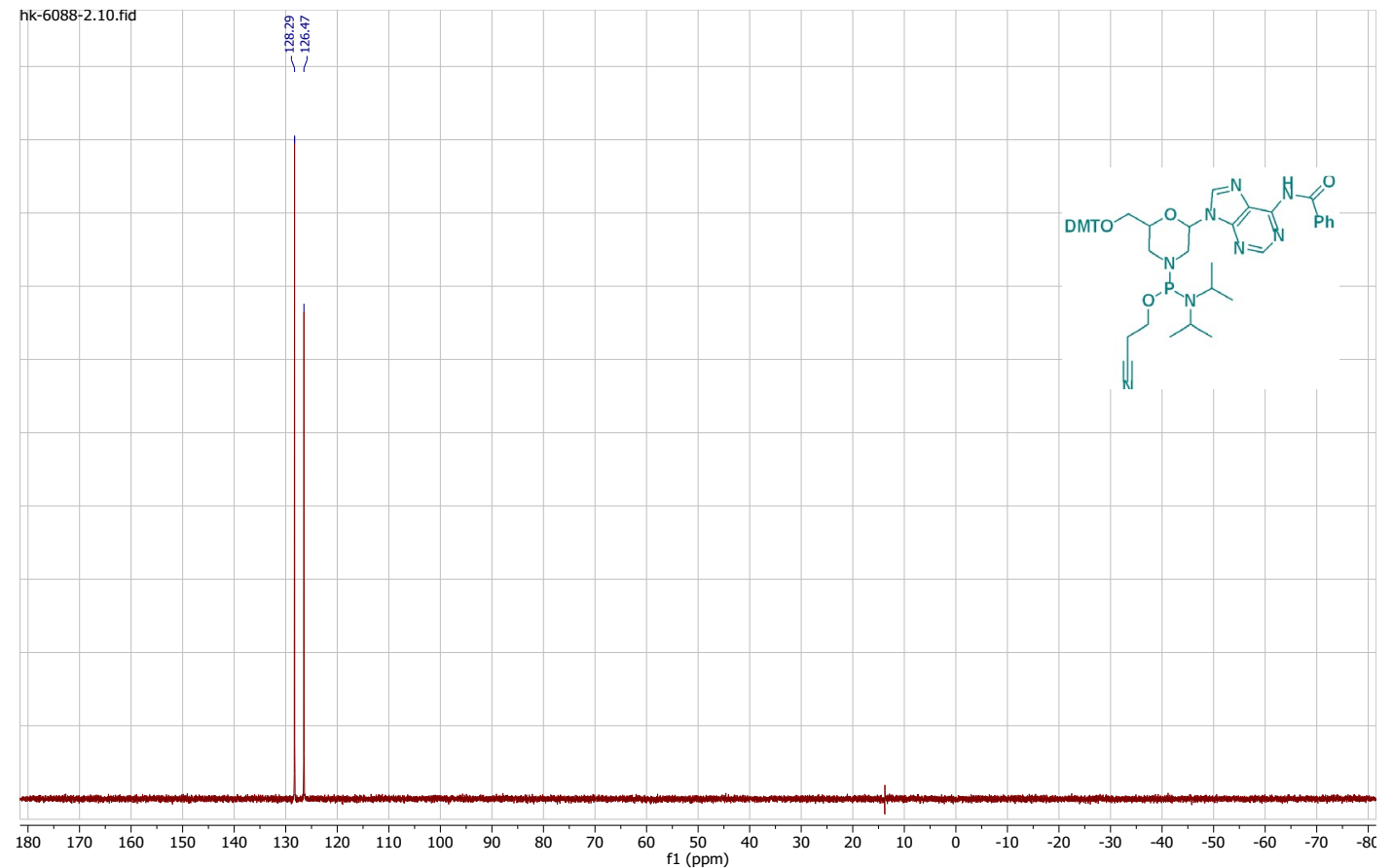

${ }^{31} \mathrm{P}\{1 \mathrm{H}\}$ NMR Spectrum (400 MHz, $\mathrm{CD}_{3} \mathrm{CN}$ ) of Compound $4 \mathrm{a}$

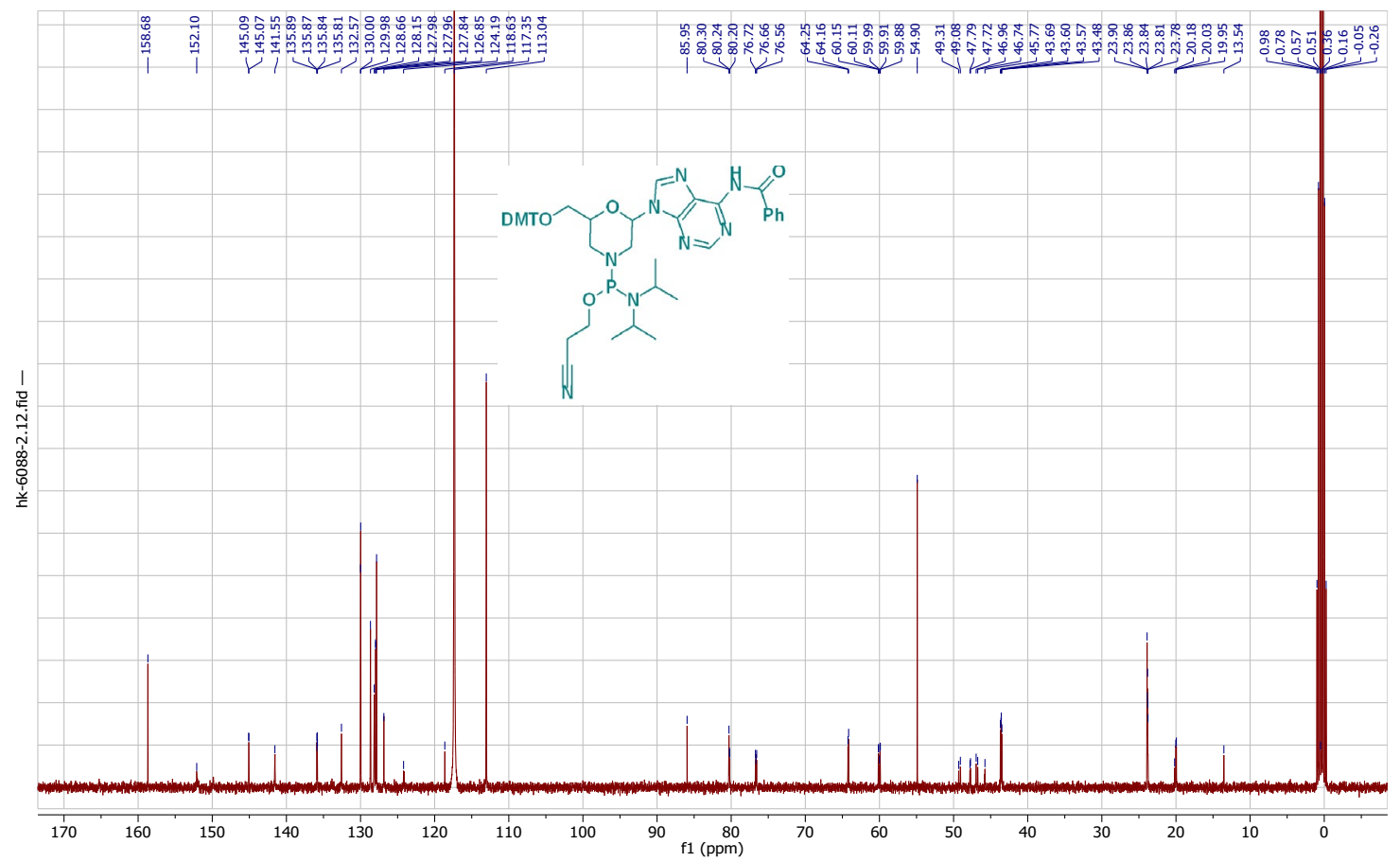

${ }^{13} \mathrm{C}$ NMR Spectrum (400 MHz, $\mathrm{CD}_{3} \mathrm{CN}$ ) of Compound $4 \mathrm{a}$ 
Compound 4a was prepared by following the general experimental procedure using morpholino nucleoside 3a (3.15g, $4.8 \mathrm{mmol}$ ), Bis(diisopropylamino)(2-cyanoethoxy)phosphine (1.2 equiv., 5.76mmol, $1.83 \mathrm{~mL}$ ) and $0.25 \mathrm{M}$ 5-Ethylthio- $1 H$-Tetrazole (0.5 equiv, $2.4 \mathrm{mmol}, 9.6 \mathrm{~mL}$ ) in anhydrous dichloromethane. ${ }^{1} \mathrm{H}$ NMR $\left(400 \mathrm{MHz}\right.$, Acetonitrile- $\left.\mathrm{d}_{3}\right) \delta 8.69(\mathrm{~s}, 1 \mathrm{H}), 8.32(\mathrm{dd}, \mathrm{J}=3.1,1.3 \mathrm{~Hz}, 1 \mathrm{H}), 8.01(\mathrm{~d}$, J $=7.6 \mathrm{~Hz}, 2 \mathrm{H}), 7.68-7.60(\mathrm{~m}, 1 \mathrm{H}), 7.55(\mathrm{dt}, \mathrm{J}=10.5,5.3 \mathrm{~Hz}, 2 \mathrm{H}), 7.46(\mathrm{dd}, \mathrm{J}=7.4,1.9 \mathrm{~Hz}, 2 \mathrm{H}), 7.31(\mathrm{dd}, \mathrm{J}=$ $12.4,8.3 \mathrm{~Hz}, 6 \mathrm{H}), 7.27-7.19(\mathrm{~m}, 1 \mathrm{H}), 6.86(\mathrm{~d}, \mathrm{~J}=8.4 \mathrm{~Hz}, 4 \mathrm{H}), 5.89$ (ddd, J = 34.6, 9.8, $2.6 \mathrm{~Hz}, 1 \mathrm{H}), 4.14-$ $3.99(\mathrm{~m}, 2 \mathrm{H}), 3.95-3.83(\mathrm{~m}, 2 \mathrm{H}), 3.77(\mathrm{~d}, \mathrm{~J}=1.3 \mathrm{~Hz}, 6 \mathrm{H}), 3.74-3.48(\mathrm{~m}, 3 \mathrm{H}), 3.26-3.02(\mathrm{~m}, 3 \mathrm{H}), 2.71-$ $2.55(\mathrm{~m}, 2 \mathrm{H}), 2.25-2.19(\mathrm{~m}, 1 \mathrm{H}), 2.02-1.93(\mathrm{~m}, 4 \mathrm{H}), 1.24-1.17(\mathrm{~m}, 12 \mathrm{H}) .{ }^{13} \mathrm{C}$ NMR $(101 \mathrm{MHz}$, Acetonitrile$\left.d_{3}\right) \delta 158.68,145.09,145.07,141.55,135.89,135.87,135.84,135.81,132.57,130.00,129.98,128.66$, $128.15,127.98,127.96,127.84,126.86,118.63,117.35,113.04,85.95,80.30,80.24,76.72,76.56,64.25$, $64.16,60.15,60.11,59.91,59.88,54.90,43.69,43.60,43.57,43.48,23.90,23.86,23.84,23.81,23.78$, 20.03, 19.95, 13.54. ${ }^{31} \mathrm{P}$ NMR $\left(162 \mathrm{MHz}\right.$, Acetonitrile- $\left.\mathrm{d}_{3}\right) \delta 128.29,126.47$. ESI calcd. for $\left[\mathrm{C}_{47} \mathrm{H}_{53} \mathrm{~N}_{8} \mathrm{O}_{6} \mathrm{P}\right]$ : 856.3826 , found $[\mathrm{M}+\mathrm{H}]^{+}: 857.3909$ Yield 4a: $2.75 \mathrm{~g}, 67 \%$.

\section{Compound $\quad 4 \mathrm{~b}: \quad 6$ ' -0 -(4,4'-Dimethoxytrityl)-3'-O-cyanoethyl-1'-( $\mathrm{N}$-isobutyrylguanosine) morpholino(N, $\mathrm{N}^{\prime}$-diisopropylamino) phosphorodiamidite.}

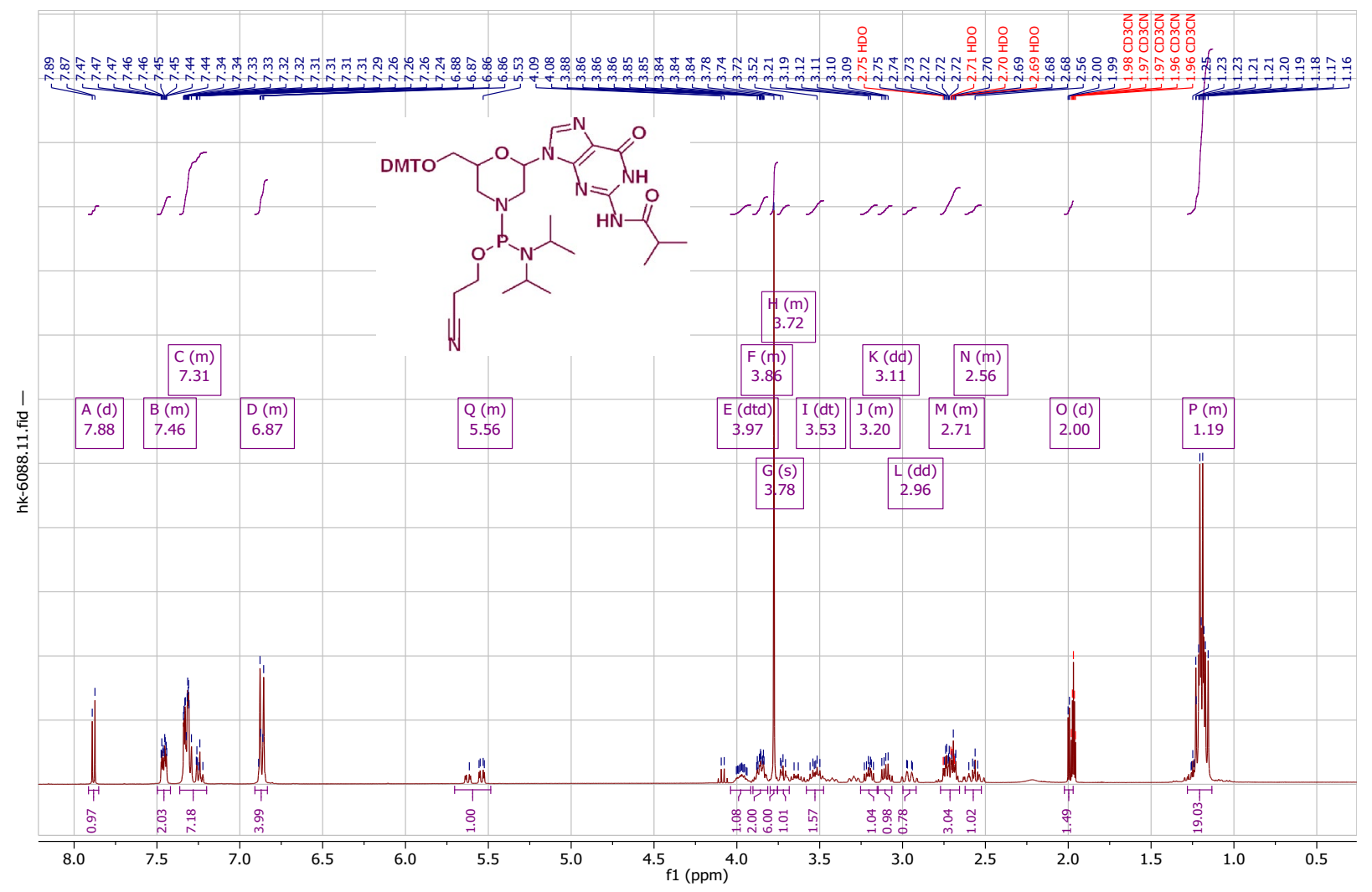

${ }^{1} \mathrm{H}$ NMR Spectrum $\left(400 \mathrm{MHz}, \mathrm{CD}_{3} \mathrm{CN}\right)$ of Compound $4 \mathrm{~b}$ 


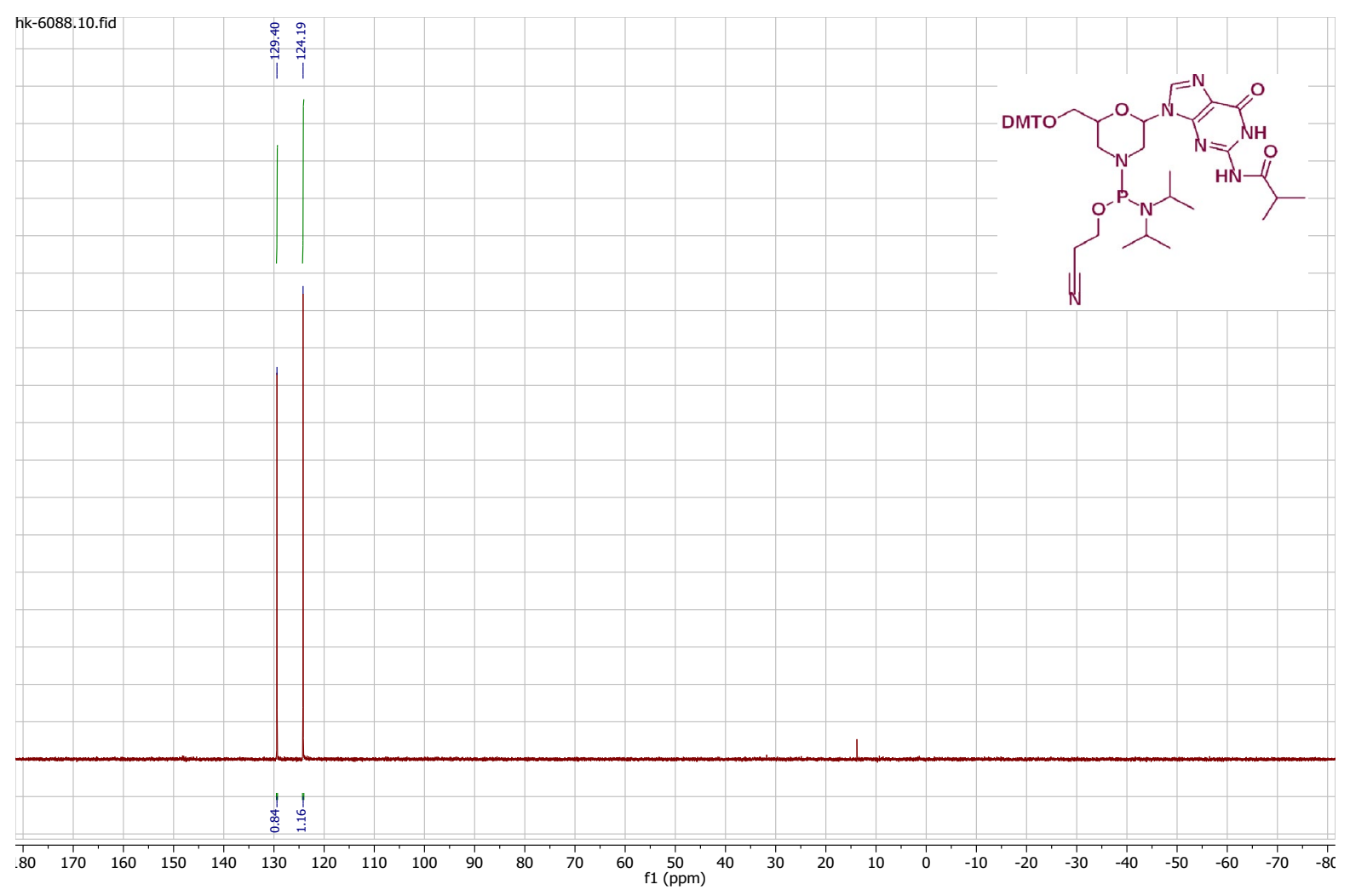

${ }^{31} \mathrm{P}\{1 \mathrm{H}\}$ NMR Spectrum (400 MHz, $\mathrm{CD}_{3} \mathrm{CN}$ ) of Compound $4 \mathrm{~b}$

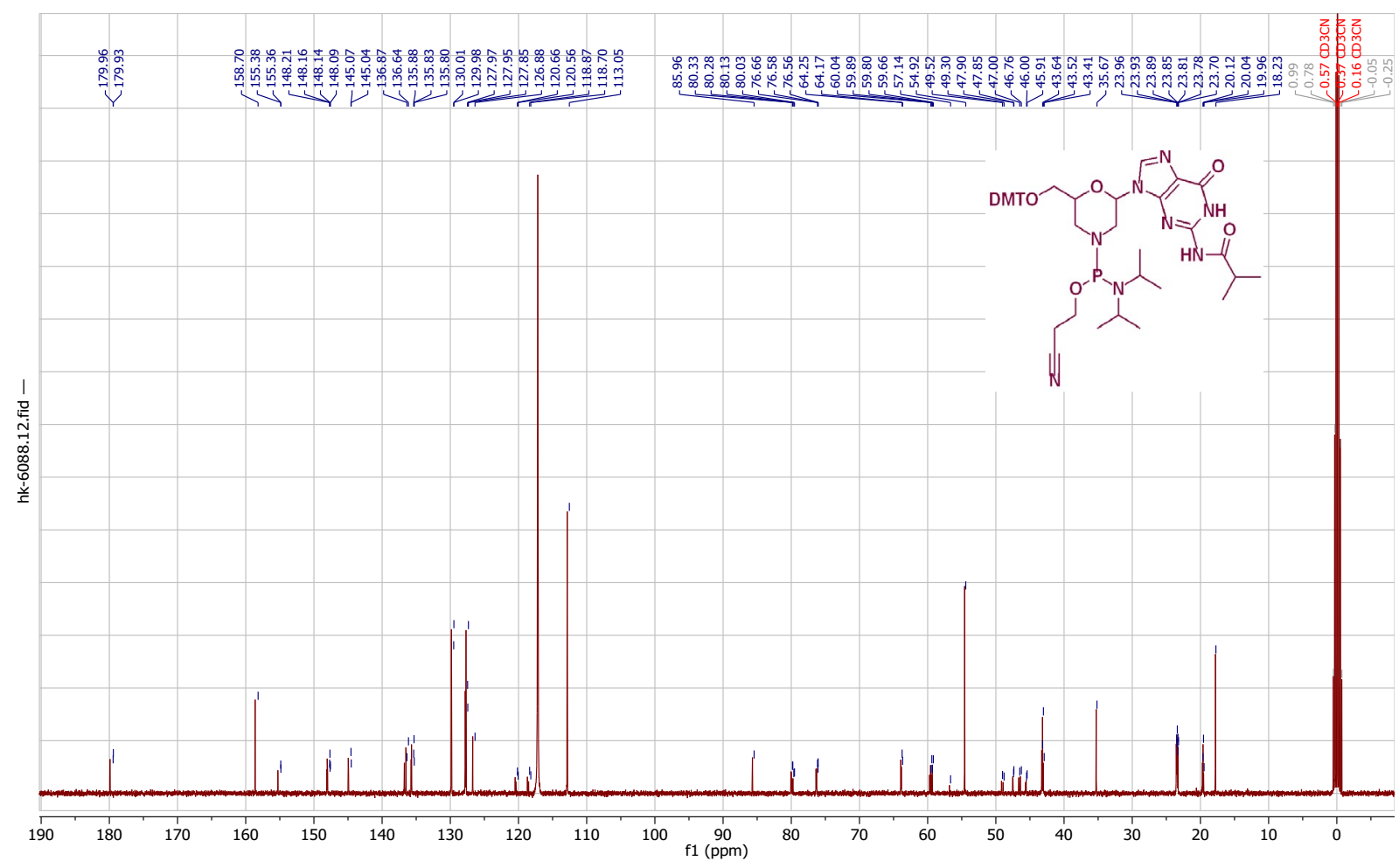

${ }^{13} \mathrm{C}$ NMR Spectrum (400 MHz, $\mathrm{CD}_{3} \mathrm{CN}$ ) of Compound $4 \mathrm{~b}$ 
Compound $4 \mathrm{~b}$ was prepared by following the general experimental procedure using morpholino nucleoside $3 \mathrm{~b}(3.07 \mathrm{~g}, 4.8 \mathrm{mmol}$ ), Bis(diisopropylamino)(2-cyanoethoxy)phosphine (1.2 equiv., $5.76 \mathrm{mmol}$, $1.83 \mathrm{~mL}$ ) and $0.25 \mathrm{M}$ 5-Ethylthio-1H-Tetrazole (0.5 equiv, $2.4 \mathrm{mmol}, 9.6 \mathrm{~mL}$ ) in anhydrous dichloromethane. ${ }^{1} \mathrm{H} \mathrm{NMR}\left(400 \mathrm{MHz}\right.$, Acetonitrile- $\left.\mathrm{d}_{3}\right) \delta 7.88(\mathrm{~d}, \mathrm{~J}=6.6 \mathrm{~Hz}, 1 \mathrm{H}), 7.50-7.42(\mathrm{~m}, 2 \mathrm{H}), 7.36-$ $7.20(\mathrm{~m}, 7 \mathrm{H}), 6.91-6.83(\mathrm{~m}, 4 \mathrm{H}), 5.70-5.49(\mathrm{~m}, 1 \mathrm{H}), 3.97(\mathrm{dtd}, \mathrm{J}=10.2,6.2,5.7,2.5 \mathrm{~Hz}, 1 \mathrm{H}), 3.90-3.81$ $(\mathrm{m}, 2 \mathrm{H}), 3.78(\mathrm{~s}, 6 \mathrm{H}), 3.75-3.68(\mathrm{~m}, 1 \mathrm{H}), 3.53(\mathrm{dt}, \mathrm{J}=10.1,6.7 \mathrm{~Hz}, 2 \mathrm{H}), 3.25-3.15(\mathrm{~m}, 1 \mathrm{H}), 3.11(\mathrm{dd}, \mathrm{J}=$ 9.7, $5.5 \mathrm{~Hz}, 1 \mathrm{H}), 2.96(\mathrm{dd}, \mathrm{J}=11.9,1.9 \mathrm{~Hz}, 1 \mathrm{H}), 2.77-2.66(\mathrm{~m}, 3 \mathrm{H}), 2.62-2.52(\mathrm{~m}, 1 \mathrm{H}), 2.00(\mathrm{~d}, \mathrm{~J}=3.1 \mathrm{~Hz}$, 1H), $1.28-1.13(\mathrm{~m}, 19 \mathrm{H}) .{ }^{13} \mathrm{C}$ NMR $\left(101 \mathrm{MHz}\right.$, Acetonitrile-d $\left.\mathrm{d}_{3}\right) \delta 179.96,179.93,158.70,155.38,155.36$, 148.21, 148.16, 148.14, 148.09, 145.07, 145.04, 136.87, 136.64, 135.88, 135.83, 135.80, 130.01, 129.98, $127.97,127.95,127.85,126.88,120.66,120.56,118.87,118.70,113.05,85.96,80.33,80.28,80.13,80.03$, 76.66, 76.58, 76.56, 64.25, 64.17, 60.04, 59.89, 59.80, 59.66, 57.14, 54.92, 49.52, 49.30, 47.90, 47.85, 47.00, 46.76, 46.00, 45.91, 43.64, 43.52, 43.41, 35.67, 23.96, 23.93, 23.89, 23.85, 23.81, 23.78, 23.70, 20.12, 20.04, 19.96, 18.23. ${ }^{31} \mathrm{P}$ NMR (162 MHz, Acetonitrile- $\left.d_{3}\right) \delta 129.40,124.19$. ESI calcd. for $\left[\mathrm{C}_{44} \mathrm{H}_{55} \mathrm{~N}_{8} \mathrm{O}\right.$ P P]: 838.3931, found $[\mathrm{M}+\mathrm{H}]^{+}: 839.4001$. Yield 4b: $2.37 \mathrm{~g}, 59 \%$.

Compound 4c: 6'-0-(4,4'-Dimethoxytrityl)-3'-O-cyanoethyl-1'-( $\mathbf{N}^{4}$-benzoylcytidine) morpholino(N,N'diisopropylamino) phosphorodiamidite.

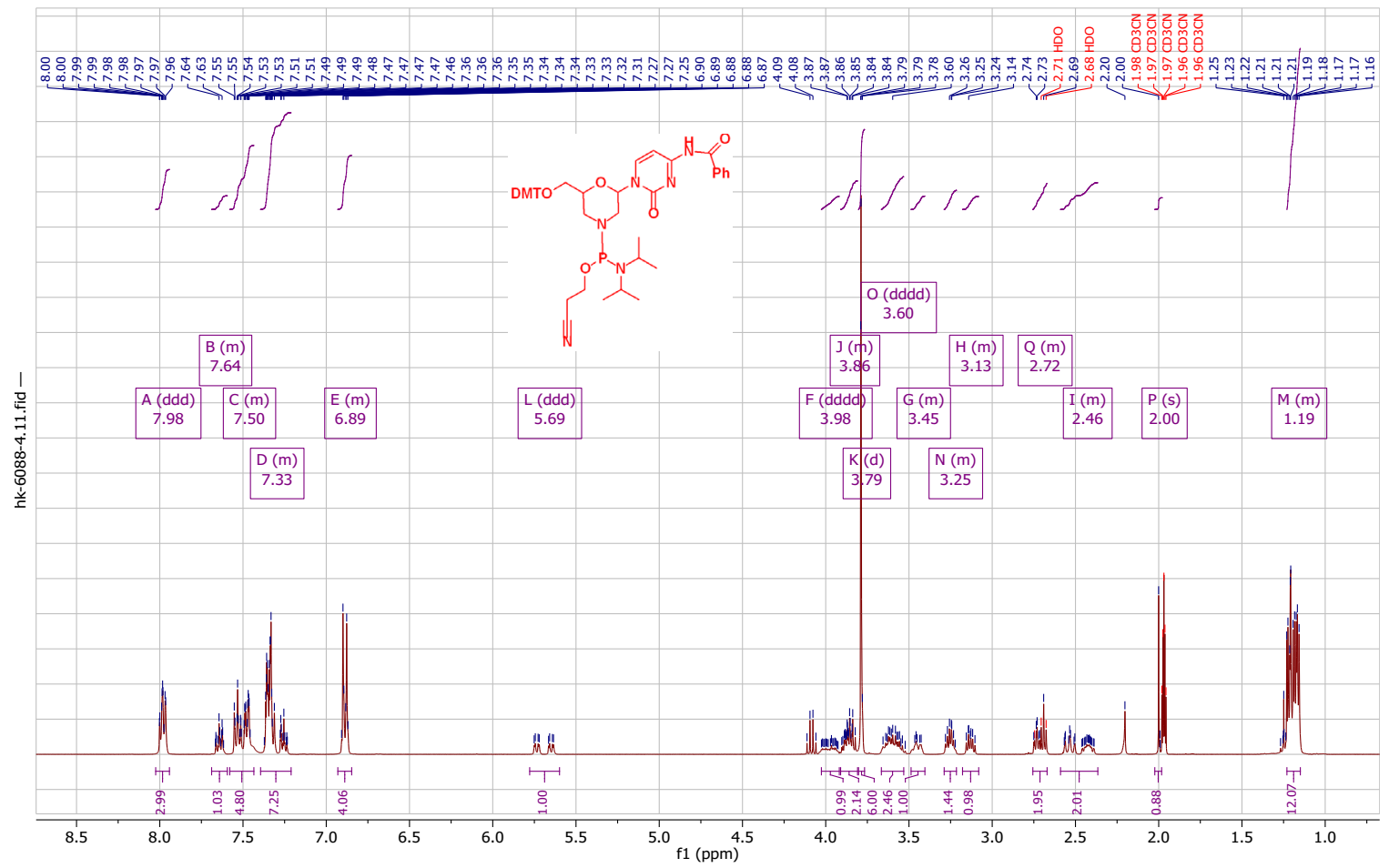

${ }^{1} \mathrm{H}$ NMR Spectrum $\left(400 \mathrm{MHz}, \mathrm{CD}_{3} \mathrm{CN}\right)$ of Compound $4 \mathrm{c}$ 


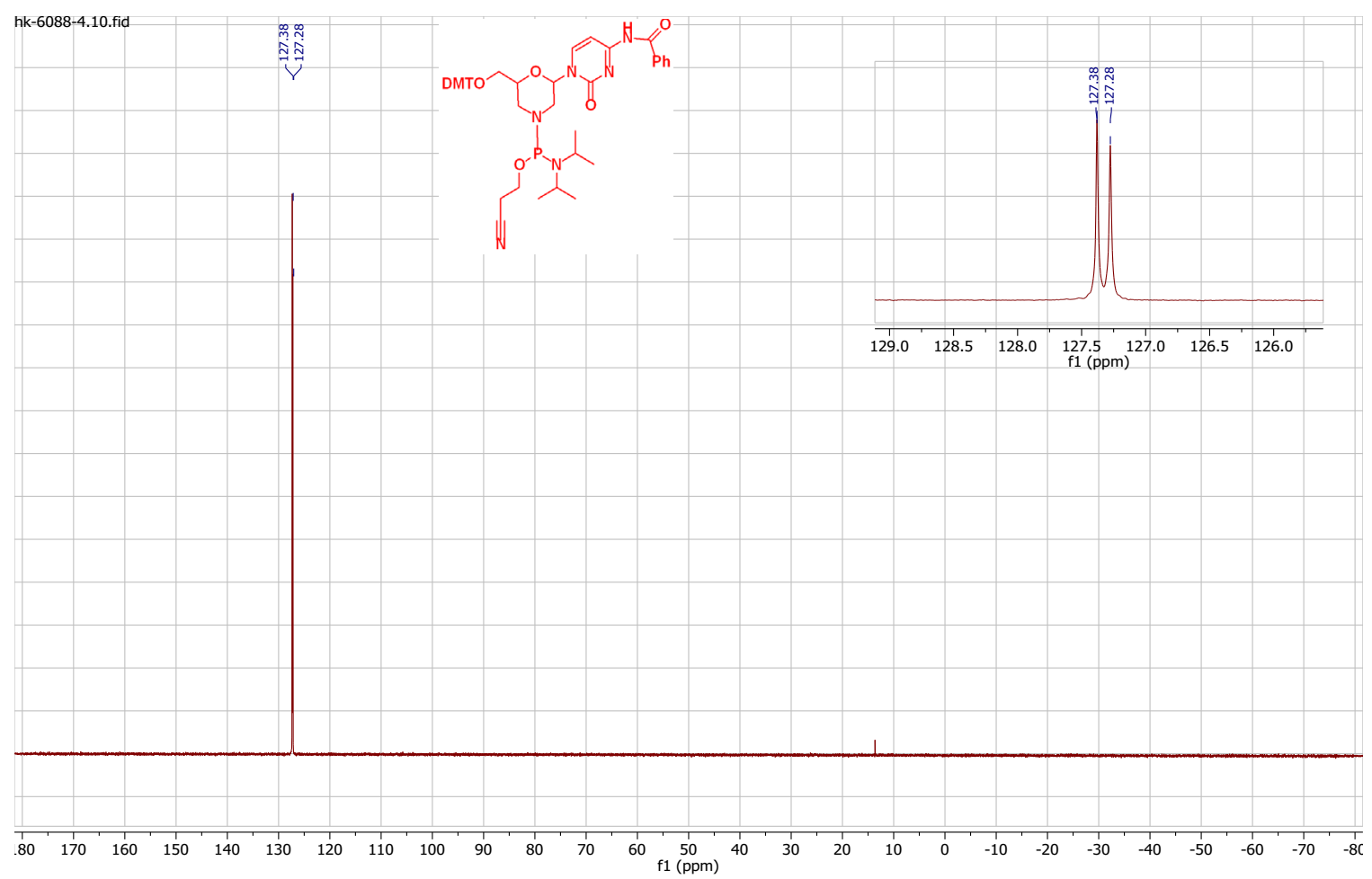

${ }^{31} \mathrm{P}\{1 \mathrm{H}\}$ NMR Spectrum (400 MHz, $\mathrm{CD}_{3} \mathrm{CN}$ ) of Compound 4c

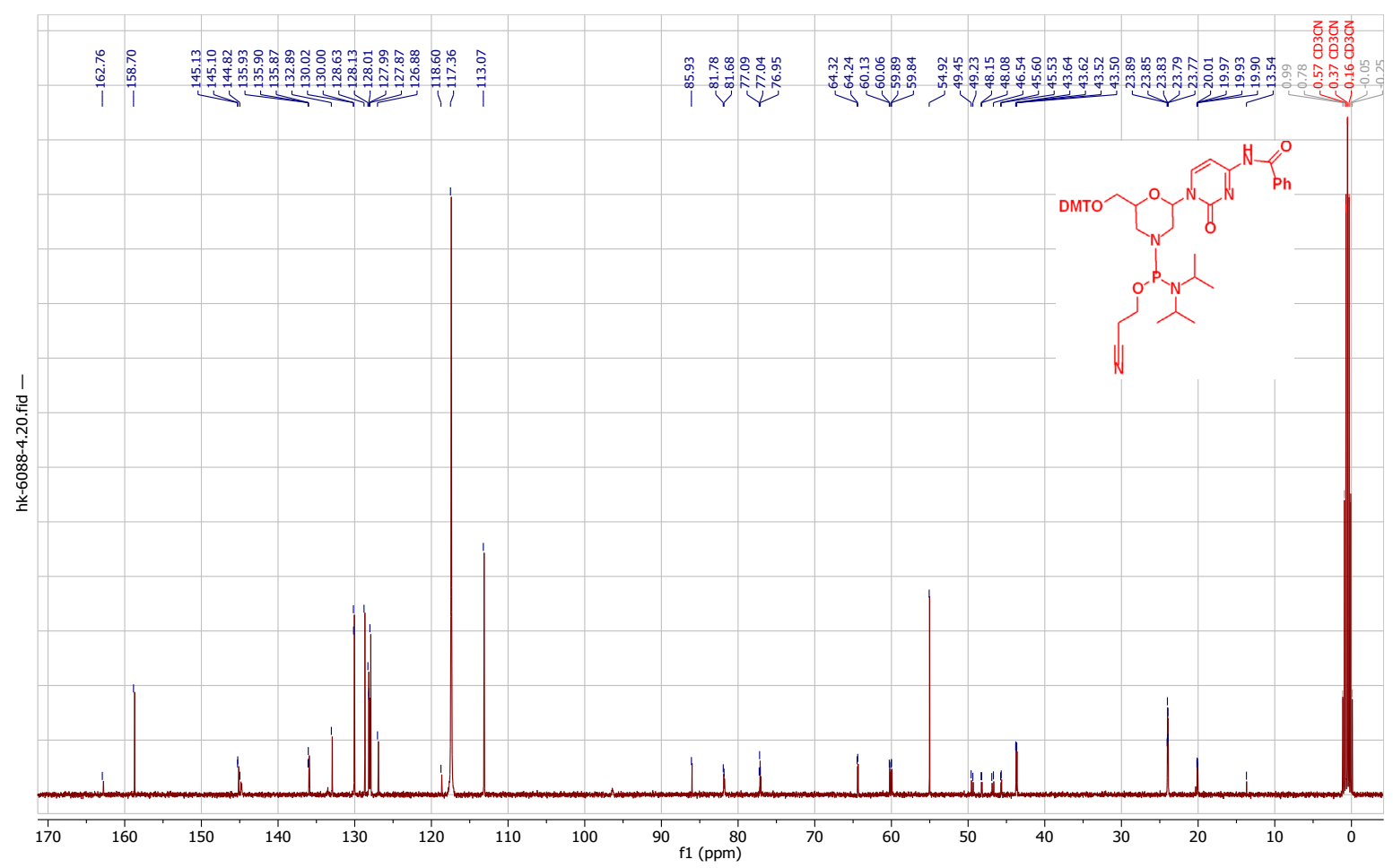

${ }^{13} \mathrm{C}$ NMR Spectrum (400 MHz, $\mathrm{CD}_{3} \mathrm{CN}$ ) of Compound $4 \mathrm{C}$ 
Compound $4 \mathrm{c}$ was prepared by following the general experimental procedure using morpholino nucleoside 3c (3.04 g, $4.8 \mathrm{mmol}$ ), Bis(diisopropylamino)(2-cyanoethoxy)phosphine (1.2 equiv., 5.76mmol, $1.83 \mathrm{~mL}$ ) and 0.25M 5-Ethylthio-1H-Tetrazole (0.5 equiv, $2.4 \mathrm{mmol}, 9.6 \mathrm{~mL}$ ) in dichloromethane. ${ }^{1} \mathrm{H}$ NMR (400 MHz, Acetonitrile-d3) $\delta 7.98$ (ddd, J = 8.7, 5.9, $1.2 \mathrm{~Hz}, 3 \mathrm{H}), 7.69-7.59(\mathrm{~m}, 1 \mathrm{H}), 7.58-7.43(\mathrm{~m}, 5 \mathrm{H})$, $7.39-7.21(\mathrm{~m}, 7 \mathrm{H}), 6.93-6.85(\mathrm{~m}, 4 \mathrm{H}), 5.69$ (ddd, J = 34.4, 9.4, 2.6 Hz, 1H), 3.98 (dddd, J = 21.1, 10.4, 5.2, $2.4 \mathrm{~Hz}, 1 \mathrm{H}), 3.91-3.81(\mathrm{~m}, 2 \mathrm{H}), 3.79(\mathrm{~d}, \mathrm{~J}=0.8 \mathrm{~Hz}, 6 \mathrm{H}), 3.60$ (dddd, J = 16.7, 13.6, 10.0, $6.6 \mathrm{~Hz}, 2 \mathrm{H}), 3.49$ $-3.40(\mathrm{~m}, 1 \mathrm{H}), 3.29-3.21(\mathrm{~m}, 1 \mathrm{H}), 3.18-3.08(\mathrm{~m}, 1 \mathrm{H}), 2.76-2.67(\mathrm{~m}, 2 \mathrm{H}), 2.59-2.37(\mathrm{~m}, 2 \mathrm{H}), 2.00(\mathrm{~s}$, 1H), $1.23-1.15$ (m, 12H). 13C NMR (101 MHz, Acetonitrile-d $\left.\mathrm{d}_{3}\right) \delta$ 162.76, 158.70, 145.13, 145.10, 144.82, 135.93, 135.90, 135.87, 133.48, 132.89, 130.02, 130.00, 128.63, 128.13, 128.01, 127.99, 127.87, 126.88, $118.60,117.36,113.07,85.93,81.78,81.68,77.09,77.04,76.95,64.32,64.24,60.13,60.06,59.99,59.89$, $59.84,54.92,49.45,49.23,48.15,48.08,46.76,46.54,45.60,45.53,43.64,43.62,43.52,43.50,23.89$, $23.85,23.83,23.79,23.77,20.19,20.01,19.97,19.93,19.90 .{ }^{31} \mathrm{P} \mathrm{NMR}\left(162 \mathrm{MHz}\right.$, Acetonitrile-d $\left.\mathrm{d}_{3}\right) \delta 127.38$, 127.28.ESI calcd. for $\left[\mathrm{C}_{46} \mathrm{H}_{53} \mathrm{~N}_{6} \mathrm{O}\right.$ P $\left.\mathrm{P}\right]: 832.3713$; found $[\mathrm{M}+\mathrm{H}]^{+}:$833.3793. Yield 4c: $2.63 \mathrm{~g}, 66 \%$

\section{Compound 4d: 6'-O-(4,4'-Dimethoxytrityl)-3'-O-cyanoethyl-1'-( $\mathbf{N}^{1}$-thymidine) morpholino(N, $\mathrm{N}^{\prime}$ - diisopropylamino) phosphorodiamidite.}

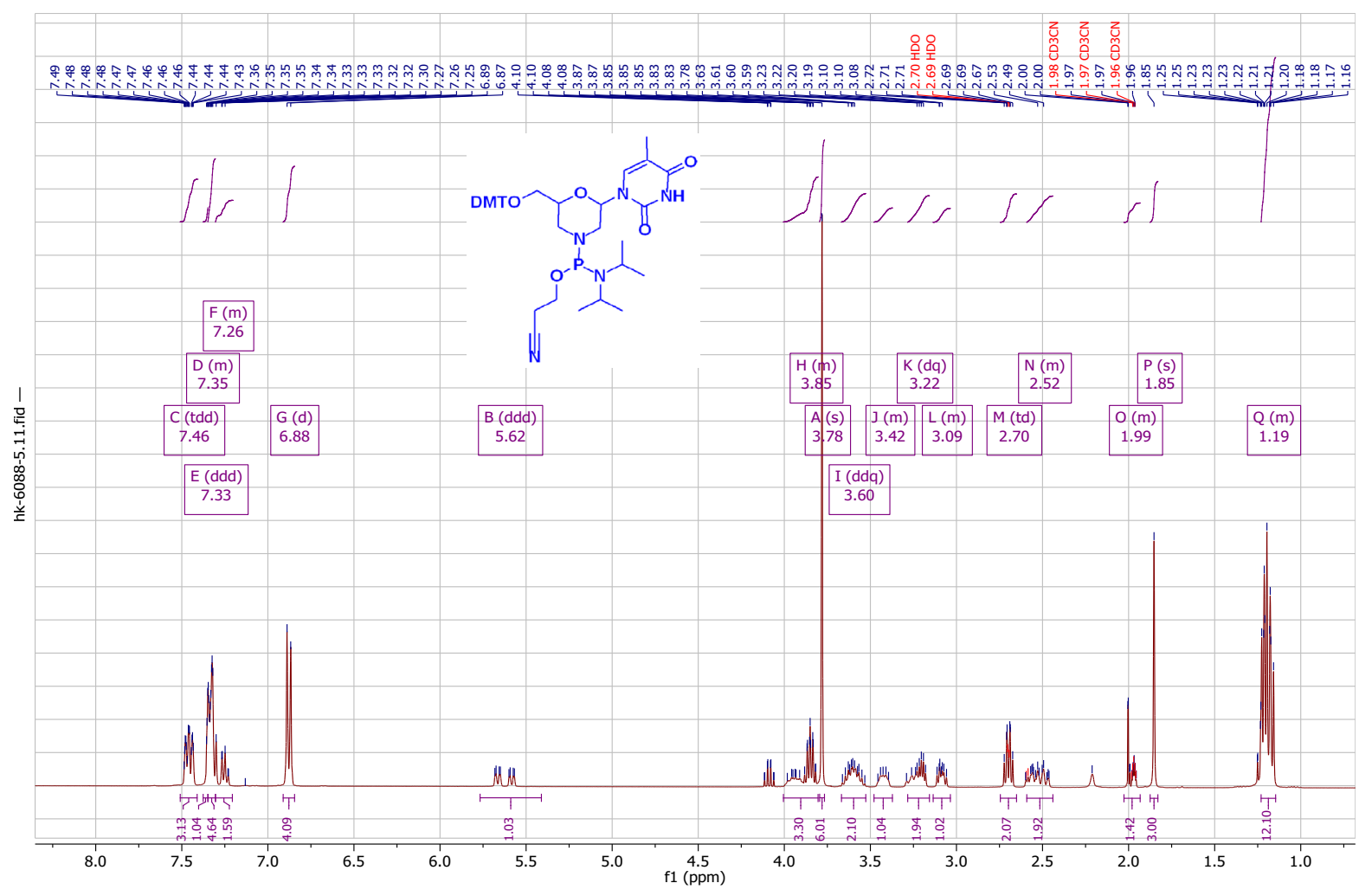

${ }^{1} \mathrm{H}$ NMR Spectrum $\left(400 \mathrm{MHz}, \mathrm{CD}_{3} \mathrm{CN}\right)$ of Compound $4 \mathrm{~d}$ 


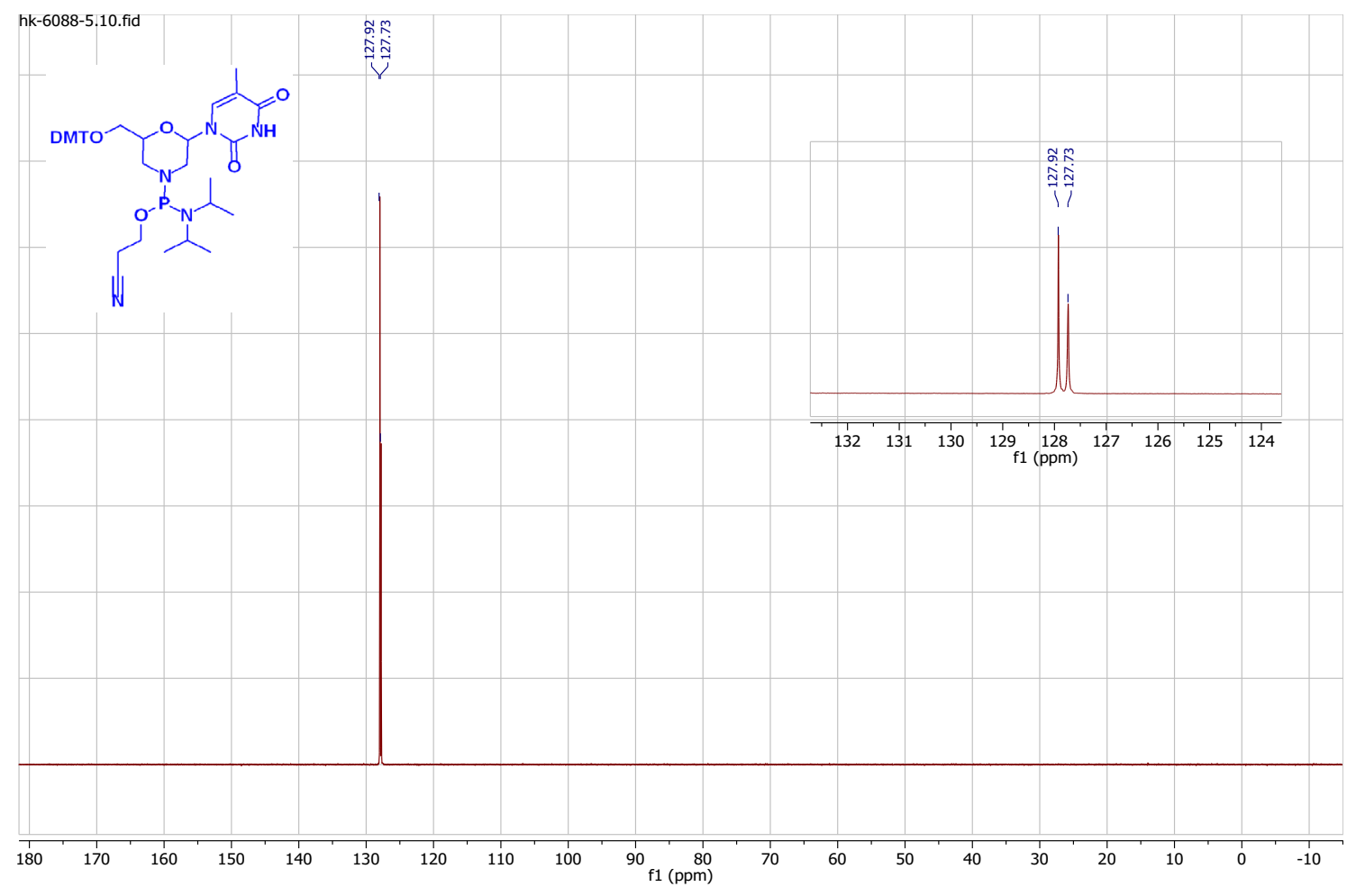

${ }^{31} \mathrm{P}\{1 \mathrm{H}\}$ NMR Spectrum (400 MHz, $\mathrm{CD}_{3} \mathrm{CN}$ ) of Compound $4 \mathrm{~d}$

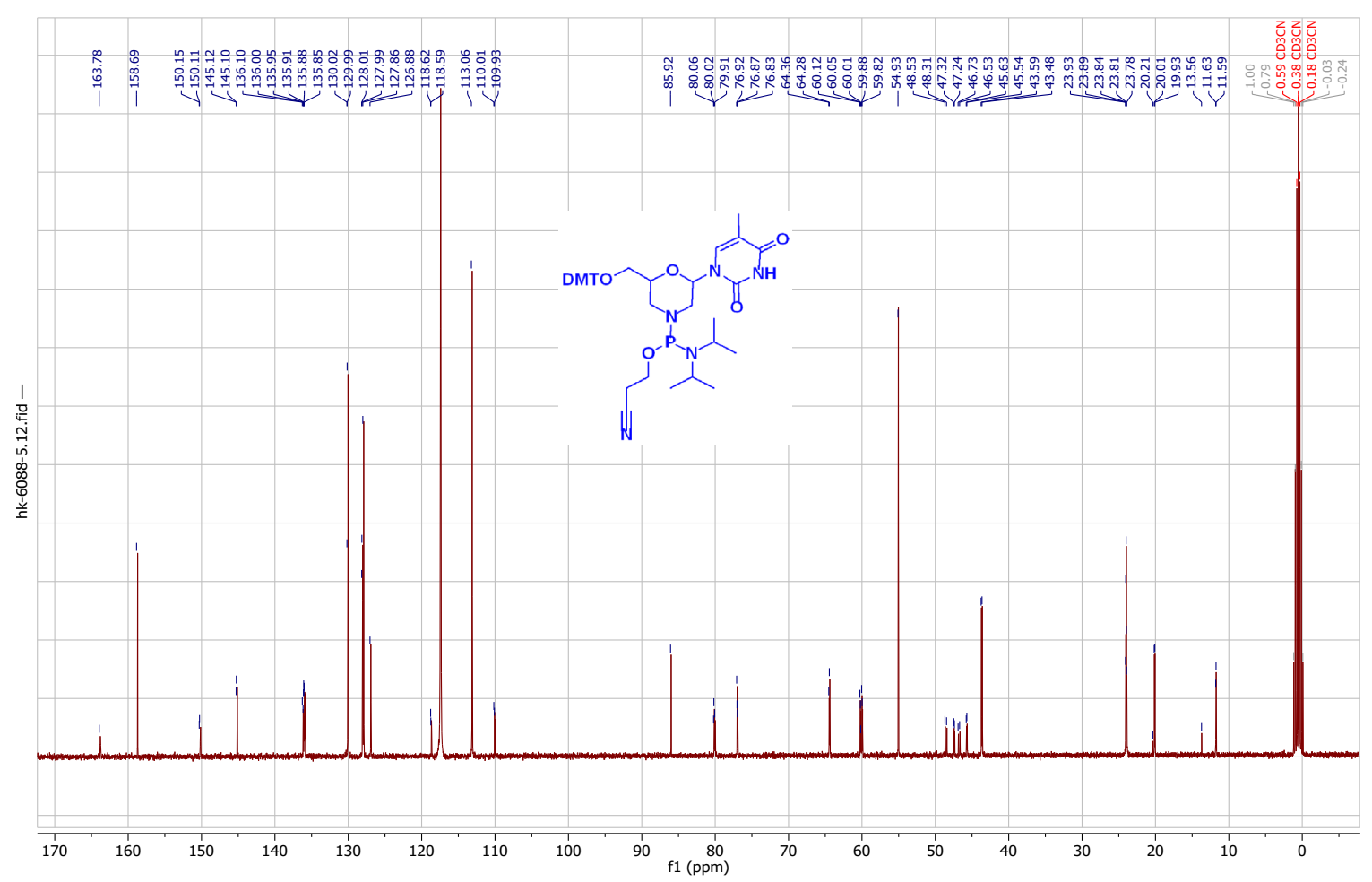

${ }^{13} \mathrm{C}$ NMR Spectrum (400 MHz, $\mathrm{CD}_{3} \mathrm{CN}$ ) of Compound $4 \mathrm{~d}$ 
Compound $4 \mathrm{~d}$ was prepared by following the general experimental procedure using morpholino nucleoside $3 \mathrm{~d}$ ( $2.61 \mathrm{~g}, 4.8 \mathrm{mmol}$ ), Bis(diisopropylamino)(2-cyanoethoxy)phosphine (1.2 equiv., 5.76mmol, $1.83 \mathrm{~mL}$ ) and $0.25 \mathrm{M}$ 5-Ethylthio-1H-Tetrazole (0.5 equiv, $2.4 \mathrm{mmol}, 9.6 \mathrm{~mL}$ ) in anhydrous dichloromethane. ${ }^{1} \mathrm{H}$ NMR $\left(400 \mathrm{MHz}\right.$, Acetonitrile- $\left.\mathrm{d}_{3}\right) \delta 7.46$ (tdd, J = 8.8, 2.8, $\left.1.6 \mathrm{~Hz}, 3 \mathrm{H}\right), 7.38-7.35$ (m, $1 \mathrm{H}$ ), 7.33 (ddd, J = 5.6, 2.9, $1.3 \mathrm{~Hz}, 5 \mathrm{H}), 7.30-7.21(\mathrm{~m}, 2 \mathrm{H}), 6.88(\mathrm{~d}, \mathrm{~J}=8.5 \mathrm{~Hz}, 4 \mathrm{H}), 5.62$ (ddd, J = 32.6, 9.9, $2.7 \mathrm{~Hz}, 1 \mathrm{H}), 4.01-3.80(\mathrm{~m}, 3 \mathrm{H}), 3.78(\mathrm{~s}, 6 \mathrm{H}), 3.60(\mathrm{ddq}, \mathrm{J}=16.9,13.8,6.8 \mathrm{~Hz}, 2 \mathrm{H}), 3.48-3.37(\mathrm{~m}, 1 \mathrm{H}), 3.22$ $(\mathrm{dq}, \mathrm{J}=9.9,7.0,5.0 \mathrm{~Hz}, 2 \mathrm{H}), 3.14-3.04(\mathrm{~m}, 1 \mathrm{H}), 2.70(\mathrm{td}, \mathrm{J}=6.6,5.6 \mathrm{~Hz}, 2 \mathrm{H}), 2.59-2.44(\mathrm{~m}, 2 \mathrm{H}), 2.03-$ $1.93(\mathrm{~m}, 1 \mathrm{H}), 1.85(\mathrm{~s}, 3 \mathrm{H}), 1.23-1.15(\mathrm{~m}, 12 \mathrm{H}) .{ }^{13} \mathrm{C} \mathrm{NMR}\left(101 \mathrm{MHz}\right.$, Acetonitrile-d $\left.\mathrm{d}_{3}\right) \delta 163.78,158.69$, $150.15,150.11,145.12$, 145.10, 136.10, 136.00, 135.95, 135.91, 135.88, 135.85, 130.02, 129.99, 128.01, 127.99, 127.86, 126.88, 118.62, 118.59, 113.06, 110.01, 109.93, 85.92, 80.06, 80.02, 79.91, 76.92, 76.87, 76.83, 64.36, 64.28, 60.12, 60.05, 60.01, 59.88, 59.82, 54.93, 48.53, 48.31, 47.32, 47.24, 46.73, 46.53, $45.63,45.54,43.59,43.48,23.93,23.89,23.84,23.81,23.78,20.21,20.01,19.93,13.56,11.63,11.59 .{ }^{31} \mathrm{P}$ NMR $\left(162 \mathrm{MHz}\right.$, Acetonitrile- $\left.\mathrm{d}_{3}\right) \delta 127.92$, 127.73. ESI calcd. for $\left[\mathrm{C}_{40} \mathrm{H}_{50} \mathrm{~N}_{5} \mathrm{O} \mathrm{P}\right]: 743.3448$, found $[\mathrm{M}+\mathrm{H}]^{+}: 744.3528$ Yield 4d: $2.93 \mathrm{~g}, 82 \%$.

\section{Solid-Phase Synthesis of TMO and TMO-DNA-pS Chimeras}

In order to synthesize TMOs and TMO-DNA-pS chimeras, the 5'-DMT group of the 2'-deoxyribonucleoside or the universal linker attached to the solid-support (CPG-500 support or Universal Support III, Glen Research) was removed using deblock reagent (3\% trichloroacetic acid in dichloromethane). This was reacted with $6^{\prime}$-DMT-morpholinonucleoside-3'-phosphorodiamidites of $\mathrm{mA}^{\mathrm{Bz}}, \mathrm{mG}^{\mathrm{iBu}}, \mathrm{mC}^{\mathrm{Bz}}$, or $\mathrm{mT}$ in the presence of $0.12 \mathrm{M} \mathrm{ETT} \mathrm{in} \mathrm{anhydrous} \mathrm{acetonitrile} \mathrm{with} \mathrm{a} 600 \mathrm{~s}$ condensation time. In the case of the TMODNA-pS chimeras, a 30 second condensation time was used for coupling the commercially available 2'deoxyribonucleotide $3^{\prime}$-phosphoramidites. In all cases, the nascent $\mathrm{P}$ (III) linkage was converted to thiophosphoramidate morpholino (TMO) or 2'-deoxyribonucleotide phosphorothioate by sulfurization using 3-[(Dimethylaminomethylene)amino]-3H-1,2,4-dithiazole-5-thione (DDTT, 360s). Following sulfurization, conventional capping reagents (Cap A: Tetrahydrofuran/Acetic Anhydride and Cap B: 16\% 1Methylimidazole in Tetrahydrofuran; Glen Research) were used to acetylate any unreacted hydroxyl groups. Subsequent detritylation followed by repetitive synthesis cycles generated oligonucleotides with exclusively TMO linkages or TMO-DNA-pS chimeras. Synthesis cycles were repeated until an oligonucleotide of the desired length and sequence was generated.

While using Universal Support III, the first morpholino phosphorodiamidite coupling step was followed by oxidation instead of sulfurization (USIII to S2, Figure 2, main text). All subsequent synthesis cycles were carried out as described for synthesis using CPG-500 supports.

Cleavage, Purification and Isolation of Oligonucleotides: Oligonucleotide cleavage from the support and removal of base and phosphorus protecting groups were carried out using $28 \%$ aqueous ammonia at 55 ${ }^{\circ} \mathrm{C}$ for $18 \mathrm{~h}$ (for Universal Support III, $2 \mathrm{M}$ ammonia/methanol, $60 \mathrm{~min}$ followed by $28 \%$ aqueous. ammonia, $55^{\circ} \mathrm{C}, 16 \mathrm{~h}$ was used). Following this step, the ammonia solution was evaporated, and the solids dissolved in $3 \%$ aqueous methanol, filtered ( 0.2 -micron filter) to remove insoluble residues, and the product mixture analyzed by LCMS. The crude oligonucleotide mixture (1.0 $\mu \mathrm{M}$ synthesis scale) was redissolved in $3 \%$ aqueous acetonitrile and purified by ion-pair RP-HPLC using the DMT group as a lipophilic handle for the separation of the full-length product from shorter sequences $(3-100 \%$ gradient of Eluent $B$ (acetonitrile) in aqueous $50 \mathrm{mM}$ triethylammonium bicarbonate (Buffer A); $2 \mathrm{~mL}$ flow rate as described in $\mathrm{SI}$ section1. The DMT protected oligonucleotide was isolated in pure form. After evaporating the pooled 
fractions of this product to dryness, it was treated with $500 \mu \mathrm{L}$ of $50 \%$ aqueous acetic acid to remove the DMT group. After vortexing at room temperature for $5 \mathrm{~min}$, the acetic acid -oligonucleotide mixture was cooled in an ice bath following which the reaction mixture was neutralized with $300 \mu \mathrm{L}$ triethylamine. After evaporating to dryness, the detritylated oligonucleotide was purified using ion-pair RP-HPLC (Buffer A: $50 \mathrm{mM}$ aqueous triethylammonium bicarbonate; Buffer B: acetonitrile). The pure product fractions were combined and evaporated to dryness. All fluorescein labeled ODNs in Table 1 were synthesized using 5 'fluorescein phosphoramidite during the last condensation step followed by sulfurization using DDTT. These oligonucleotides were purified by semi-preparative scale RP-HPLC using the 50mM TEABacetonitrile buffer system. Desalting was carried out using NAP DNA purification columns (GE Healthcare).

\section{LCMS Analysis of Oligonucleotides}

LCMS data was collected on an Agilent 6530 series Q-TOF LCMS spectrometer using Waters ACQUITY UPLC $^{\circledast}$ BEH C18 column. Buffer A (aqueous phase) consisted of a combination of $2.5 \mathrm{~mL}$ triethylamine (TEA) and $26 \mathrm{~mL}$ hexafluoro-2-propanol (HFIP) in $97.5 \%$ water and $2.5 \%$ methanol (1L total volume). Organic mobile phase (Buffer B) consisted of $2.5 \mathrm{~mL}$ TEA and $26 \mathrm{~mL} \mathrm{HFIP} \mathrm{in} 92 \%$ methanol and $5 \%$ water (1L total volume). A gradient of $0-100 \%$ of Buffer B in 40 min, followed by $100 \%$ B for 15 minutes was used. The flow rate was $0.2 \mathrm{~mL} / \mathrm{min}$ at a set temperature of $25^{\circ} \mathrm{C}$. The observed masses of all TMOs and TMO-DNA-pS chimeras discussed in this paper correspond to the expected theoretical masses as listed in Table 1 and percentage yields are given in Table S1, p.S21. For ON containing a DMT label, the yields were calculated based on UV integration of full length DMT-ON product versus failures in the total reaction mixtures. In the case of fluorescently labeled ONs, the yields after HPLC purification (OD units) are provided below. 


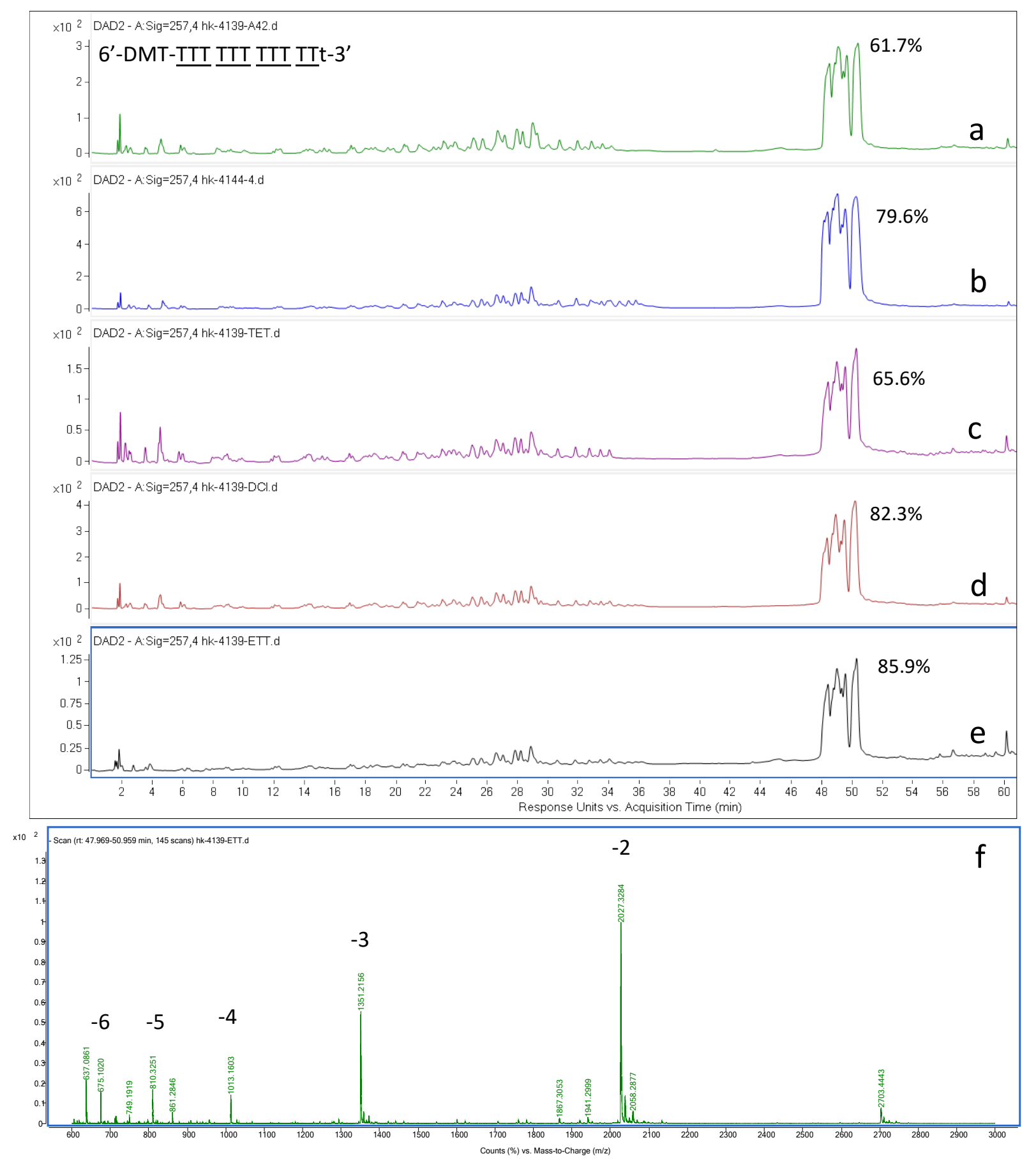

Figure S1. Comparison of the Solid-Phase Synthesis of TMO1 Using Different Activators. Figure S1(a-e): LCMS-UV profiles of total reaction mixtures from solid phase oligonucleotide synthesis using (a) $0.12 \mathrm{M}$ Activator 42® (b) $0.12 \mathrm{M}$ ETT buffered with $0.01 \mathrm{M}$ DMAP (c) $0.20 \mathrm{M}$ Tetrazole (d) $0.12 \mathrm{M}$ 4,5Dicyanoimidazole (e) $0.12 \mathrm{M}$ 5-Ethylthio-1H-Tetrazole. (f) $\mathrm{m} / \mathrm{z}$ analysis of TMO1 when synthesized using 0.12 M ETT (Figure S1(e), Rt = 48-51 min.). 


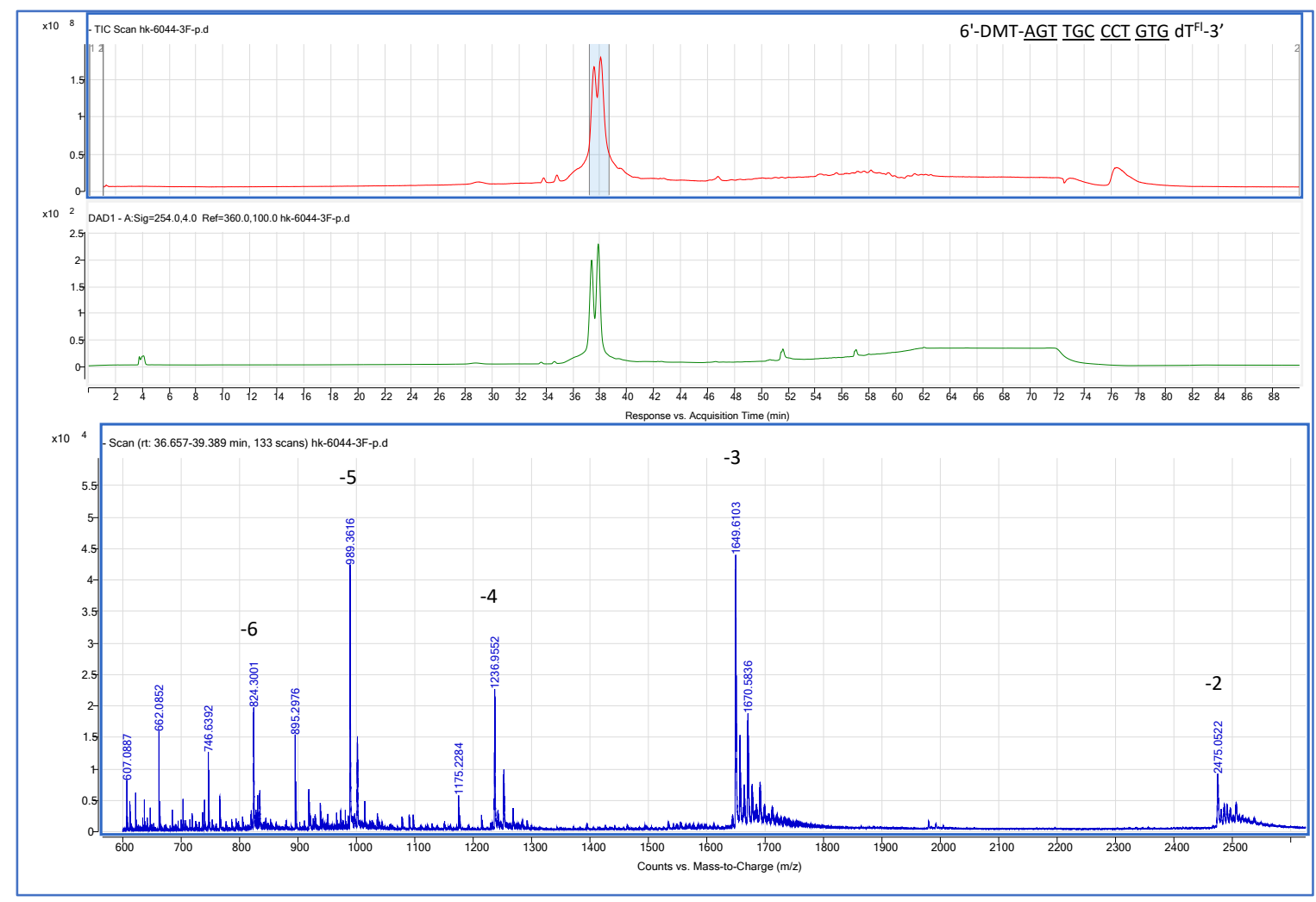

Figure S2. LCMS UV Profile and Mass Characterization of RP-HPLC Purified TMO2.

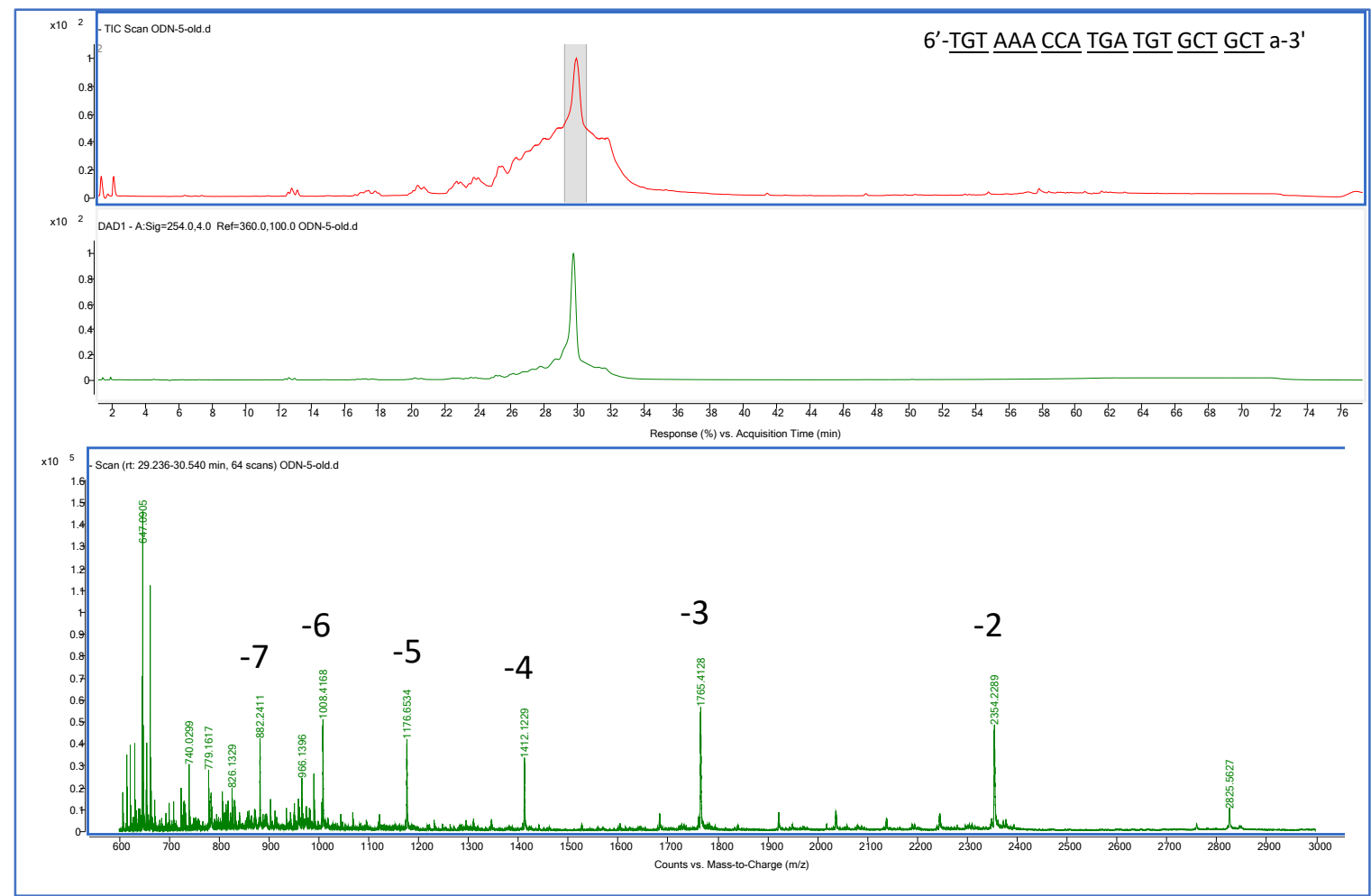

Figure S3. LCMS UV Profile and Mass Characterization of RP-HPLC Purified TMO3. 


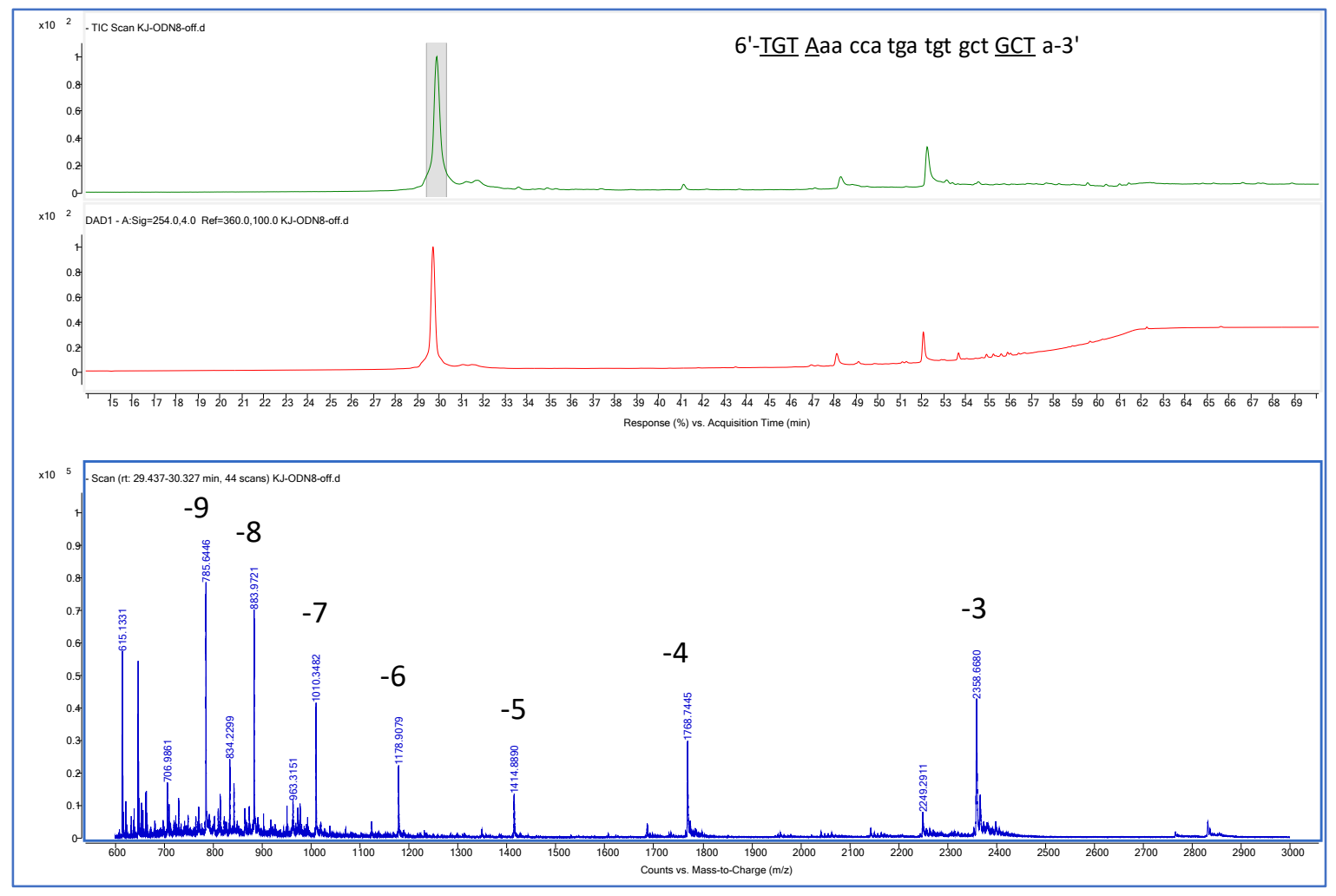

Figure S4. LCMS UV Profile and Mass Characterization of RP-HPLC Purified TMO-DNA-pS Chimera 4.

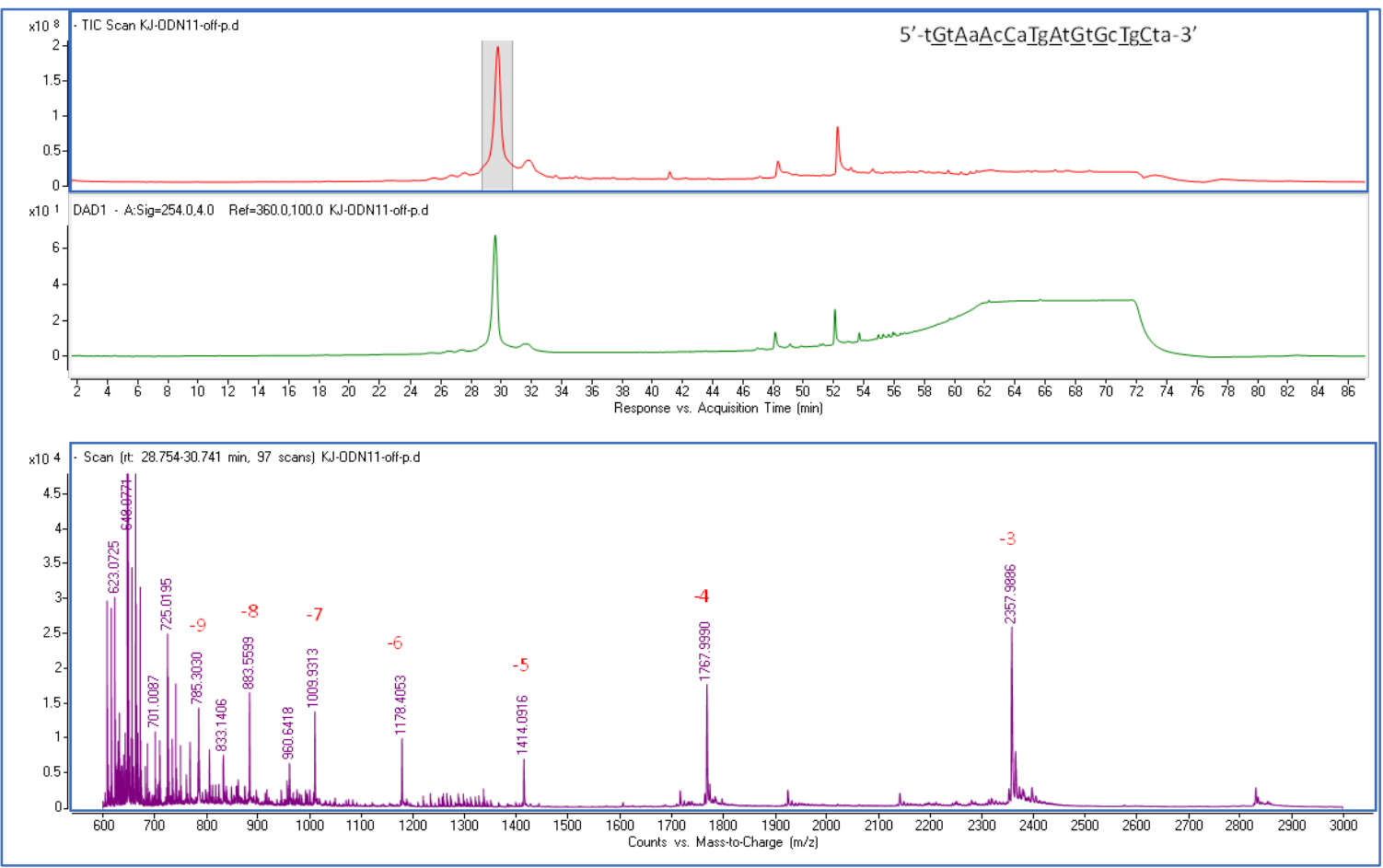

Figure S5. LCMS UV Profile and Mass Characterization of RP-HPLC Purified TMO-DNA-pS Chimera 5. 


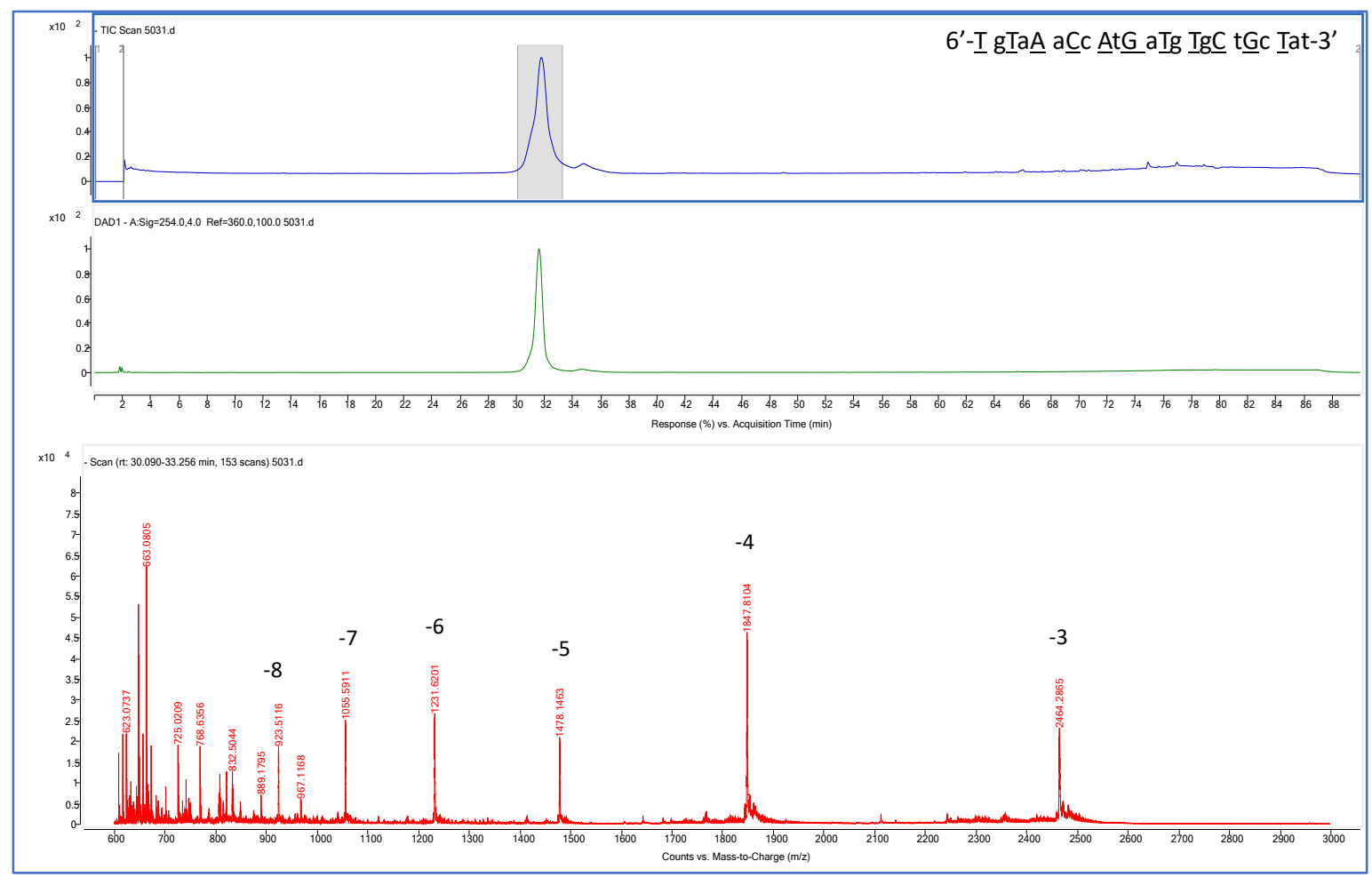

Figure S6. LCMS UV Profile and Mass Characterization of RP-HPLC Purified TMO-DNA-pS Chimera 6
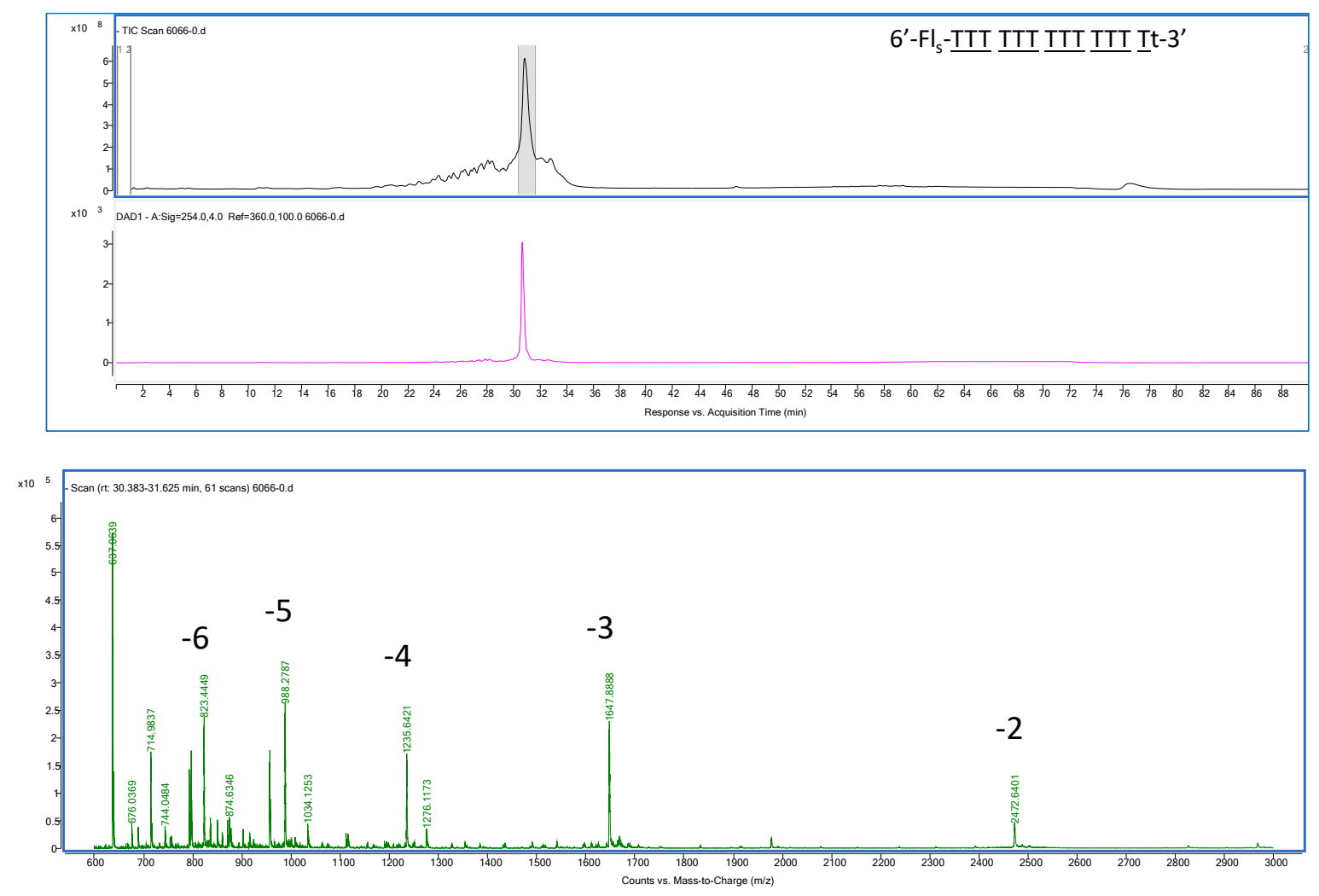

Figure S7. LCMS UV Profile and Mass Characterization of RP-HPLC Purified TMO7. 


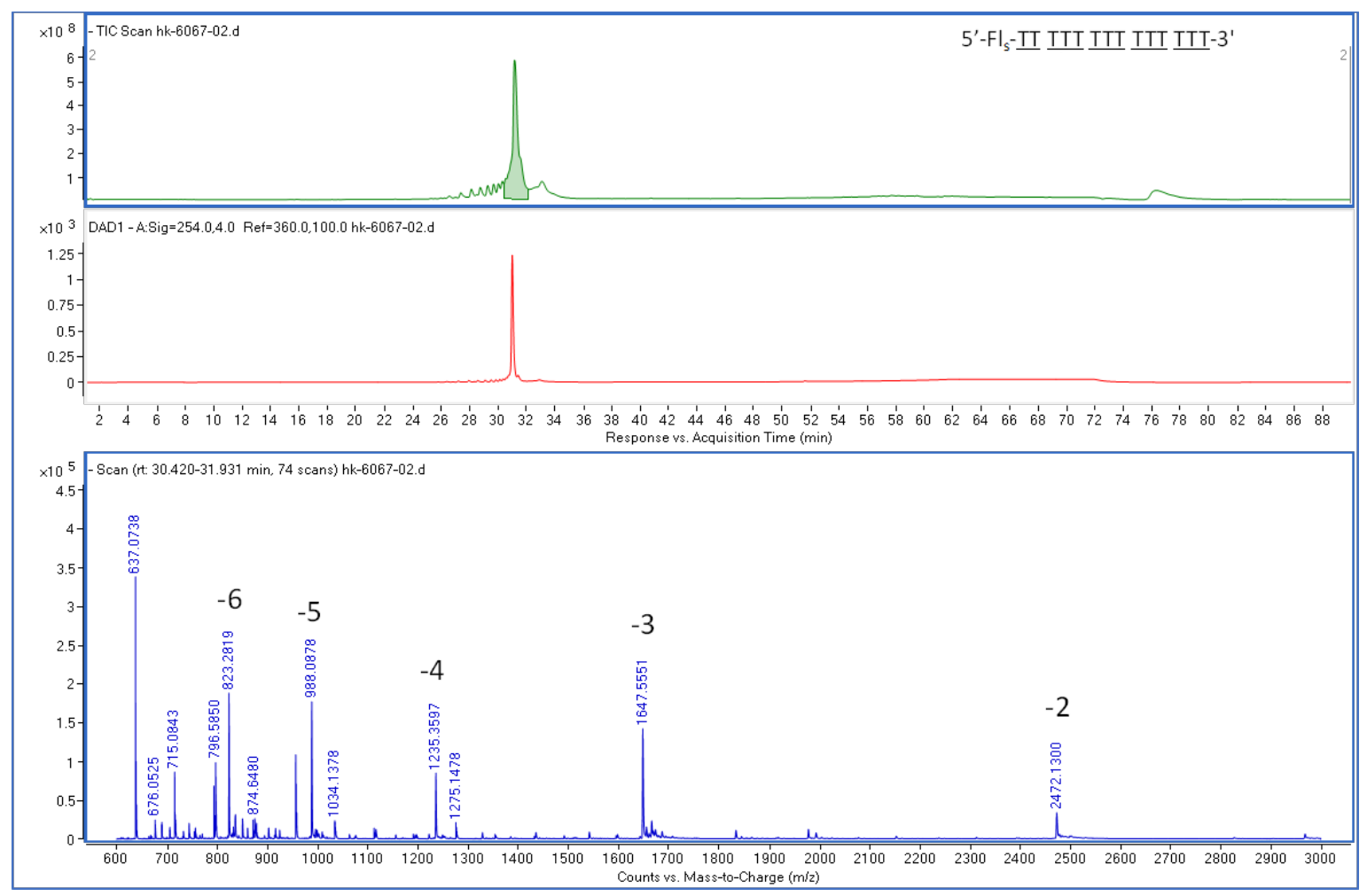

Figure S8. LCMS UV Profile and Mass Characterization of RP-HPLC Purified TMO8.

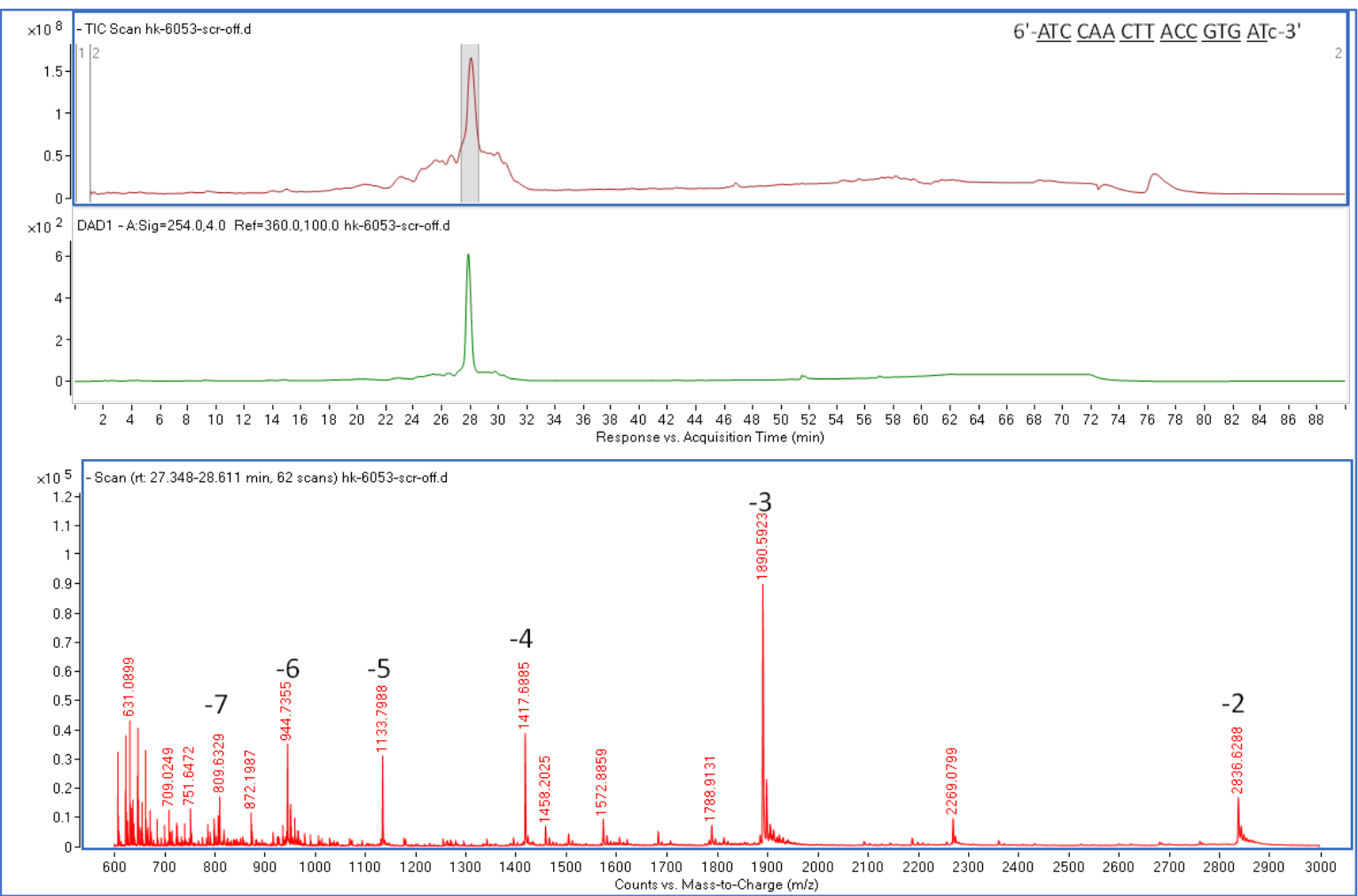

Figure S9. LCMS UV Profile and Mass Characterization of RP-HPLC Purified TMO9. 


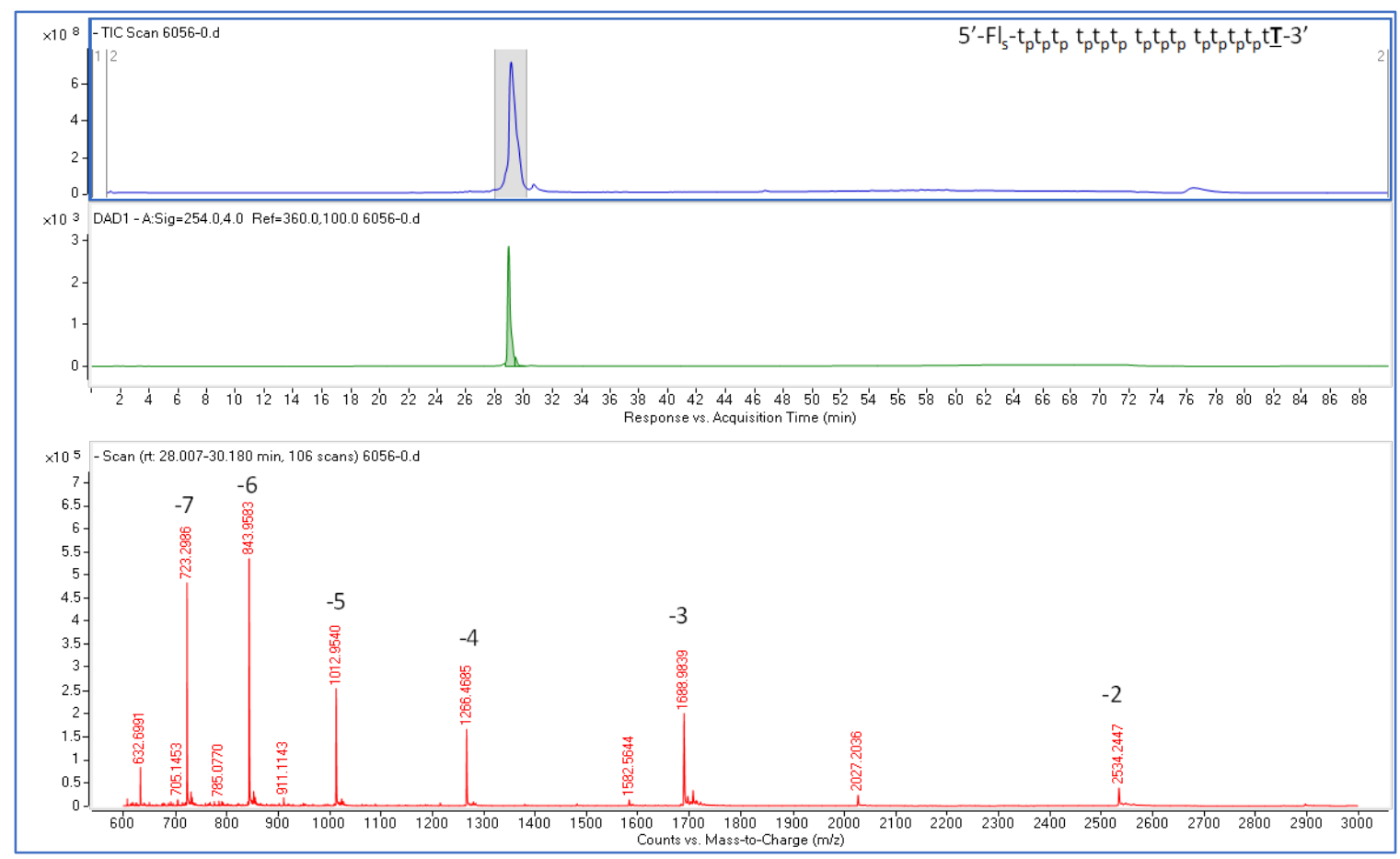

Figure S10. LCMS UV Profile and Mass Characterization of RP-HPLC Purified TMO 10.

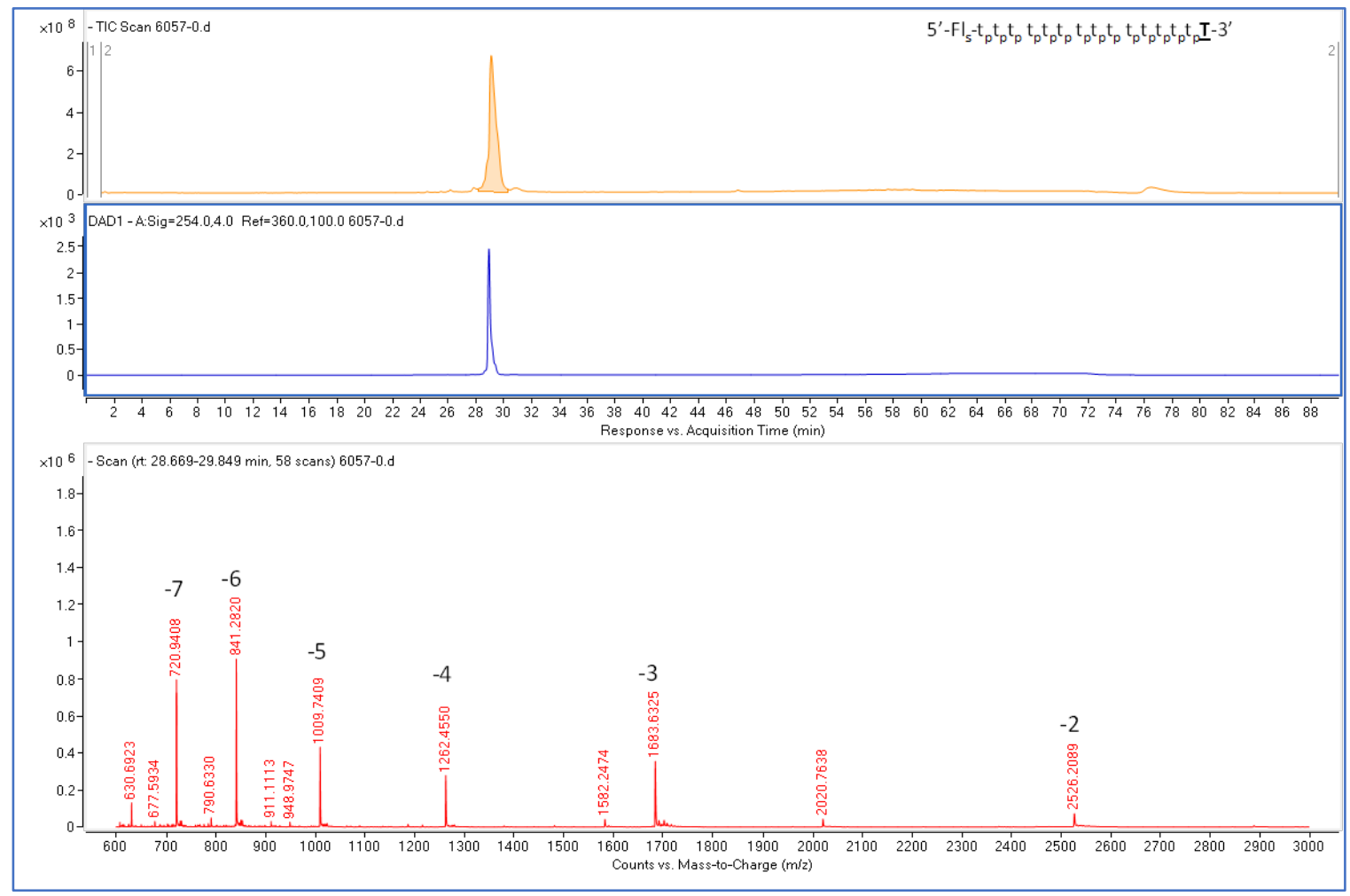

Figure S11. LCMS UV Profile and Mass Characterization of RP-HPLC Purified TMO11. 

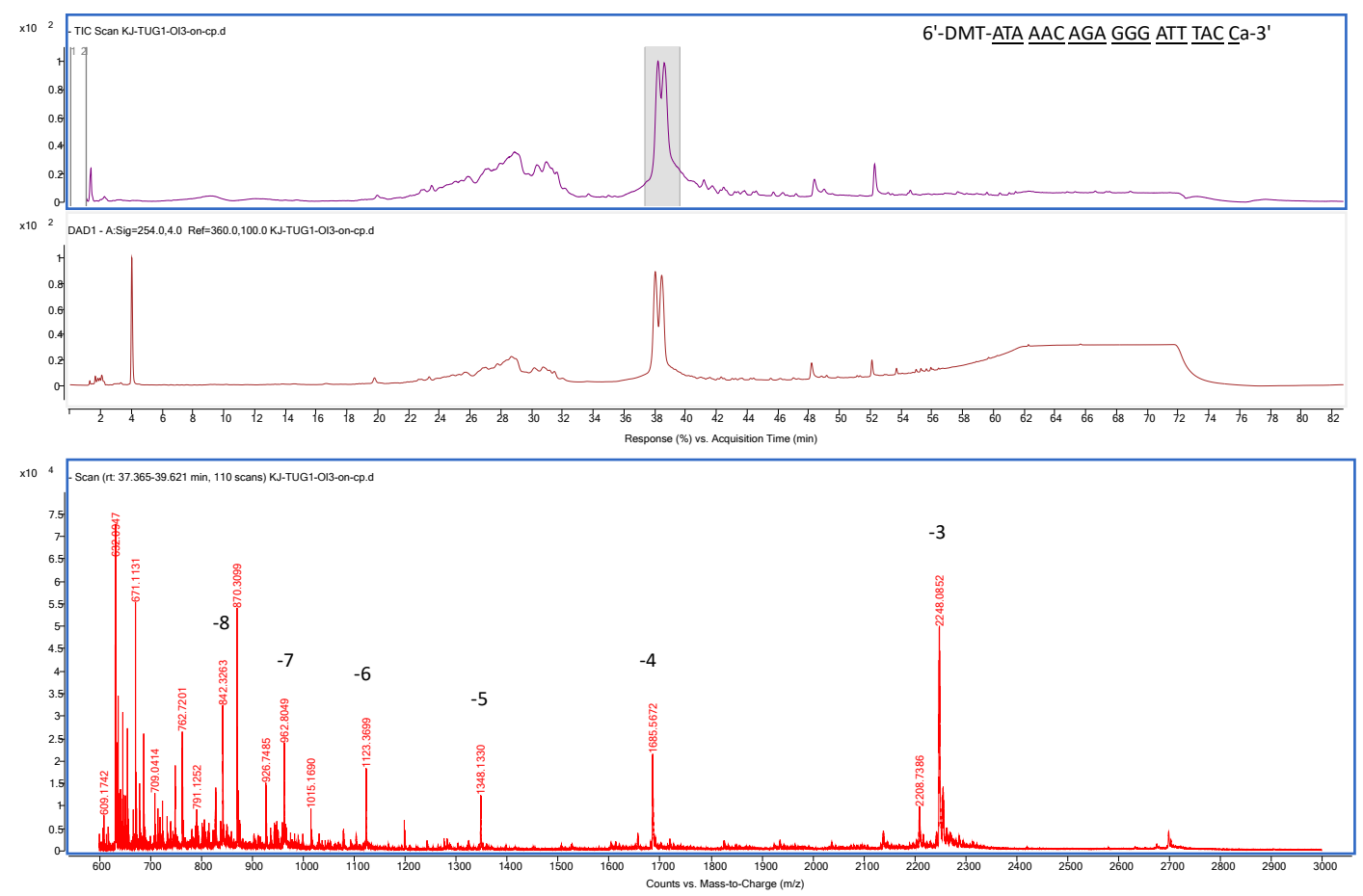

Figure S12(a). LCMS UV Profile and Mass Characterization of the crude reaction mixture of 6'-DMT TMO14.

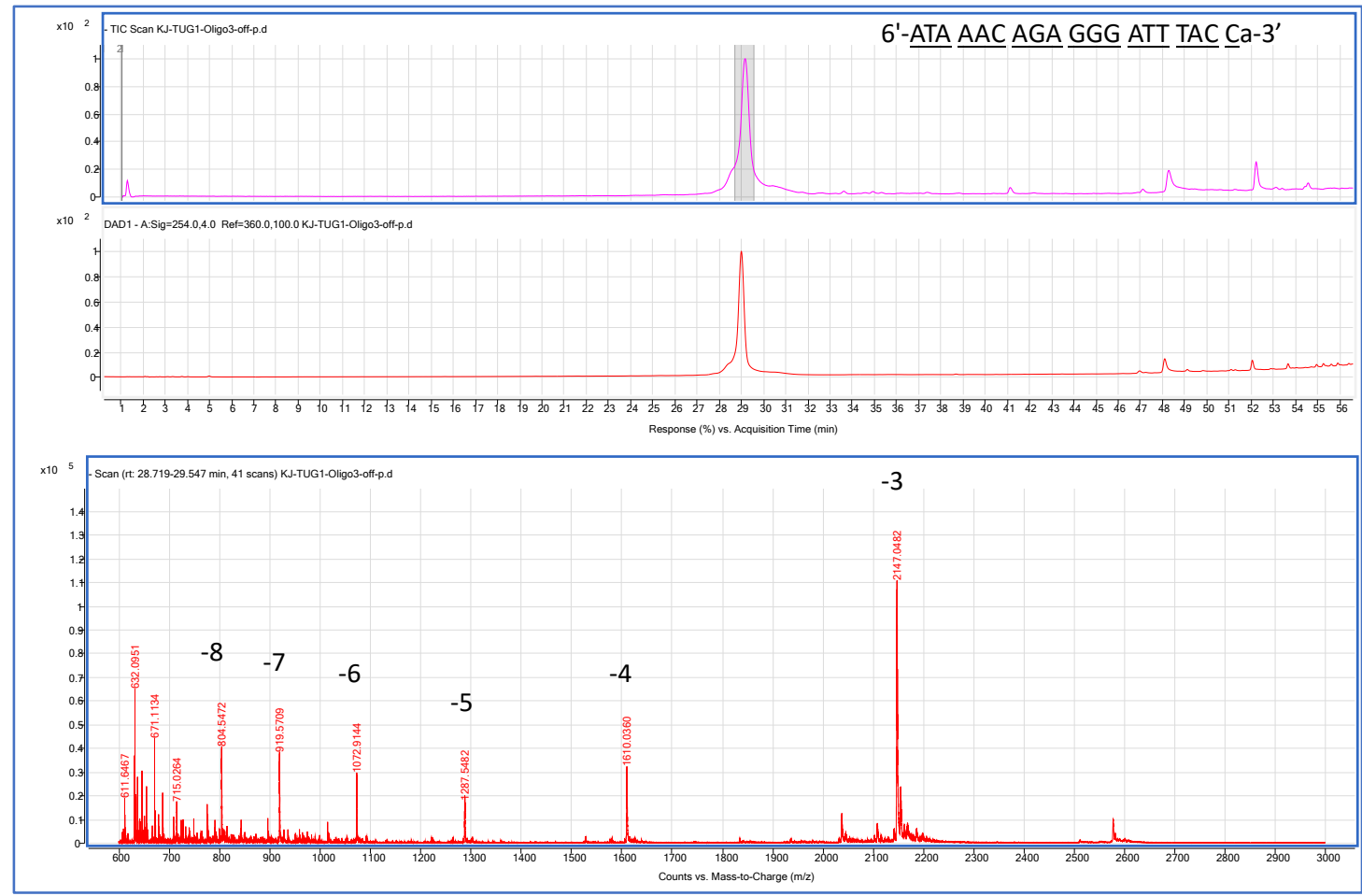

Figure S12(b). LCMS UV Profile and Mass Characterization of TMO14 after DMT-ON/OFF HPLC Purification. 


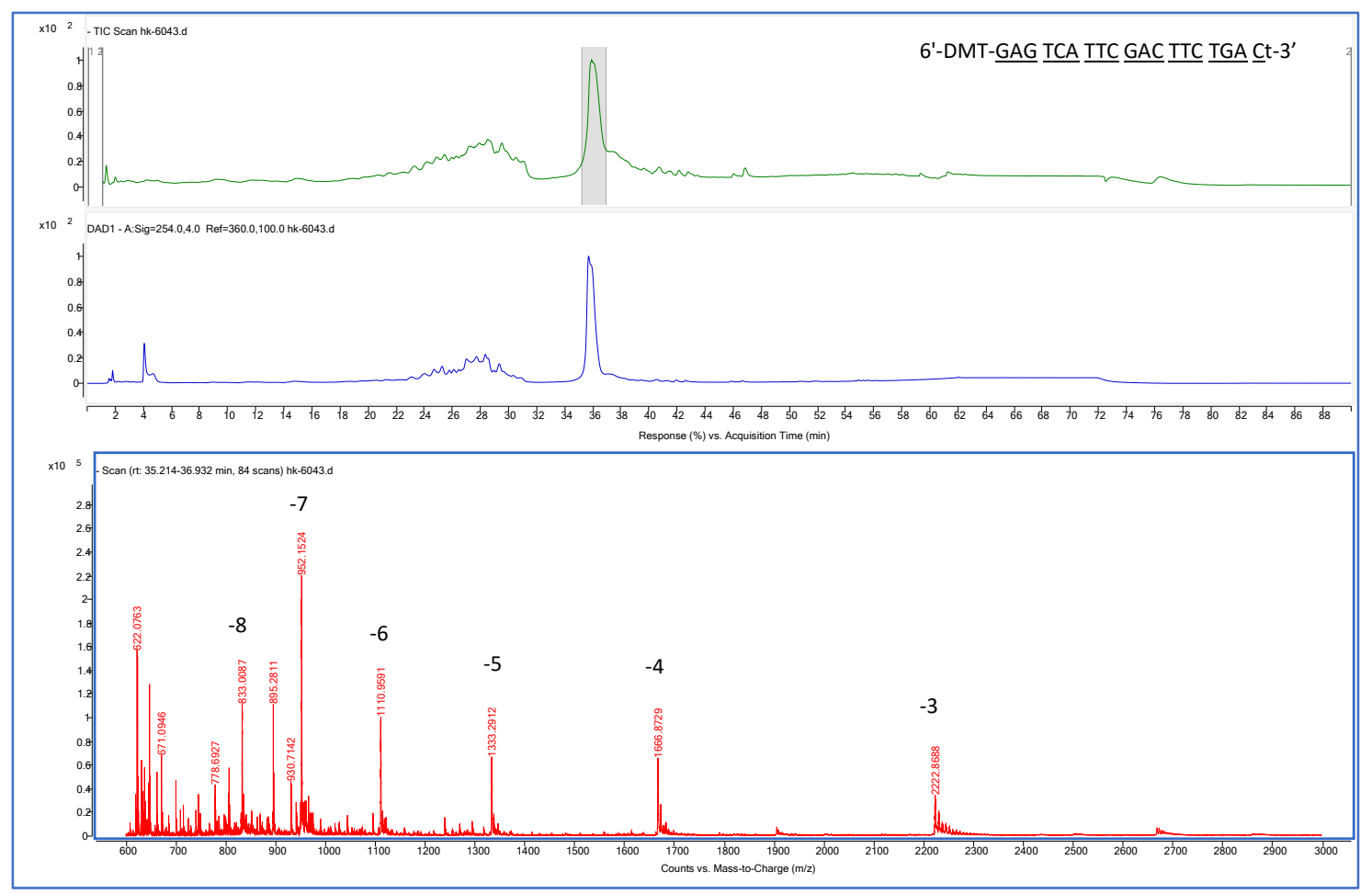

Figure S13. LCMS UV Profile and Mass Characterization of the crude reaction mixture of 6'-DMT TMO15.

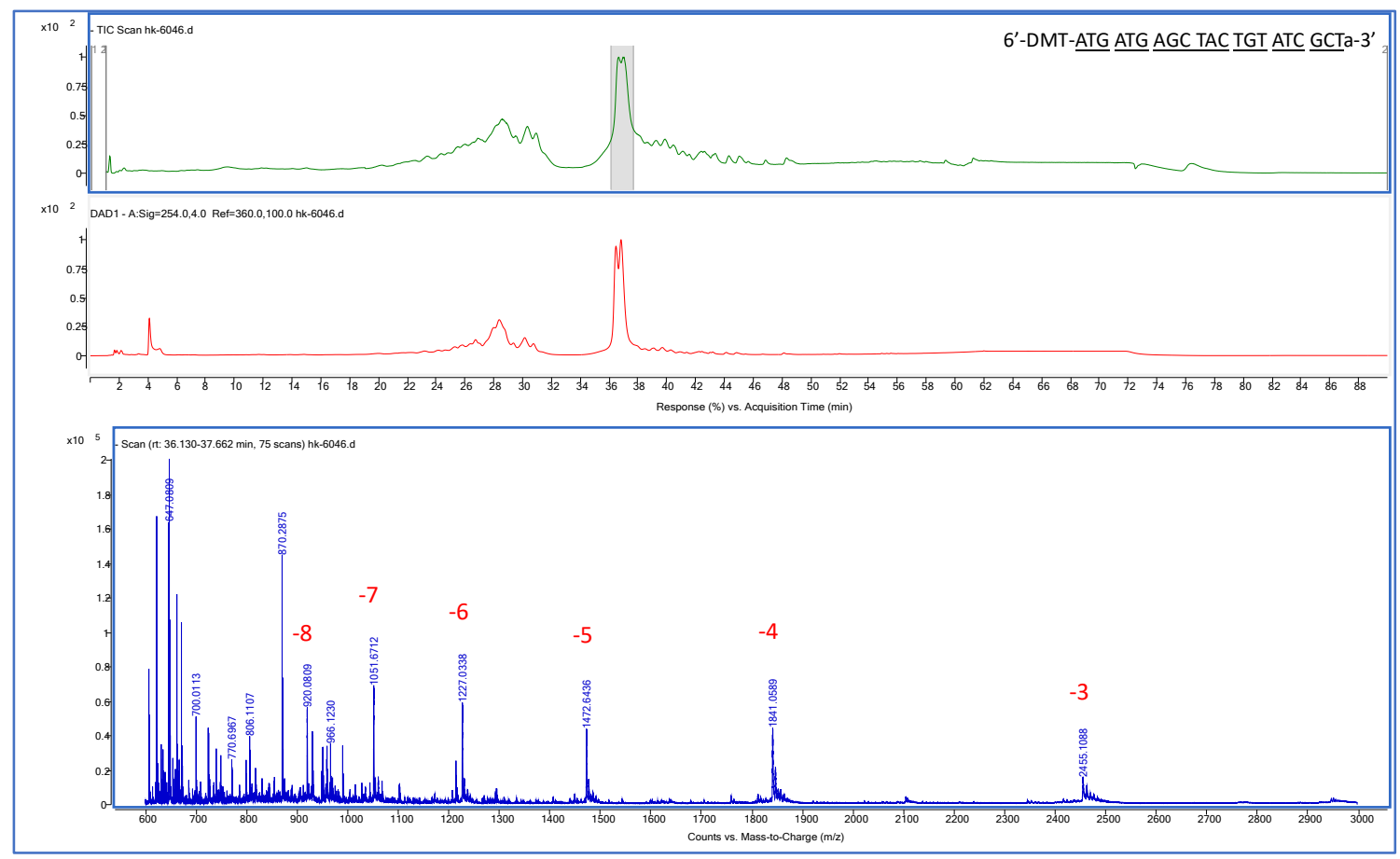

Figure S14. LCMS UV Profile and Mass Characterization of the crude reaction mixture of 6'-DMT TMO16. 


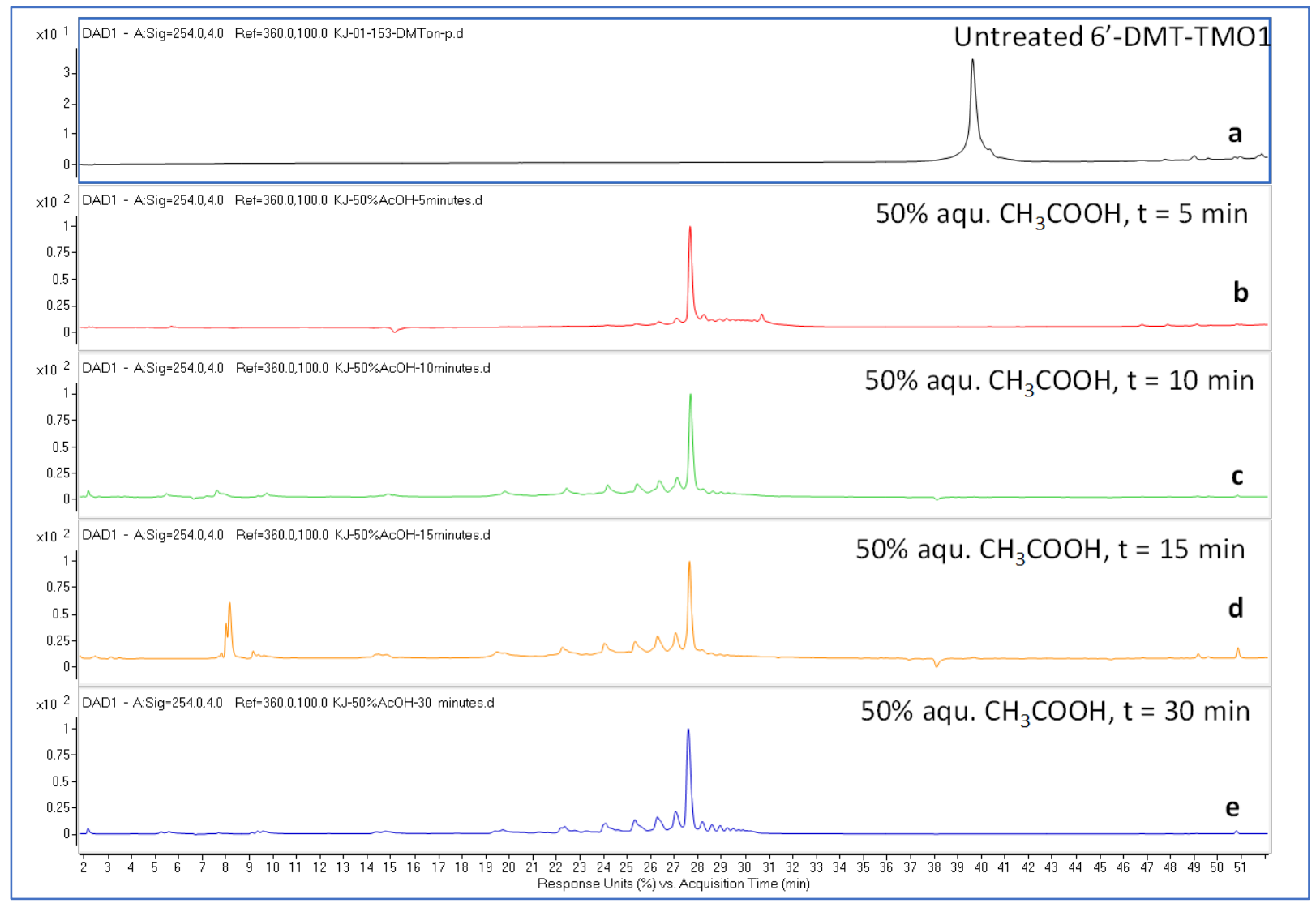

Figure S15. Stability of TMO1 (6'-DMT-ITT TTT TTT IIt-3'), when treated with $50 \%$ aqueous acetic acid (a) untreated TMO1; (b)-(e) TMO1 treated with 50\% aqueous acetic acid for 5, 10, 15 and 30 min respectively. LCMS analysis of TMO1 is provided in SI Figure S1. 
Table S1: Percentage yields of Oligonucleotides 1-16

\begin{tabular}{|c|c|c|}
\hline Oligo\# & Sequence Design* & $\begin{array}{l}\text { Percentage Yields } \\
\text { (UV integration or OD) * }\end{array}$ \\
\hline 1 & 6'-DMT-TTT TTT $\underline{\text { TTT }} \underline{\text { TTt-3' }}$ & $85 \%$ \\
\hline 2 & $6^{\prime}$-DMT-AGT $\underline{\text { TGC }} \underline{\text { CCT }} \underline{\text { GTG }} \mathrm{dT}^{F^{F I}}-3^{\prime}$ & $33 \%$ \\
\hline 3 & $6^{\prime}-\underline{\mathrm{T}} \underline{\mathrm{GTA}} \underline{\mathrm{AAC}} \underline{\mathrm{CAT}} \underline{\mathrm{GAT}} \underline{\mathrm{GTG}} \underline{\mathrm{CTG}} \underline{\mathrm{CT} a-3^{\prime}}$ & $30 \%$ \\
\hline 4 & $6^{\prime}-\underline{T}$ GTA aac cat gat gtg ct $\underline{\underline{C}} \underline{\mathrm{CT} a-3^{\prime}}$ & $45 \%$ \\
\hline 5 & 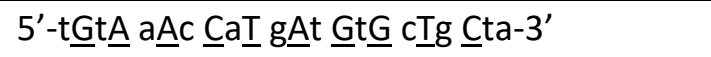 & $40 \%$ \\
\hline 6 & 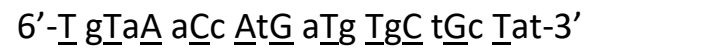 & $43 \%$ \\
\hline 7 & $6^{\prime}-\mathrm{FI}_{\mathrm{s}}-\underline{\mathrm{TT}} \underline{\mathrm{TTT}} \underline{\mathrm{TTT}} \underline{\mathrm{TTT}} \underline{\mathrm{TTt}} \mathrm{t} \mathrm{3}^{\prime}$ & 29 OD \\
\hline 8 & $6^{\prime}-\mathrm{Fl}_{\mathrm{s}}-\underline{\mathrm{TI}} \underline{\mathrm{TTT}} \underline{\mathrm{TTT}} \underline{\mathrm{TTT}} \underline{\mathrm{TTT}}-3^{\prime}$ & $26 \mathrm{OD}$ \\
\hline 9 & 6'-ATC $\underline{\text { CAA }} \underline{\text { CTT }} \underline{\text { ACC }} \underline{\text { GTG }} \underline{\text { ATc-3' }}$ & $36 \%$ \\
\hline 10 & $5^{\prime}-\mathrm{Fl}_{\mathrm{s}}-\mathrm{t}_{\mathrm{p}} \mathrm{t}_{\mathrm{p}} \mathrm{t}_{\mathrm{p}} \mathrm{t}_{\mathrm{p}} \mathrm{t}_{\mathrm{p}} \mathrm{t}_{\mathrm{p}} \mathrm{t}_{\mathrm{p}} \mathrm{t}_{\mathrm{p}} \mathrm{t}_{\mathrm{p}} \mathrm{t}_{\mathrm{p}} \mathrm{t}_{\mathrm{p}} \mathrm{t}_{\mathrm{p}} \mathrm{t}_{\mathrm{p}} \mathrm{tT}-\mathrm{3}^{\prime}$ & 89 OD \\
\hline 11 & 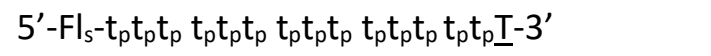 & $93 \mathrm{OD}$ \\
\hline 12 & $5^{\prime}-\mathrm{FI}_{\mathrm{s}}-\mathrm{ttt} \mathrm{ttt} \mathrm{ttt} \mathrm{ttt} \mathrm{tt}-3^{\prime}$ & 109 OD \\
\hline 13 & $5^{\prime}-\left.F\right|_{s}-t_{p} t_{p} t_{p} t_{p} t_{p} t_{p} t_{p} t_{p} t_{p} t_{p} t_{p} t_{p} t_{p} t-3^{\prime}$ & 112 OD \\
\hline 14 & 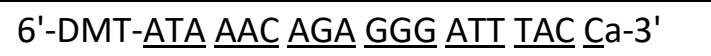 & $40 \%$ \\
\hline 15 & 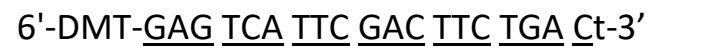 & $41 \%$ \\
\hline 16 & 6'-DMT-ATG ATG AGC TAC TGT ATC GCTa-3' & $43 \%$ \\
\hline
\end{tabular}

*For DMT-On oligonucleotides, percentage yields were calculated based on the integration of DMT-On product versus failures. For fluorescein labeled ONs, the final isolated yields after HPLC purification are also reported in micrograms and nanomoles in Table 1, main text. 


\section{Nuclease Susceptibility of TMOs Towards Snake Venom Phosphodiesterase I (SVPDE)}

Snake Venom Phosphodiesterase I (Crotalus Adamanteus) was purchased from Sigma (St. Louis, MO). Nuclease-free water was obtained from Thermo Fisher Scientific.

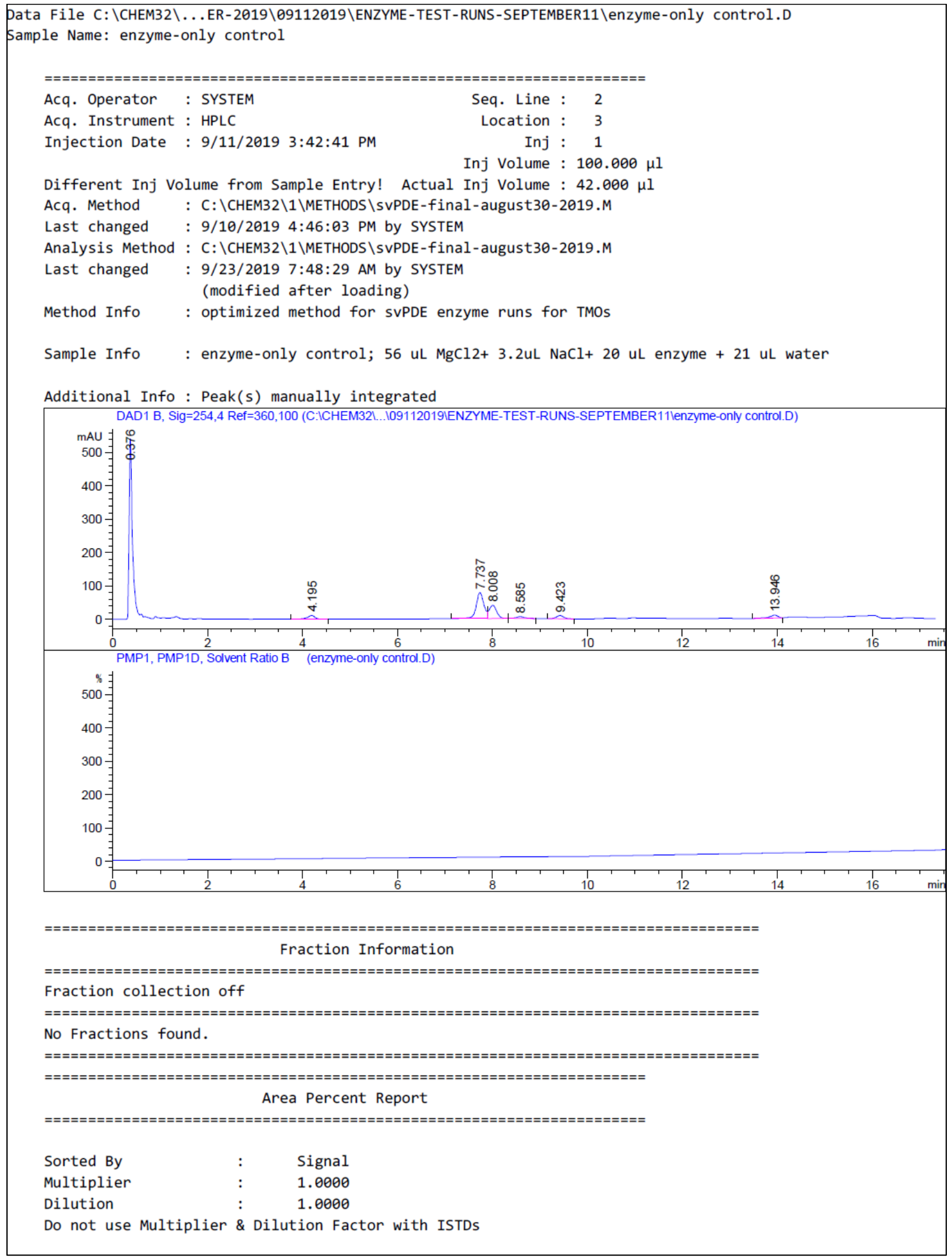

Figure S16. Analytical RP-HPLC Profile of SVPDE Reaction Mixture Prior to the Addition of TMO8. 
Data File C: \CHEM32\...A \HEERA 2019\SEPTEMBER-2019\09092019\6067-SEPTEMBER-9\ctrl-6067-2.D

Sample Name: ctrl-6067-2
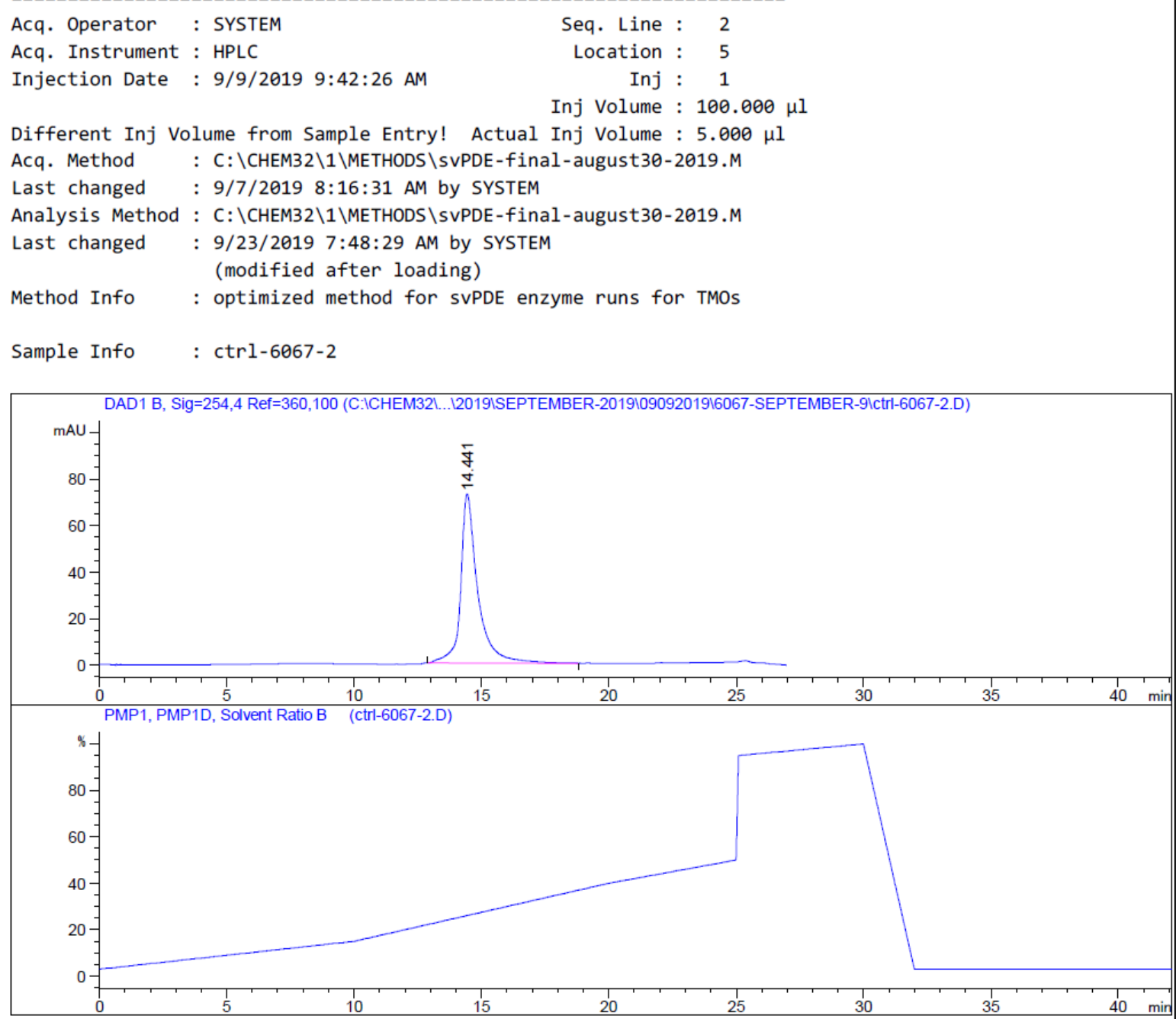

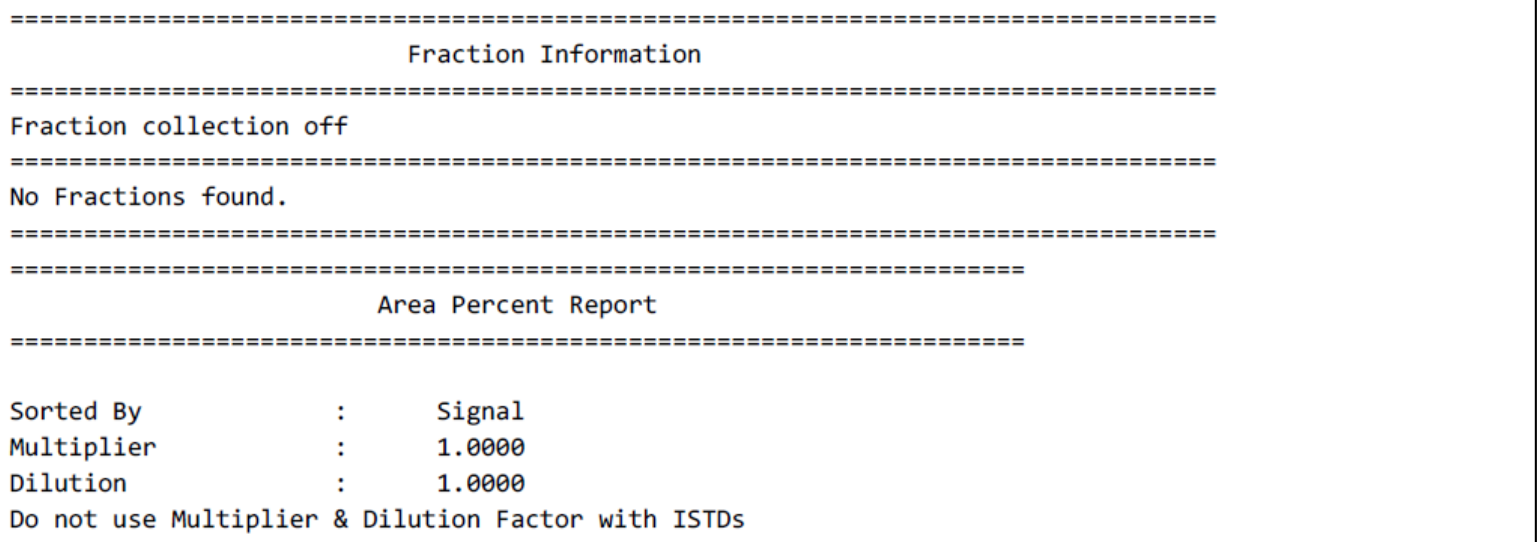

Figure S17. Analytical RP-HPLC Profile of Pure TMO8 (Table 1) Prior to SVPDE assay. 
pata File C: \CHEM32\...A\2019\SEPTEMBER-2019\09102019\6067-SEPTEMBER-10\6067-5-min-SVPDE.D

Sample Name: 6067-5-min
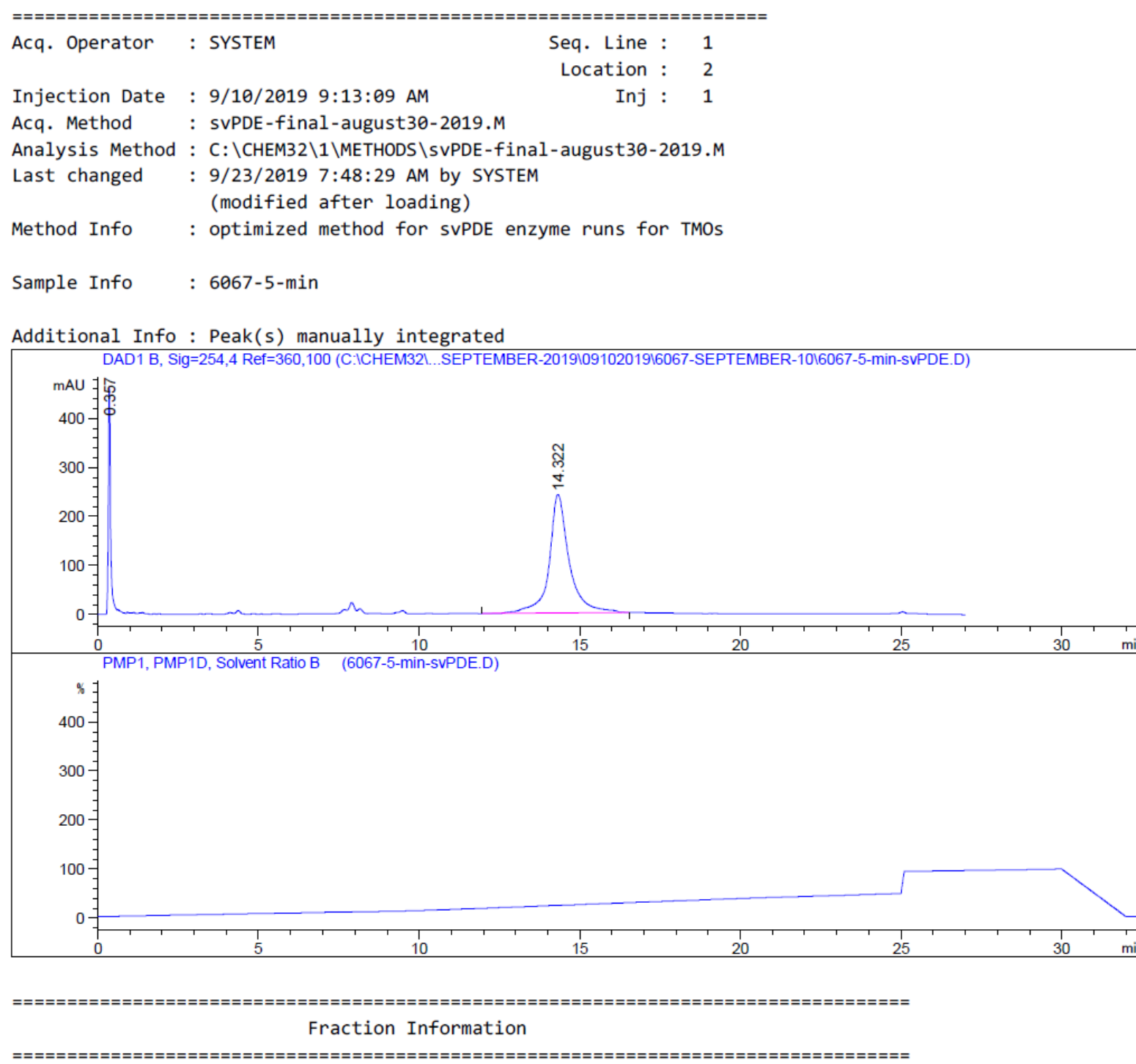

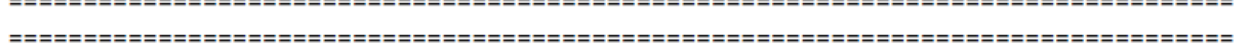

No Fractions found.

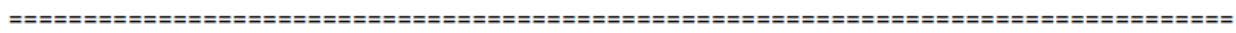

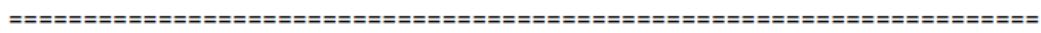

Area Percent Report

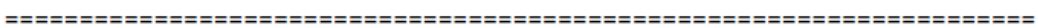

Sorted By : Signal

Multiplier : : 1.0000

Dilution : $\quad 1.0000$

Do not use Multiplier \& Dilution Factor with ISTDS

Figure S18. Analytical RP-HPLC Profile Obtained During the SVPDE Reaction of TMO8 at $\mathrm{t}=5$ minutes. HPLC fractions corresponding to Rt $=13-16$ minutes were used for LCMS reanalysis to check for degradation. 
pata File C: \CHEM32\...A\2019\SEPTEMBER-2019\09102019\6067-SEPTEMBER-10\6067-25min-SVPDE.D

Sample Name: 6067-25min

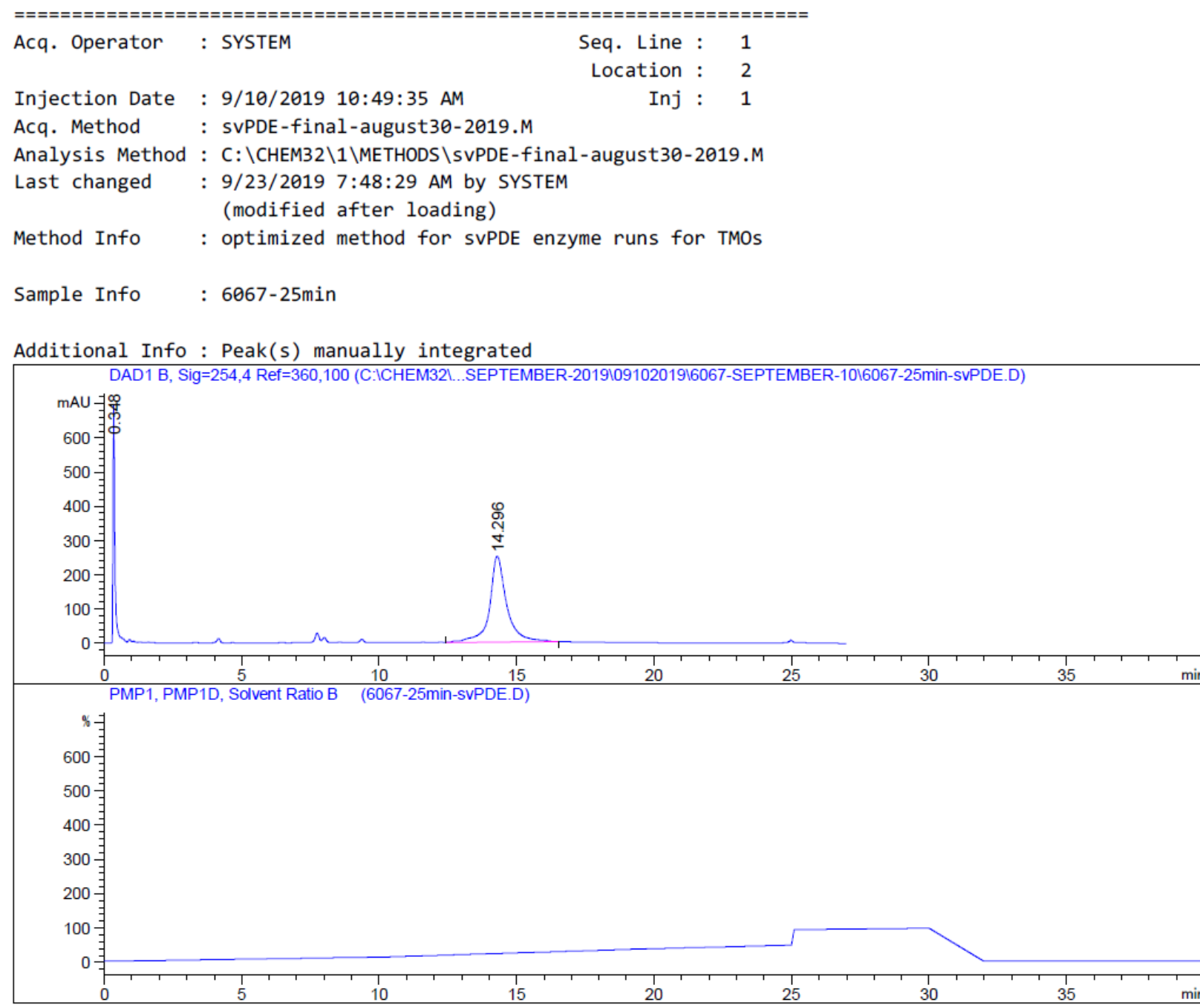

Fraction Information

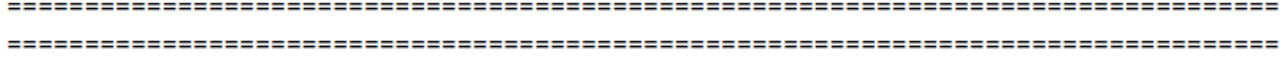

No Fractions found.

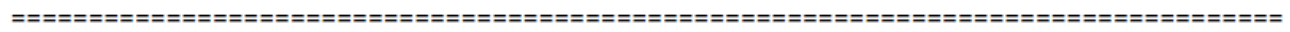

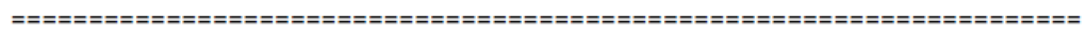

Area Percent Report

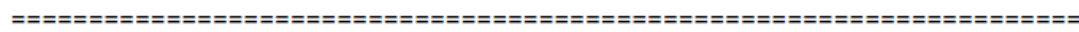

Sorted By $\quad$ : $\quad$ Signal

Multiplier $\quad: \quad 1.0000$

Dilution : 1.0000

Do not use Multiplier \& Dilution Factor with ISTDs

Figure S19. Analytical RP-HPLC Profile Obtained During the SVPDE Reaction of TMO8 at $\mathrm{t}=25 \mathrm{~min}$. HPLC fractions corresponding to $\mathrm{Rt}=13-16$ minutes were used for LCMS reanalysis to check for degradation. 
Data File C: \CHEM32\...A\2019\SEPTEMBER-2019\09102019\6067-SEPTEMBER-10\6067-60min-svPDE.D Sample Name: 6067-60min
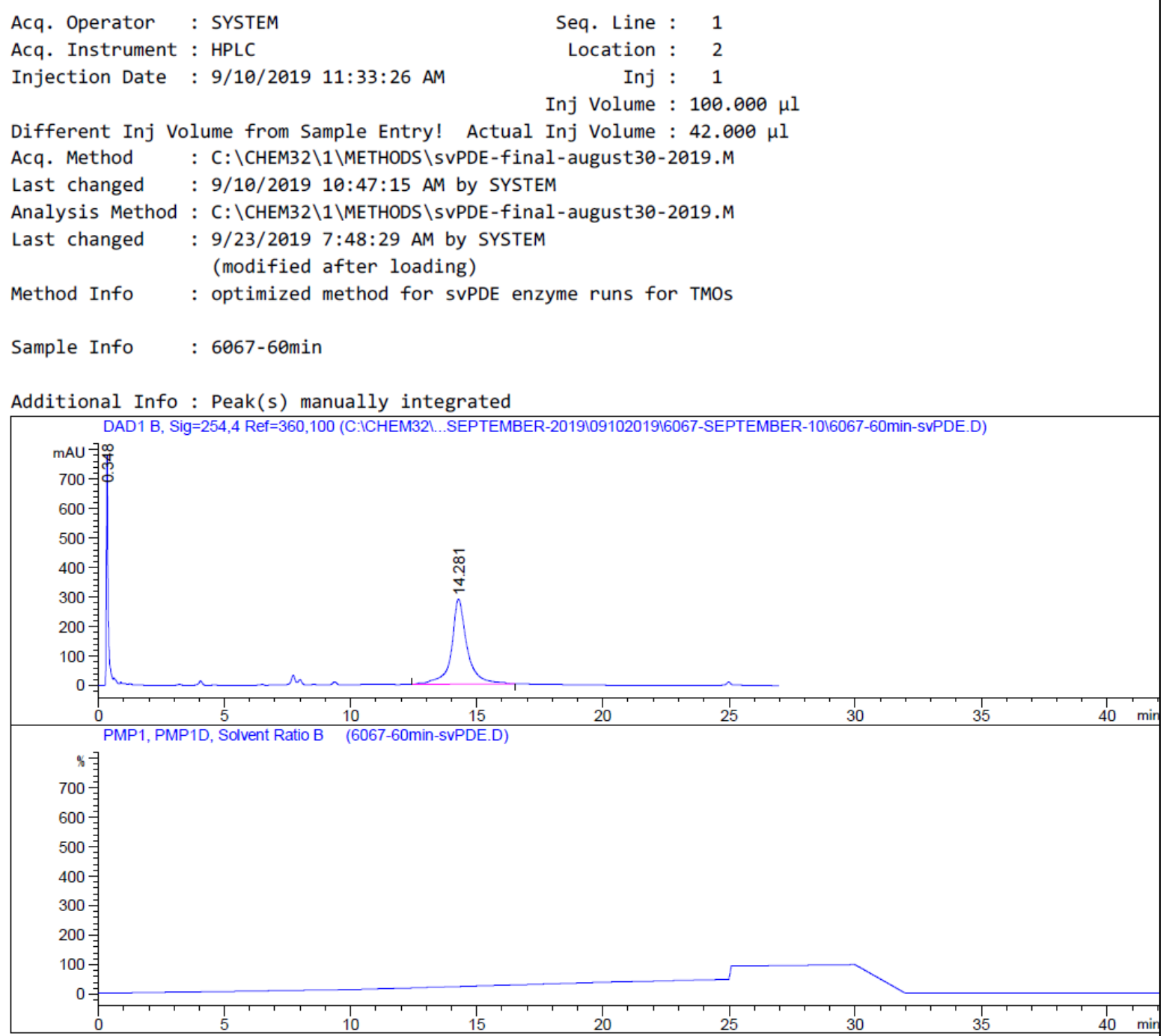

Figure S20. Analytical RP-HPLC Profile Obtained During the SVPDE Reaction of TMO8 at $t=60 \mathrm{~min}$. HPLC fractions corresponding to $\mathrm{Rt}=13-16 \mathrm{~min}$ were used for LCMS re-analysis to check for degradation. 
Data File C: \CHEM32\...EERA\2019\SEPTEMBER-2019\09102019\6067-SEPTEMBER-10\6067-4h-SVPDE.D Sample Name: $6067-4 \mathrm{~h}$

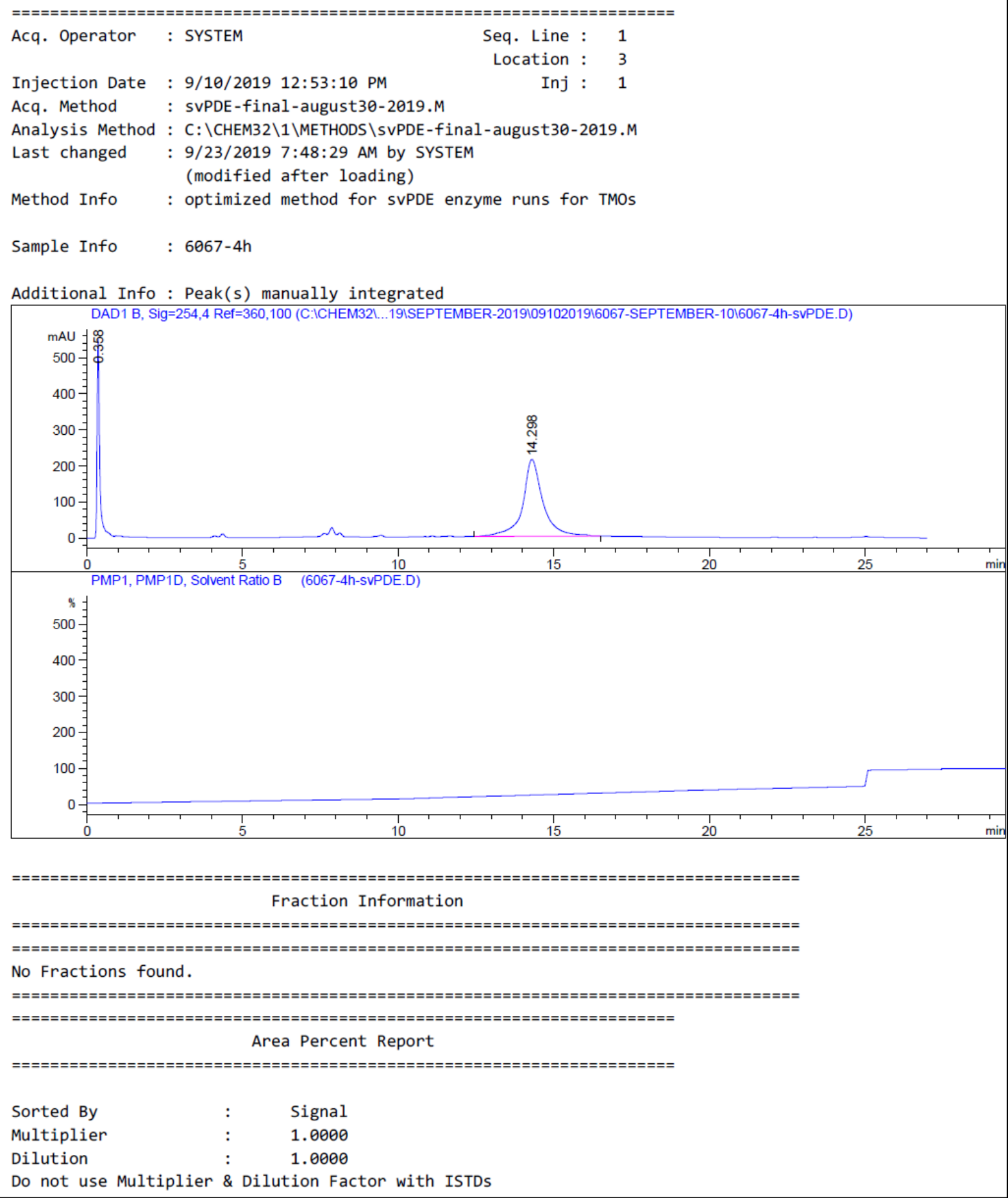

Figure S21. Analytical RP-HPLC Profile Obtained During the SVPDE Reaction of TMO8 at $\mathrm{t}=4 \mathrm{~h}$. HPLC fractions corresponding to $\mathrm{Rt}=13-16$ min were used for LCMS reanalysis to check for degradation. 
Data File C: \CHEM32\1\DATA\HEERA\2019\SEPTEMBER-2019\09102019\6067-SEPTEMBER-10\6067-8h.D Sample Name: 6067-8h
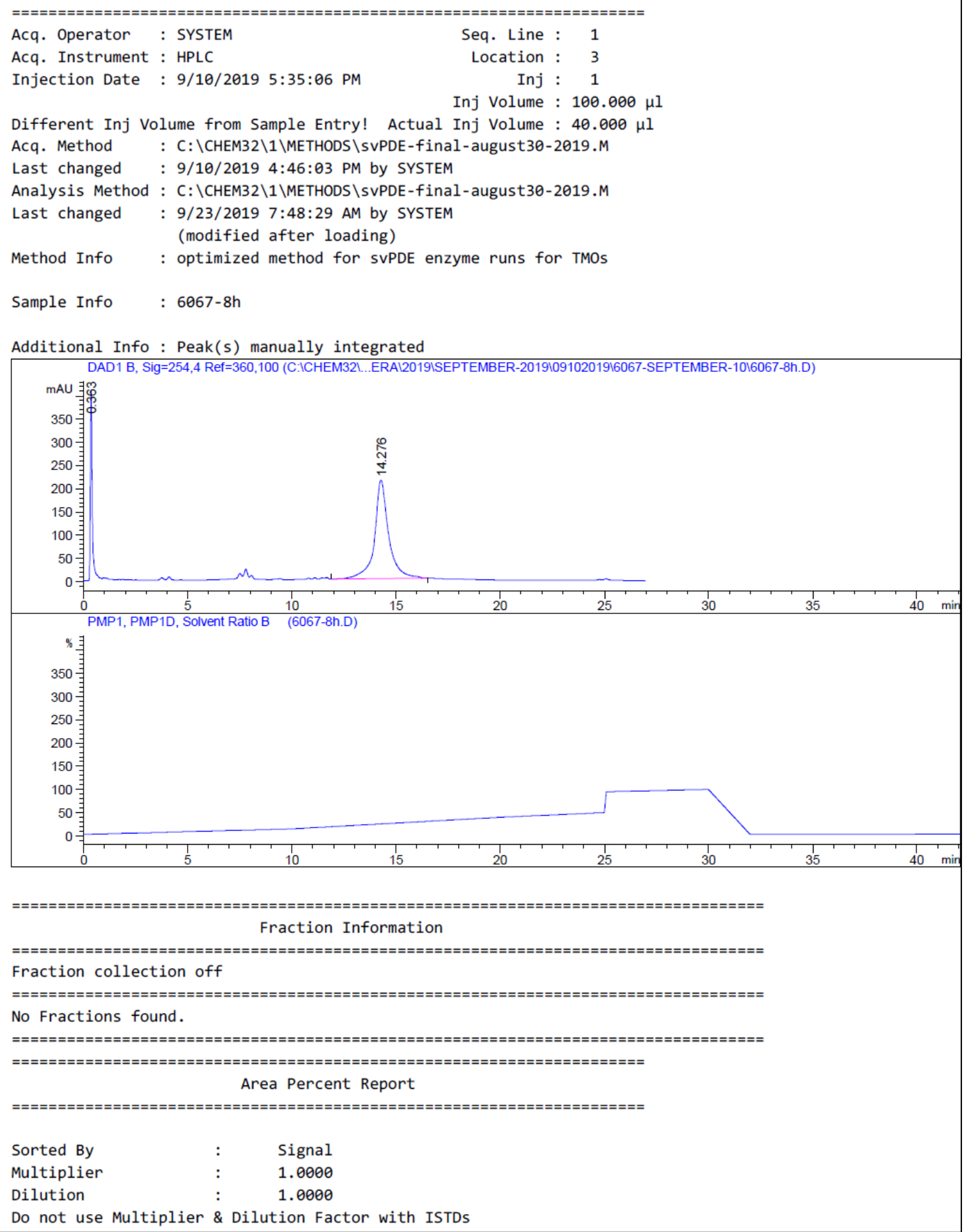

Figure S22. Analytical RP-HPLC Profile Obtained During the SVPDE Reaction of TMO8 at $t=8 \mathrm{~h}$. HPLC fractions corresponding to $\mathrm{Rt}=13-16$ min were used for LCMS reanalysis to check for degradation. 


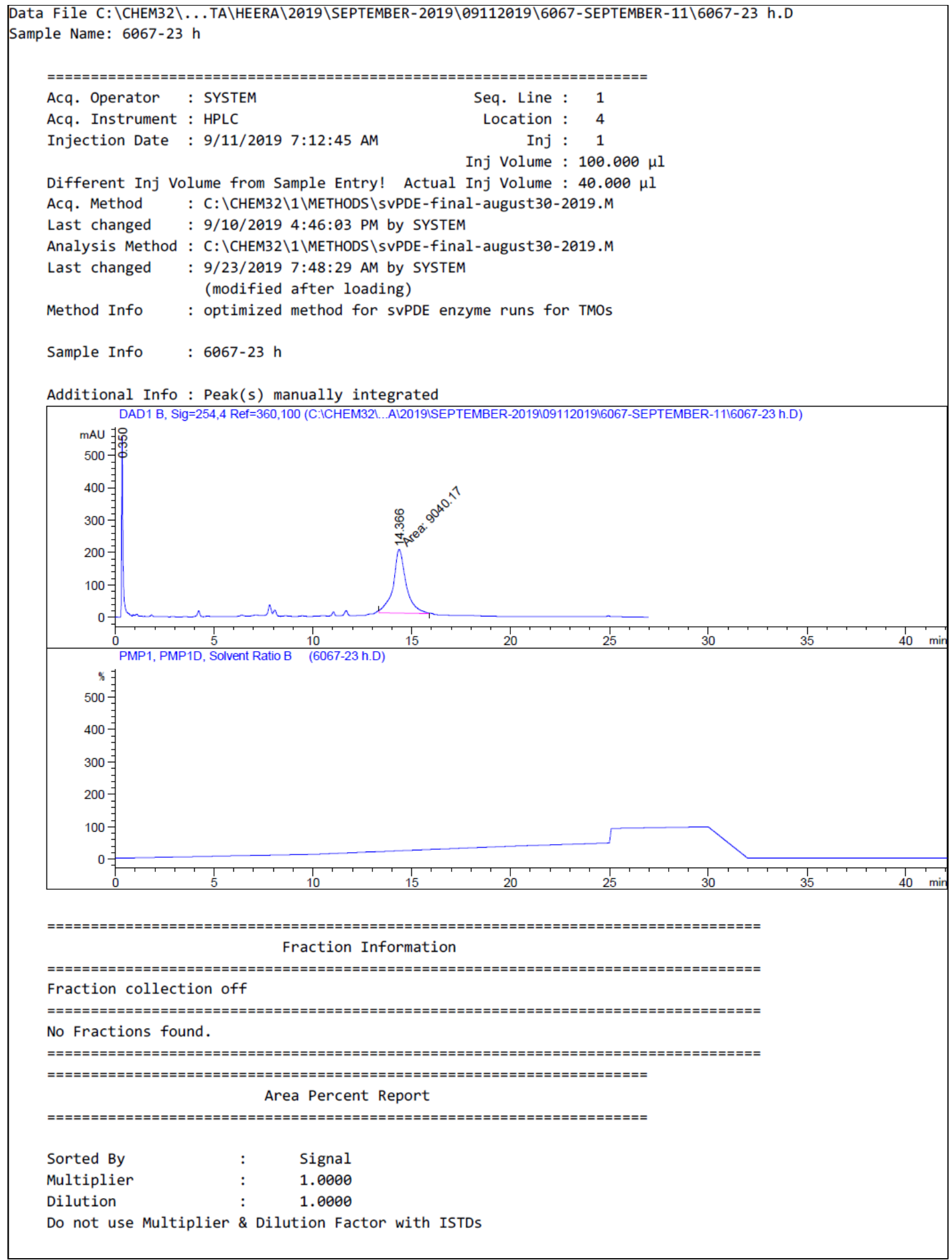

Figure S23. Analytical RP-HPLC Profile Obtained During the SVPDE Reaction of TMO8 at $t=23 \mathrm{~h}$. HPLC fractions corresponding to $\mathrm{Rt}=13-16 \mathrm{~min}$ were used for LCMS reanalysis to check for degradation. 


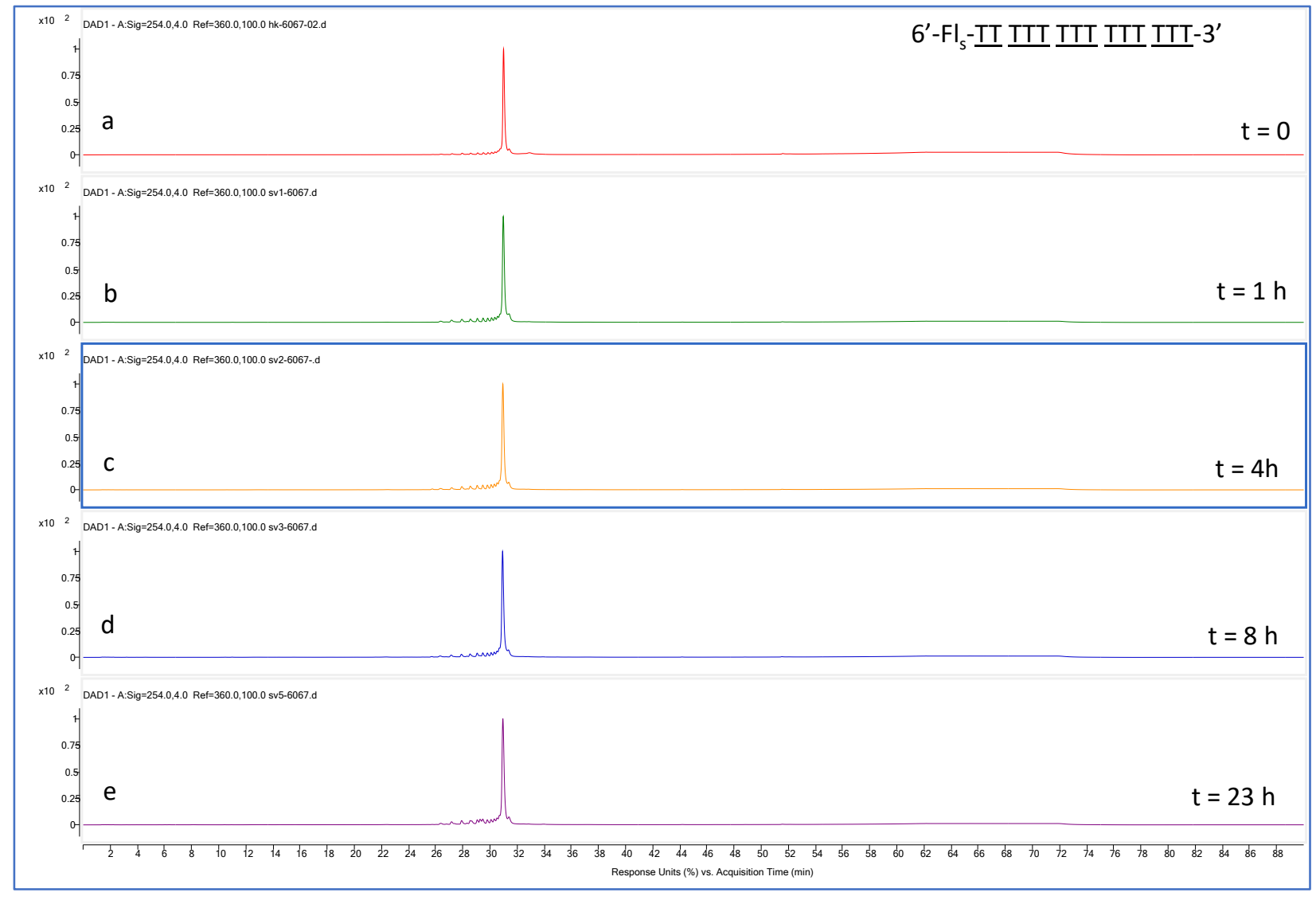

Figure S24. LCMS Analysis of TMO8 at Various Time-points During the SVPDE Assay. Analytical RP-HPLC Fractions corresponding to TMO8 were collected at various time points during SVPDE treatment (SI Figures S18-S23: Collected fractions with Rt $=13-16 \mathrm{~min})$. Figure 3, main text shows the $\mathrm{m} / \mathrm{z}$ analysis of untreated TMO8 $(\mathrm{t}=0)$ and TMO8 after SVPDE treatment $(\mathrm{t}=23 \mathrm{~h})$. 
Data File C: \CHEM32\...SEPTEMBER-2019\09112019\ENZYME-TEST-RUNS-SEPTEMBER11 \enzyme-water.D Sample Name: ENZYME
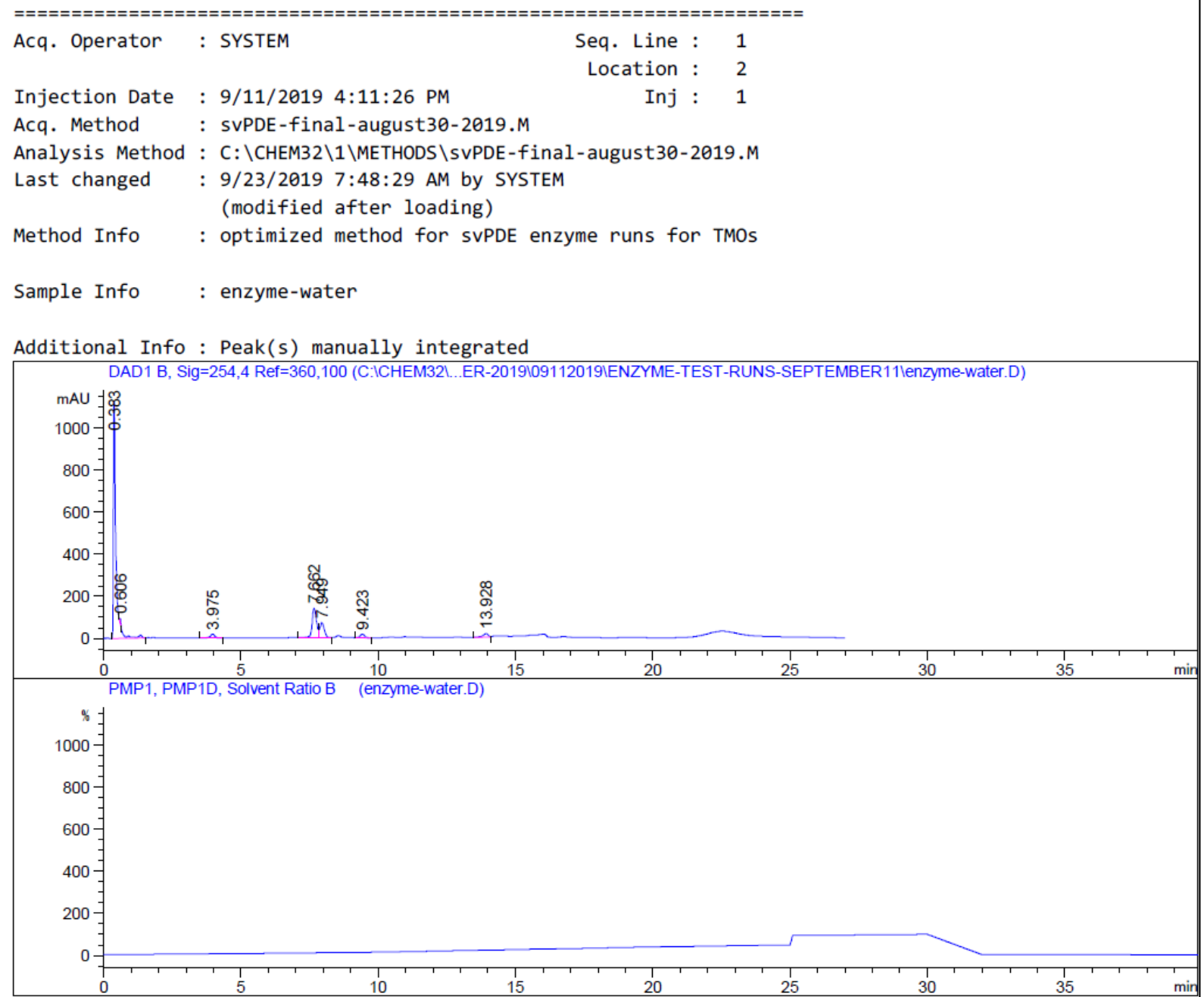

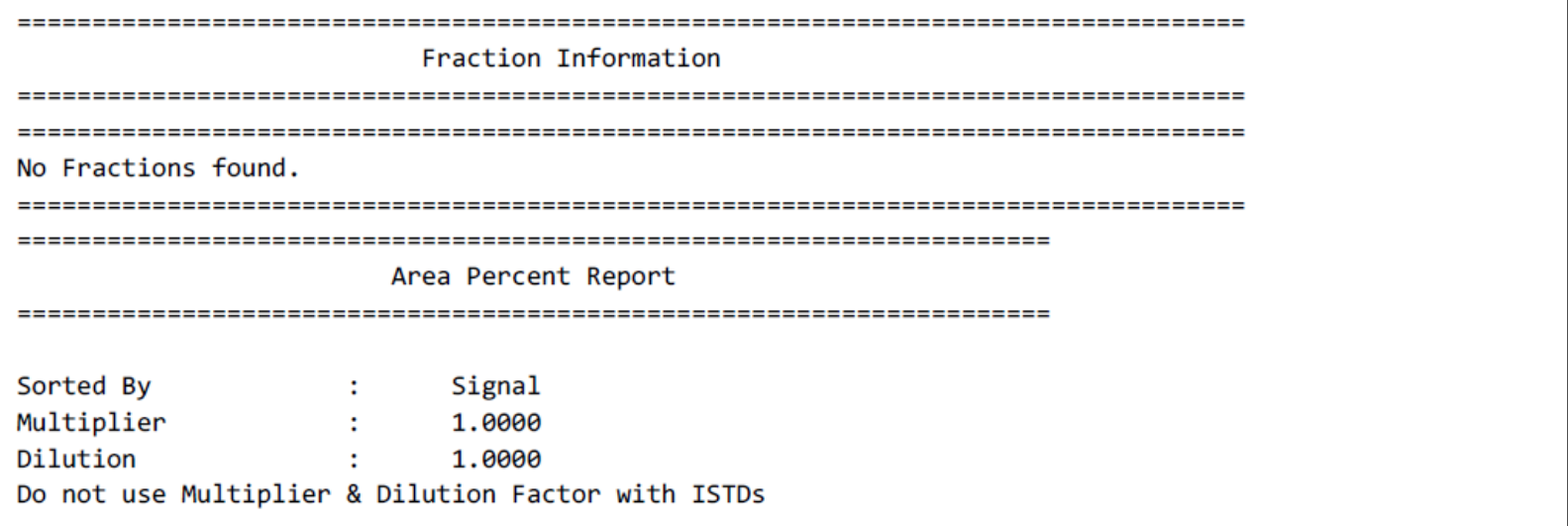

Figure S25. Analytical RP-HPLC Profile of SVPDE Sample Prior to the Addition of Control pS-DNA ON12. 


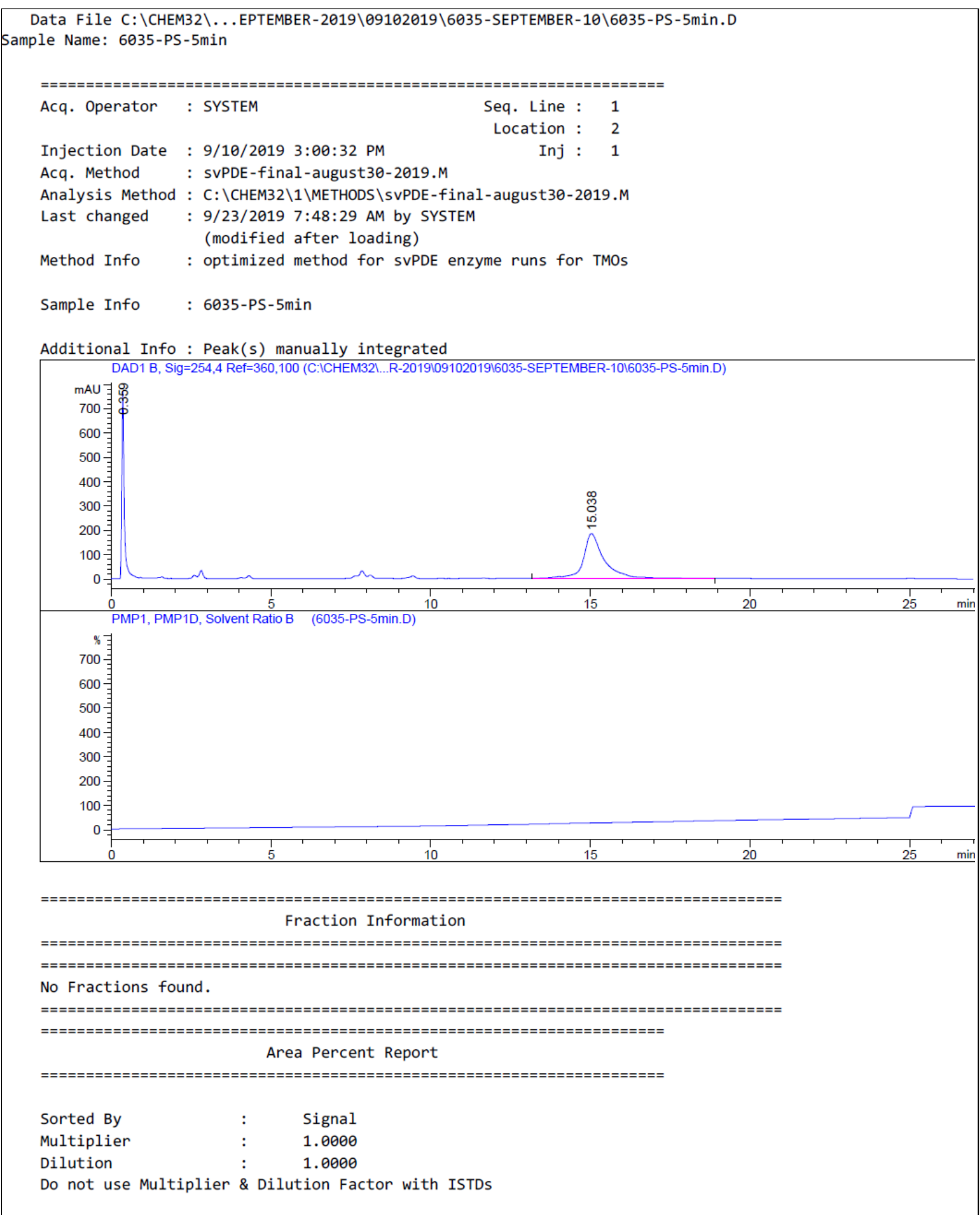

Figure S26. Analytical RP-HPLC Profile Obtained During the SVPDE Reaction of ON12 at $\mathrm{t}=5$ minutes. 


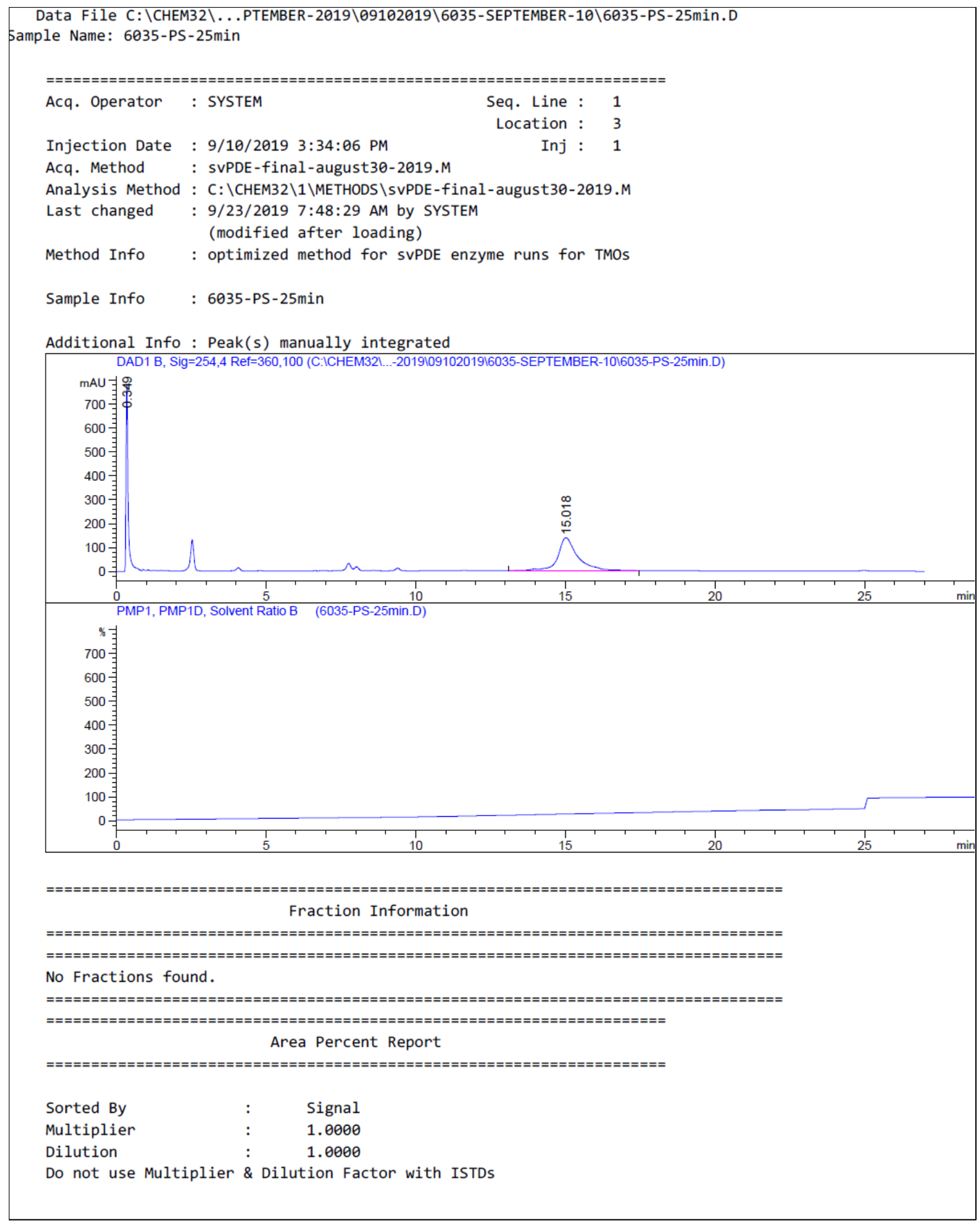

Figure S27. Analytical RP-HPLC Profile Obtained During the SVPDE Reaction of ON12 at $\mathrm{t}=25$ minutes. 
pata File C: \CHEM32\...TA \HEERA $2019 \backslash S E P T E M B E R-2019 \backslash 09112019 \backslash 6035-S E P T E M B E R-11 \backslash 6035-4.5 \mathrm{~h} . \mathrm{D}$

Sample Name: 6035-4.5h

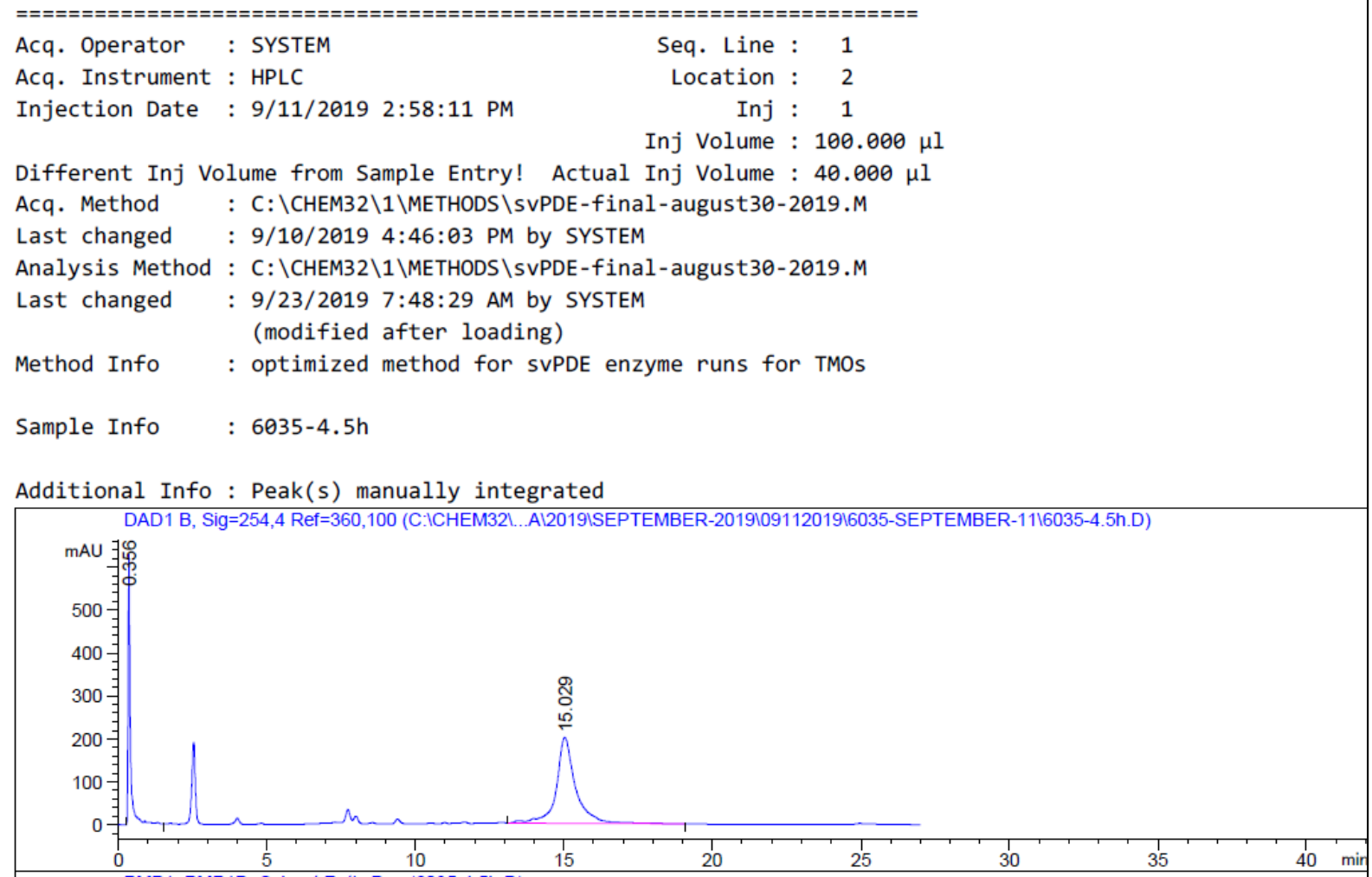

PMP1, PMP1D, Solvent Ratio B (6035-4.5h.D)
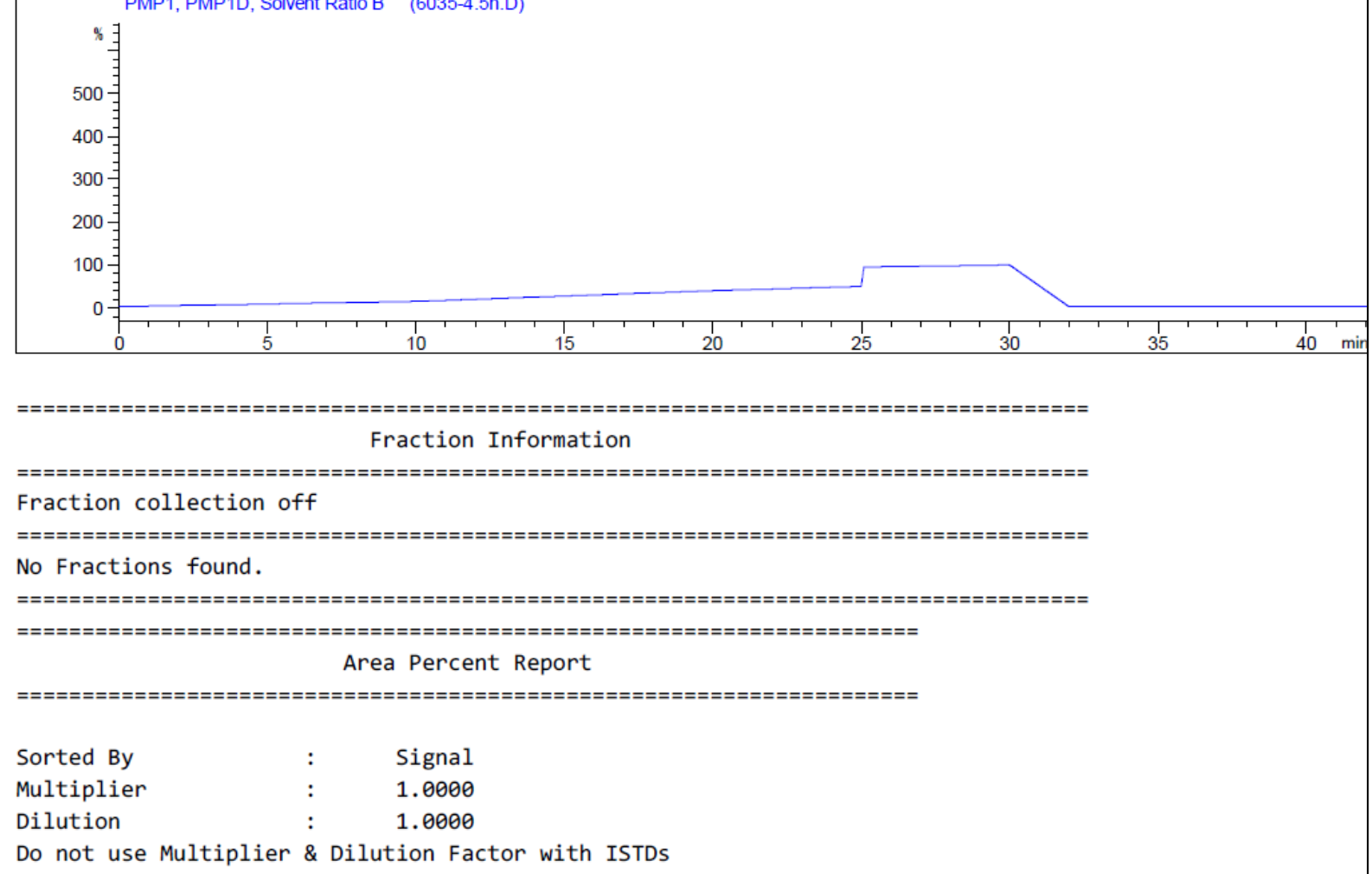

Figure S28. Analytical RP-HPLC Profile Obtained During the SVPDE reaction of ON12 at $t=4.5 \mathrm{~h}$. 
Data File C: \CHEM32\1\DATA\HEERA 2019\SEPTEMBER-2019\09112019\6035-SEPTEMBER-11\6035-7h.D

Sample Name: 6035-7

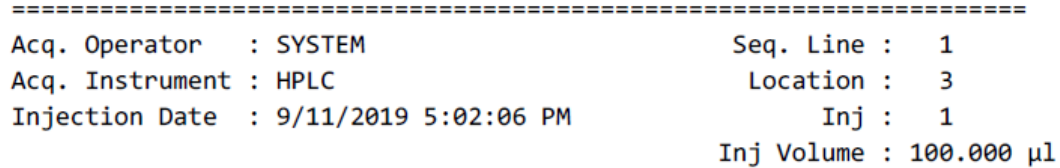

Different Inj Volume from Sample Entry! Actual Inj Volume : $40.000 \mu \mathrm{l}$

Acq. Method : C: \CHEM32\1\METHODS \SVPDE-final-august30-2019.M

Last changed : 9/10/2019 4:46:03 PM by SYSTEM

Analysis Method : C: \CHEM32\1\METHODS \SVPDE-final-august30-2019.M

Last changed : 9/23/2019 7:48:29 AM by SYSTEM

(modified after loading)

Method Info : optimized method for SVPDE enzyme runs for TMOs

Sample Info : 6035-7h

Additional Info : Peak(s) manually integrated

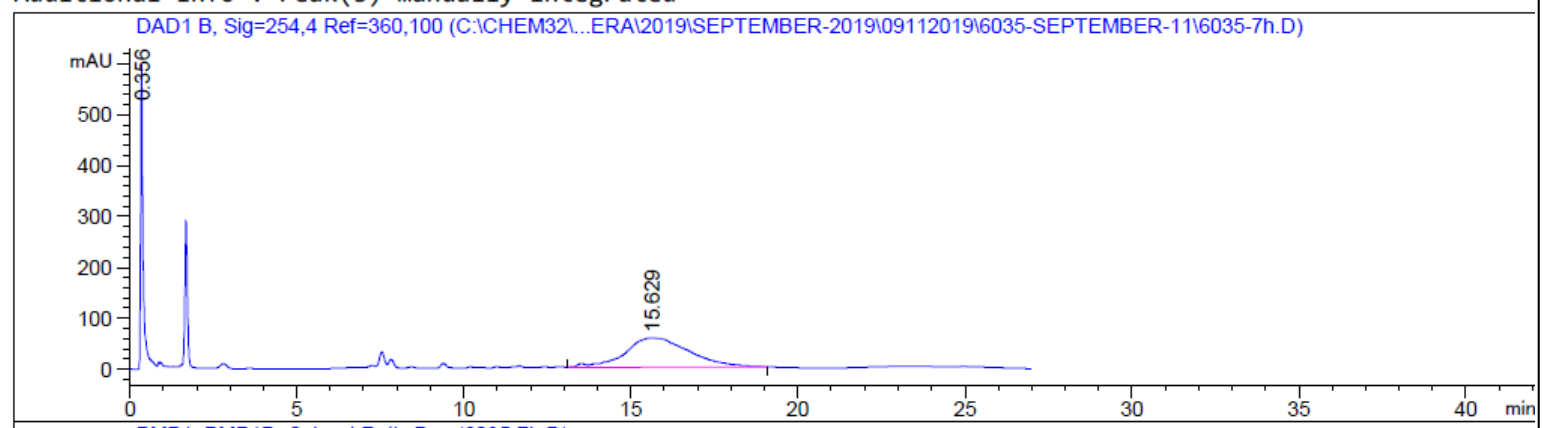

PMP1, PMP1D, Solvent Ratio B $\quad(6035-7 \mathrm{~h} . \mathrm{D})$

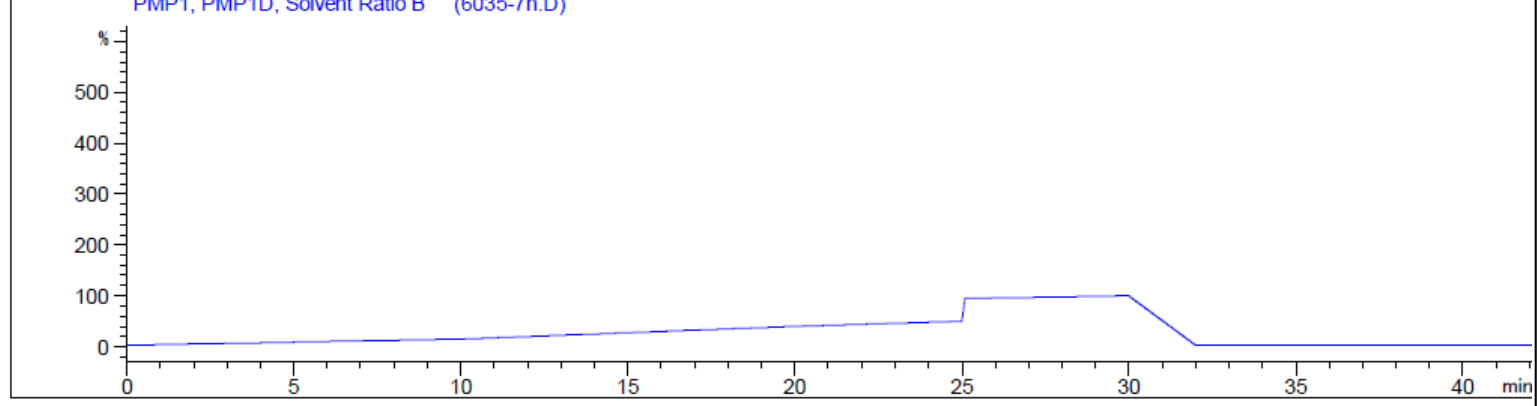

Fraction Information

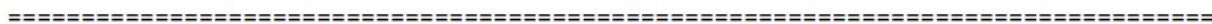

Fraction collection off

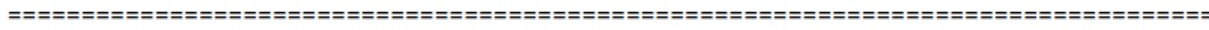

No Fractions found.

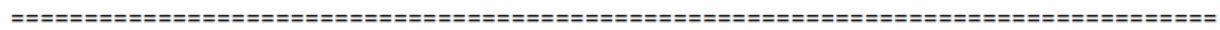

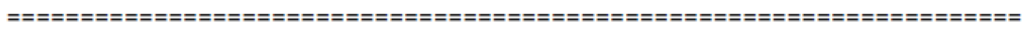

Area Percent Report

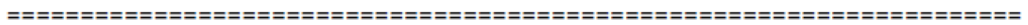

$\begin{array}{lll}\text { Sorted By } & : & \text { Signal } \\ \text { Multiplier } & : & 1.0000 \\ \text { Dilution } & : & 1.0000\end{array}$

Do not use Multiplier \& Dilution Factor with ISTDs

Figure S29. Analytical RP-HPLC Profile Obtained During the SVPDE Reaction of ON12 at $\mathrm{t}=7 \mathrm{~h}$. Pooled fractions at Rt $=14-18$ min was used for LCMS analysis to assess degradation (SI Figure S30). 


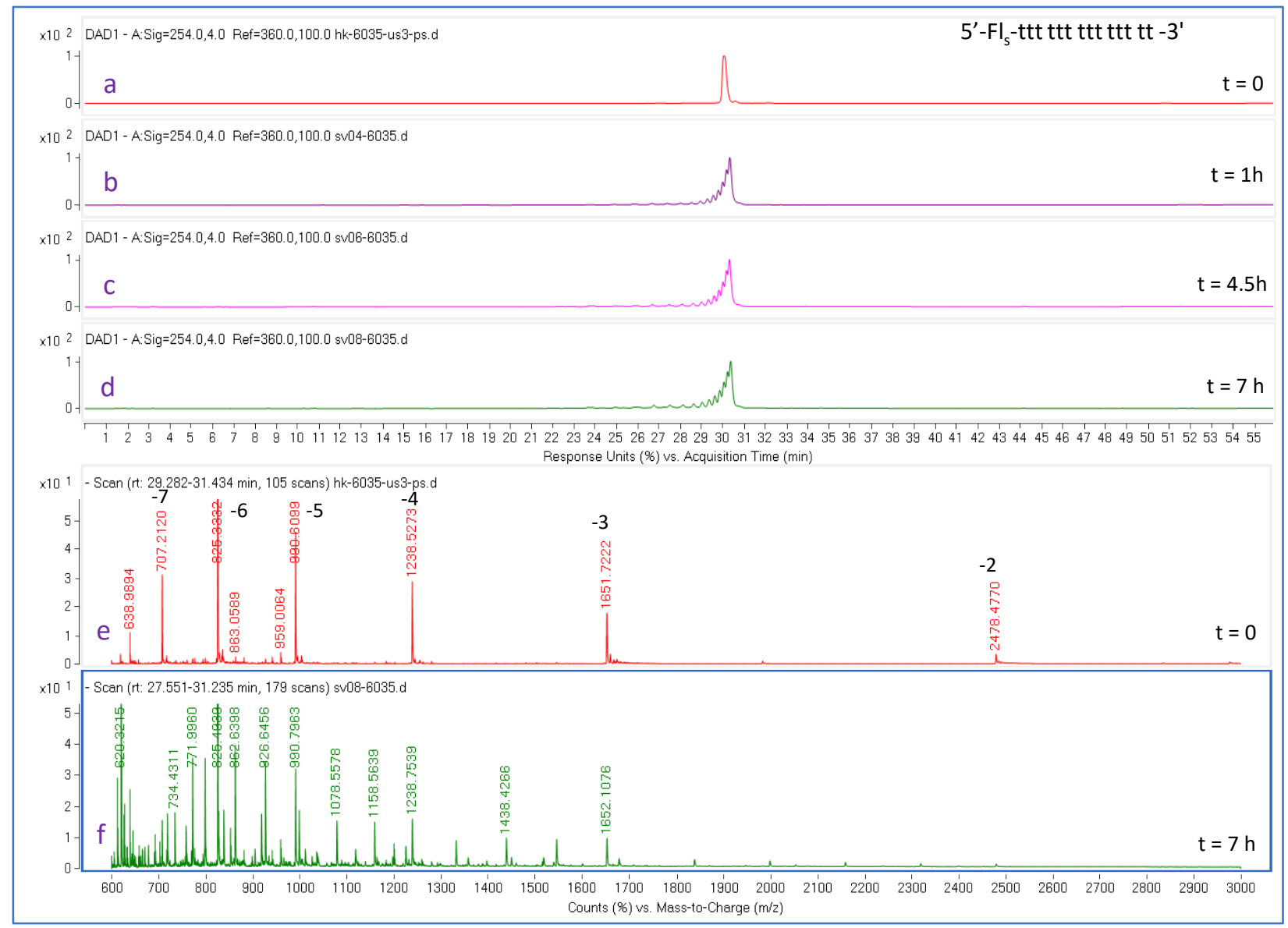

Figure S30. LCMS Analysis of DNA-pS Control ON12 At Various Time-points During SVPDE Assay. Figure S30 (a-d) shows the UV profiles corresponding to the ON12 peak that was collected during analytical HPLC of SVPDE-treated samples at various time points $(t=0,1 \mathrm{~h}, 4.5 \mathrm{~h}, 7 \mathrm{~h})$. Figure $\mathrm{S} 30$ e and $\mathrm{f}$ compare the $\mathrm{m} / \mathrm{z}$ spectra at $\mathrm{t}=0 \mathrm{~min}$ (Figure $\mathrm{S} 30 \mathrm{a}$ ), and $\mathrm{t}=7 \mathrm{~h}$ (Figure $\mathrm{S} 30 \mathrm{~d}$ ). SVPDE reaction conditions: $100 \mathrm{mM}$ Tris $\mathrm{pH}$ 9, $14 \mathrm{mM} \mathrm{MgCl} 2,72 \mathrm{mM} \mathrm{NaCl}, 13.3 \mu \mathrm{M} \mathrm{ON}, 1 \times 10^{-1} \mathrm{U} / \mathrm{mL}$ SVPDE. The analytical HPLC runs during which the ON12 fractions were collected are shown in SI Figures S26-S29; Rt of pooled fractions $=14-18 \mathrm{~min}$ of analytical HPLC runs. 


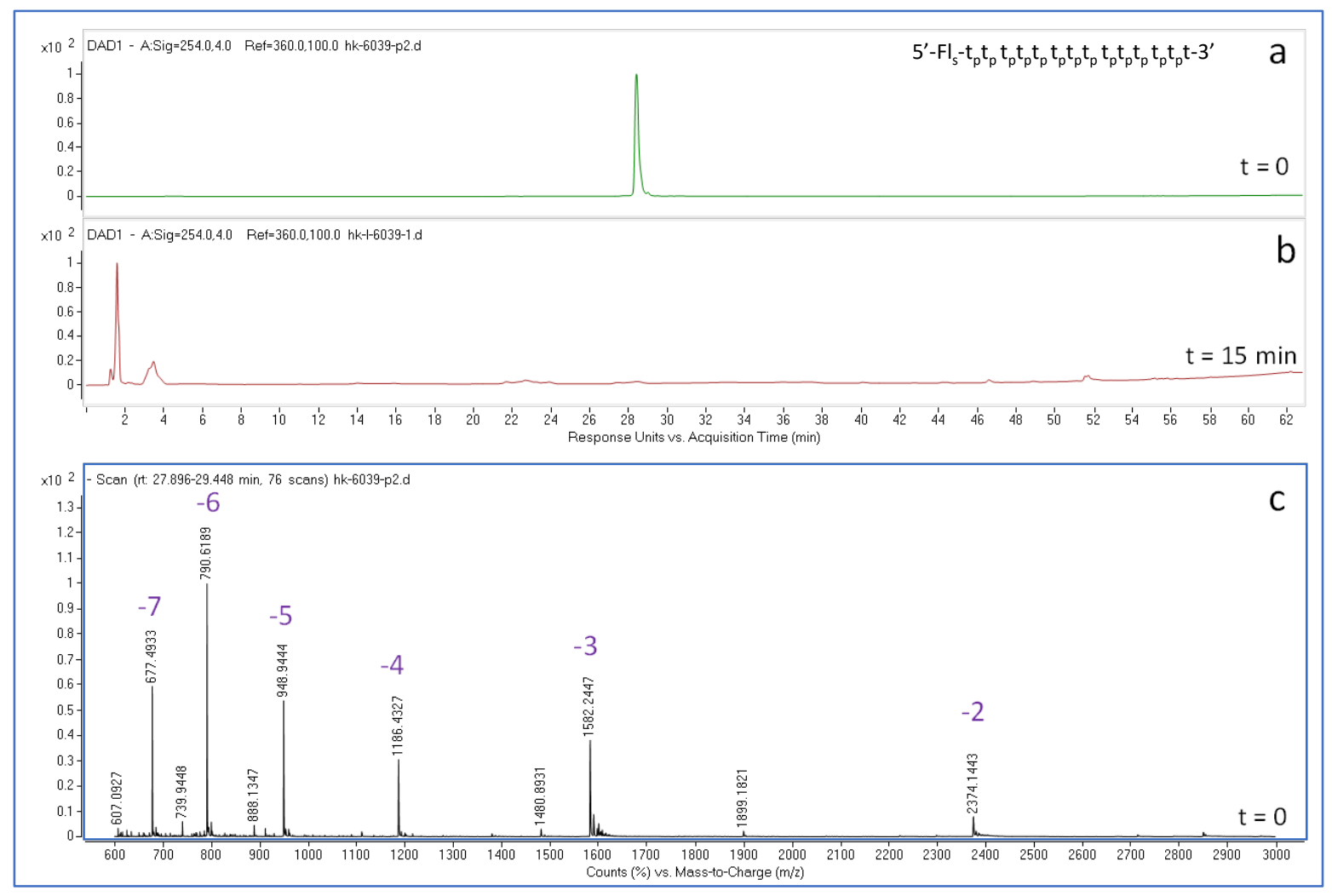

Figure S31. LCMS Analysis of unmodified DNA Control ON13 (Table 1) At Various Time-points During SVPDE Assay. Figure S17a shows the UV profile of ON13 prior to SVPDE treatment $(t=0)$. Figure S17b shows the UV profile of ON13 after SVPDE treatment for 15 minutes. Based upon the Rt comparison of UV profiles at $\mathrm{t}=0$ and $\mathrm{t}=15$, complete degradation of ON13 occurred within 15 minutes. Figure S31c shows the $\mathrm{m} / \mathrm{z}$ analysis of pure, undegraded ON13 (Rt $=27.8-29.4 \mathrm{~min}$ ). SVPDE Reaction Conditions: 100 $\mathrm{mM}$ Tris $\mathrm{pH}$ 9, $14 \mathrm{mM} \mathrm{MgCl} 2,72 \mathrm{mM} \mathrm{NaCl}, 13.3 \mu \mathrm{M}$ ON13, $1 \times 10^{-1} \mathrm{U} / \mathrm{mL}$ SVPDE. 

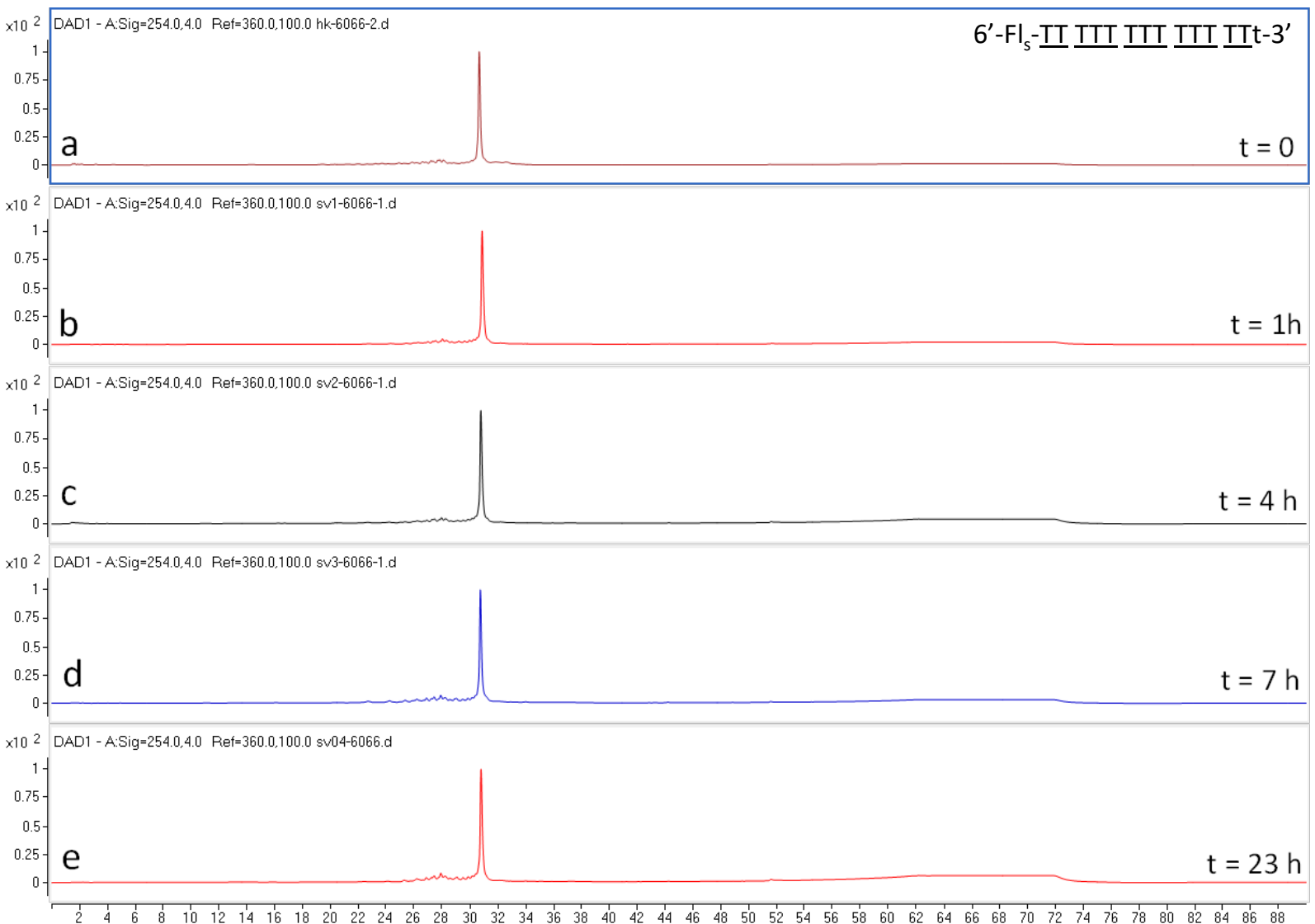

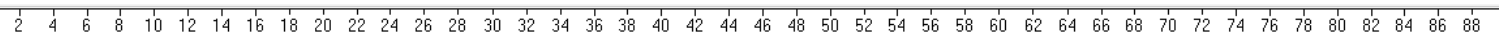
Response Units (\%) vs. Acquisition Time (min)

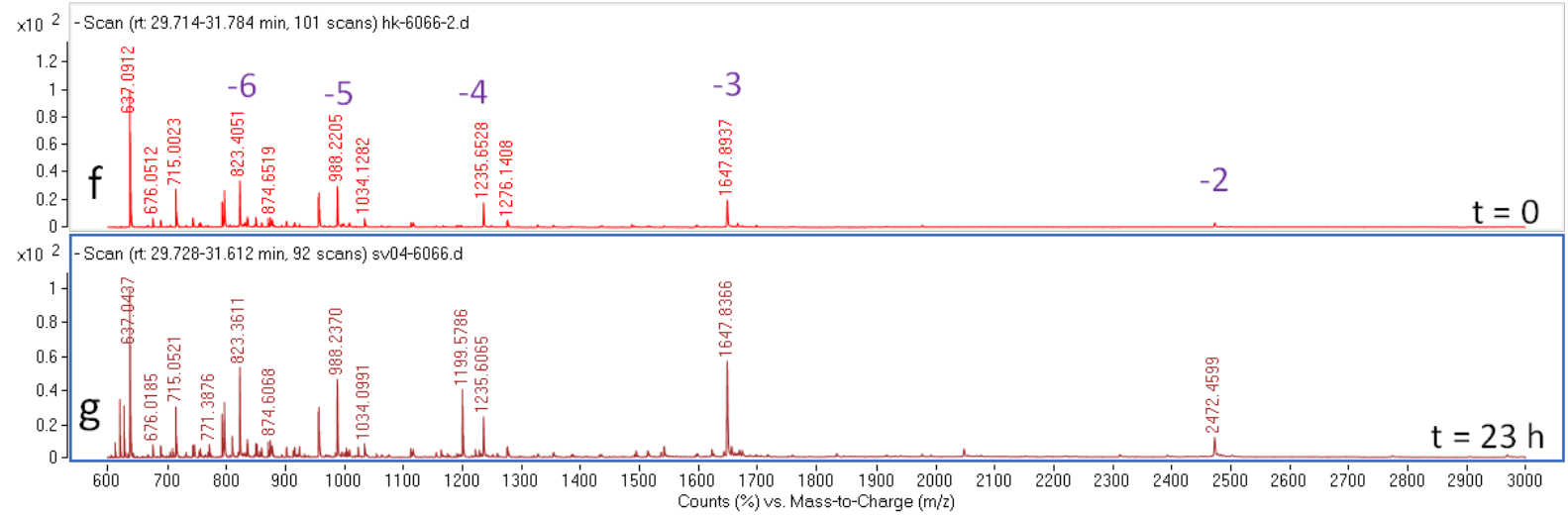

Figure S32. LCMS Analysis of TMO7 at Various Time-points During SVPDE Assay. Fractions corresponding to TMO7 were collected during analytical RP-HPLC runs after SVPDE treatment at various time points (Figure S31 (b-e): $t=1 h, 4 h, 7 h, 23 h$ ). Figure S31 (f, g) compares the $m / z$ spectra at $t=0$ min (Figure S31a), and $t=23 \mathrm{~h}$ (Figure S31e). SVPDE reaction conditions: $100 \mathrm{mM}$ Tris $\mathrm{pH}$ 9, $14 \mathrm{mM} \mathrm{MgCl} 2,72 \mathrm{mM} \mathrm{NaCl}, 13.3$ $\mu \mathrm{M}$ TMO7, $2 \times 10^{-1} \mathrm{U} / \mathrm{mL}$ SVPDE. 


\section{Thermal Denaturation Studies}

Fluorescein labeled PMO was obtained from Gene Tools, LLC. Thermal denaturation experiments were carried out on a Cary 100 Bio UV-VIS spectrophotometer equipped with a $6 \times 6$ thermostatted multicell holder and Peltier temperature controller. ONs and their complements were mixed in equimolar ratios (1.0 $\mu \mathrm{M}$ in each strand) in $50 \mathrm{mM}$ Tris- $\mathrm{HCl}, 50 \mathrm{mM} \mathrm{KCl}$ and $1 \mathrm{mM} \mathrm{MgCl}_{2}, \mathrm{pH}$ 8.3. Samples were transferred to $1 \mathrm{~mL}$ cuvettes and heated from $15^{\circ} \mathrm{C}$ to $90^{\circ} \mathrm{C}$ at a rate of $1{ }^{\circ} \mathrm{C} / \mathrm{min}$, maintained at $90{ }^{\circ} \mathrm{C}$ for $5 \mathrm{~min}$, and cooled at the same rate to $4{ }^{\circ} \mathrm{C}$ before conducting $\mathrm{Tm}$ measurements. Thermal denaturation curves were acquired at $260 \mathrm{~nm}$ at a ramp rate of $0.5^{\circ} \mathrm{C} / \mathrm{min}$. The datasets were analyzed and processed with Cary WinUV software. Tm values were calculated as the maximum of first-derivative plots of absorbance versus temperature and have an uncertainty of $\pm 1{ }^{\circ} \mathrm{C}$. Examples of Tm curves obtained during these experiments are shown below.
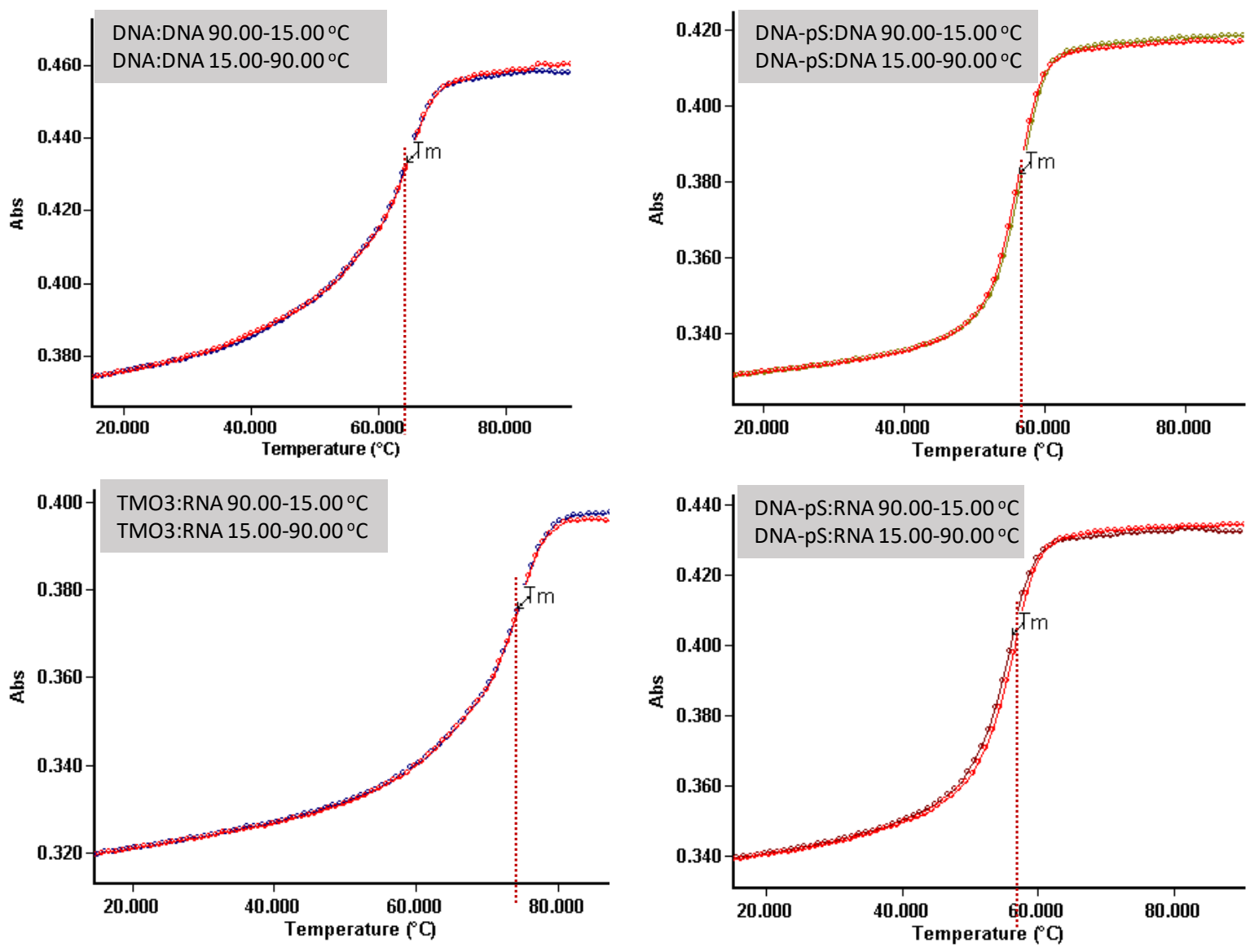

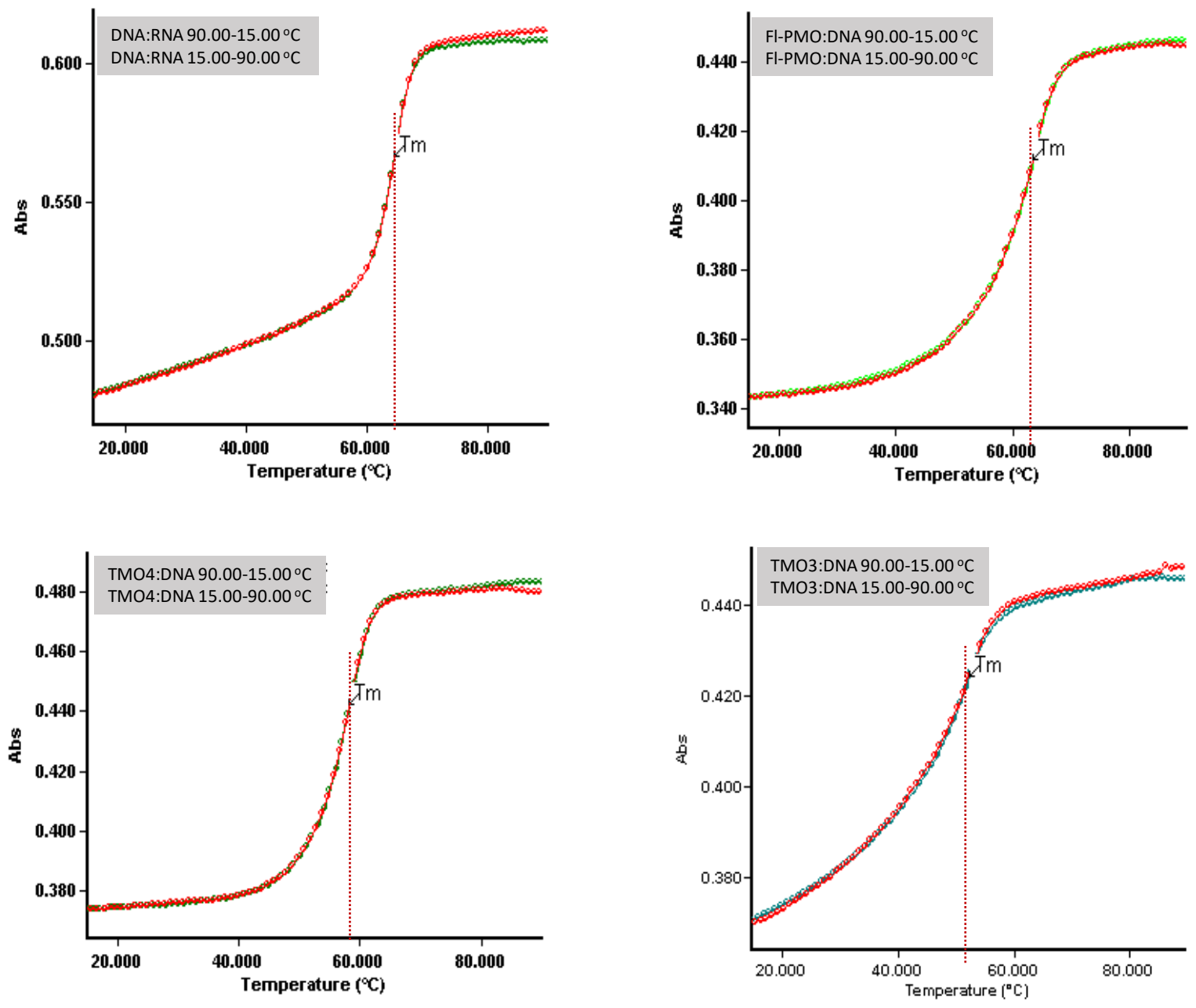

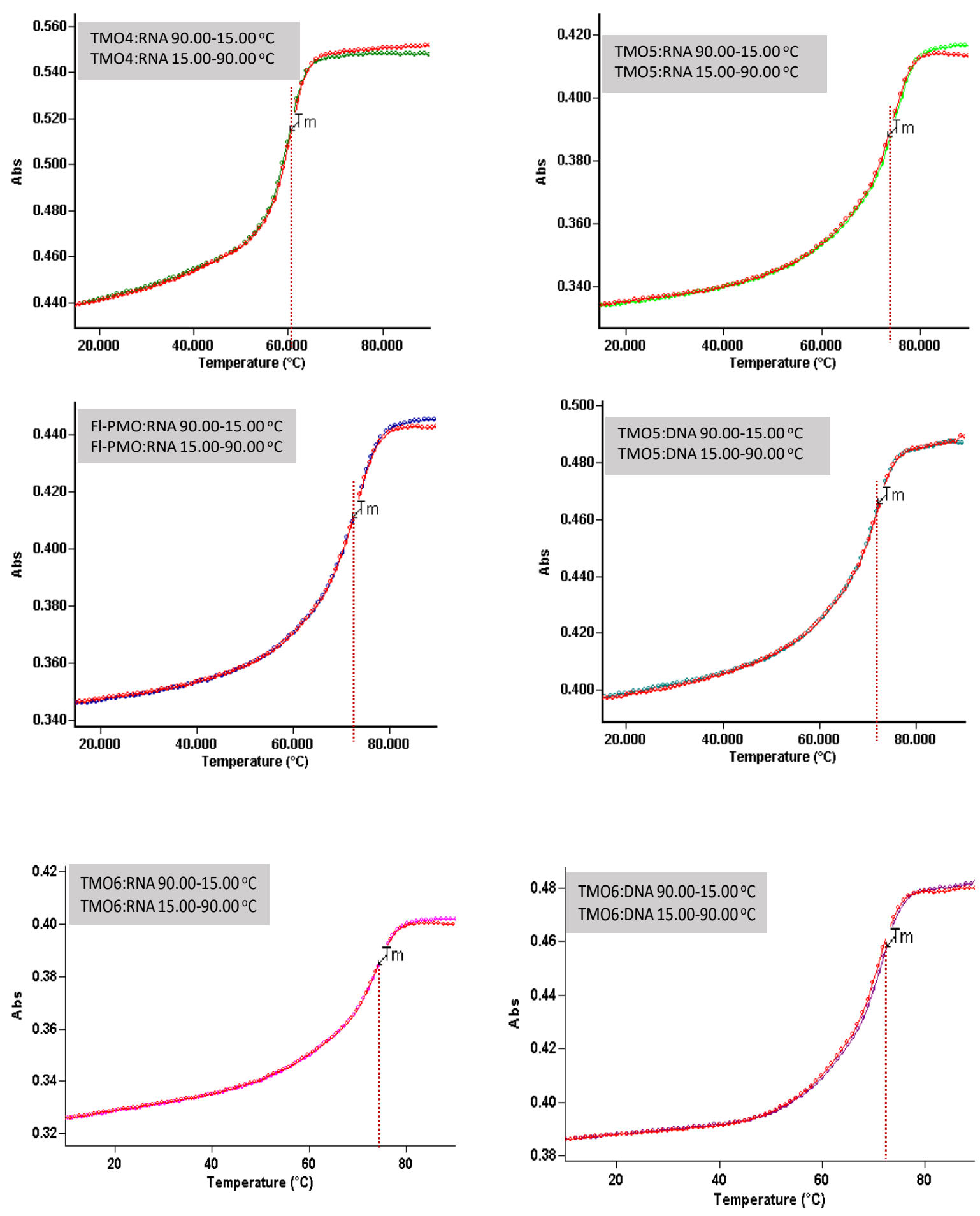

Figure S33. UV melting profiles of TMOs 3-6, DNA-pS, FI-PMO and canonical DNA when duplexed with complementary DNA or RNA. 


\section{RNase H1 Experiments}

To prepare the annealed heteroduplexes, 5'-Fluorescein labeled RNA was mixed with TMO3, TMO4 or DNA-pS control ON (5 $\mu \mathrm{M}$ in each strand, $1 \mathrm{mM} \mathrm{MgCl}, 50 \mathrm{mM} \mathrm{KCl}, 10 \mathrm{mM}$ Tris- $\mathrm{HCl}, \mathrm{pH} 8.3$ ), and the reaction mixtures were heated to $90{ }^{\circ} \mathrm{C}$ followed by slow cooling to $4{ }^{\circ} \mathrm{C}$ over a period of $2 \mathrm{~h}$. To assay for RNase $\mathrm{H} 1$ activity, $50 \mu \mathrm{L}$ of the oligonucleotide: $5^{\prime}$-FI-RNA duplex (100 nM in each strand in RNase $\mathrm{H} 1$ buffer) and $100 \cup$ E. Coli RNase $\mathrm{H} 1$ (New England Biolabs, MA) were mixed and incubated at $37^{\circ} \mathrm{C}$ for $1 \mathrm{~h}$. The reaction mixture was denatured by heat inactivation at $65^{\circ} \mathrm{C}$ for $20 \mathrm{~min}$ and snap frozen in dry ice. Samples were stored at $-20^{\circ} \mathrm{C}$ until PAGE analysis was carried out. Control duplexes of each sample were prepared using the same protocol except that no RNase $\mathrm{H} 1$ enzyme was added. The untreated control samples were subjected to the same conditions as above. After adding DNA loading dye, samples were loaded onto $14 \mathrm{~cm} \times 16 \mathrm{~cm} \times 2 \mathrm{~mm}$ gels (15\% gel, $8.0 \mathrm{M}$ Urea) and PAGE was carried out using a running buffer containing $89 \mathrm{mM}$ Tris, $89 \mathrm{mM}$ boric acid and $2 \mathrm{mM}$ EDTA sodium buffered at pH 9.0 (1X TBE). Following gel electrophoresis, the 5'-Fluorescein labeled RNA and its degraded fragments (those that still retained the fluorescein label) were visualized using a Safe Imager ${ }^{\mathrm{TM}} 2.0$ Blue Light Transilluminator.

\section{Circular Dichroism Experiments}

Prior to annealing the duplexes, oligonucleotide concentrations were calculated based on absorbance values measured at $25{ }^{\circ} \mathrm{C}$. The samples were prepared in $10 \mathrm{mM}$ Tris- $\mathrm{HCl}, 50 \mathrm{mM} \mathrm{KCl}, 1 \mathrm{mM} \mathrm{MgCl}, \mathrm{pH}$ $8.3,10 \mu \mathrm{M}$ in each strand. Prior to $\mathrm{CD}$ experiments, the samples were heat-denatured for two minutes at $90{ }^{\circ} \mathrm{C}$ and slowly cooled to $4{ }^{\circ} \mathrm{C}$ over a period of 4 hours. CD spectra were recorded on an Applied Photophysics Chirascan ${ }^{\mathrm{TM}}$ Plus spectrometer at $25^{\circ} \mathrm{C}$, in the $200-350 \mathrm{~nm}$ wavelength range using custommade $0.5 \mathrm{~mm}$ pathlength cuvettes. The buffer spectrum was subtracted from each CD duplex spectrum prior to data analysis.

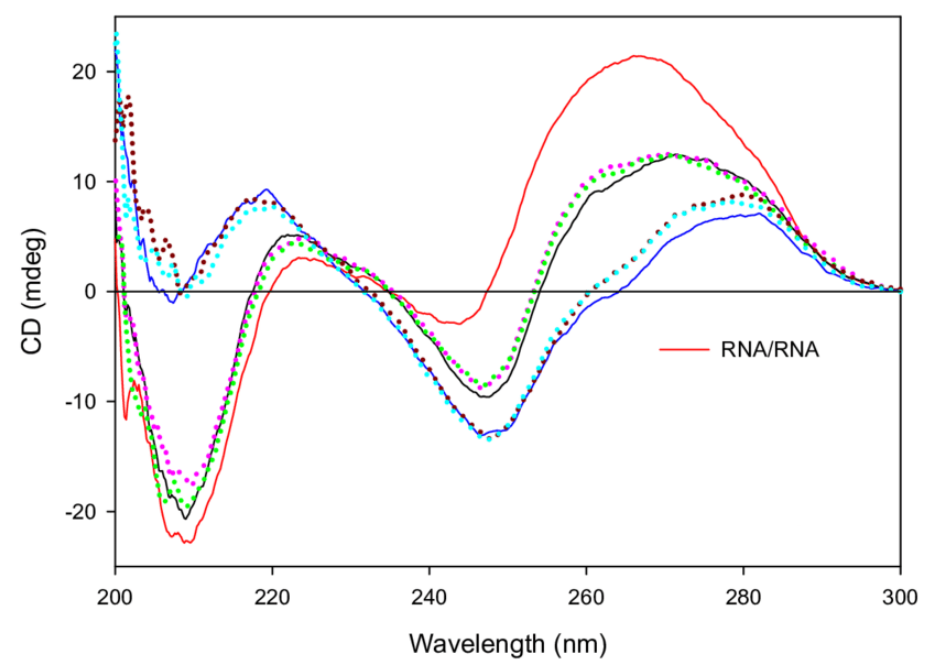

Figure S34. This figure has been reproduced with permission from reference [2]. Copyright 2000-2020 ARKAT-USA, Inc. This figure provides an example of a typical CD spectra for native RNA/RNA duplex (red curve, A-type duplex). Sequence: 3'-r(CUU CUU UUU UAC UUC) with complementary RNA. Conditions: 10 $\mu \mathrm{M}$ ON concentration, $20^{\circ} \mathrm{C}, 60 \mathrm{mM}$ Tris- $\mathrm{HCl}(\mathrm{pH} 7.5), 60 \mathrm{mM} \mathrm{KCl}, 0.8 \mathrm{mM} \mathrm{MgCl}_{2}$. 
The HeLa-15b cell line was a kind gift from miRagen Therapeutics Inc., Boulder, CO. Cells were cultured in Dulbecco's Modified Eagle's Medium (DMEM) supplemented with $10 \%$ fetal bovine serum (FBS) and penicillin-streptomycin $(1 \%)$ at $37^{\circ} \mathrm{C}$ and $5 \% \mathrm{CO}_{2}$. The cells were grown in 96-well plates and transfected in antibiotic-free, full-serum medium using the desired concentration of TMOs 3-6, TMO9 or the 2'-OMecontrol complexed with Oligofectamine ${ }^{\mathrm{TM}}$ transfection reagent. The cells were harvested at $24 \mathrm{~h}$ (preliminary screen), $48 \mathrm{~h}$ and $72 \mathrm{~h}$ time points and analyzed using the Dual-Luciferase Reporter (DLR) Assay System (Promega) according to the manufacturer's instructions. The luminescence signal arising from the Firefly and Renilla Luciferase were measured sequentially in each well using a Filter-max F5 luminometer (Molecular Devices). The signal from the Firefly Luciferase reporter is measured by adding freshly prepared Luciferase Assay Reagent to generate a luminescent signal. After quantifying the Firefly luminescence, this reaction was quenched, and the Renilla Luciferase signal was generated by adding Stop \& Glo Reagent to each well. The resultant Renilla Luciferase signal was then quantified. The ratio of Renilla Luciferase signal to Firefly signal (RLuc/FLuc) in each well was calculated and these values were normalized to the ratios obtained from Oligofectamine-transfected cells (mock controls). The experiment was repeated at various oligonucleotide concentrations to assess the dose-response of each oligonucleotide over the concentration range of $1 \mu \mathrm{M}-0.1 \mu \mathrm{M}$ (SI Chart S1) and 10nM-100 nM (Chart 1, main text).

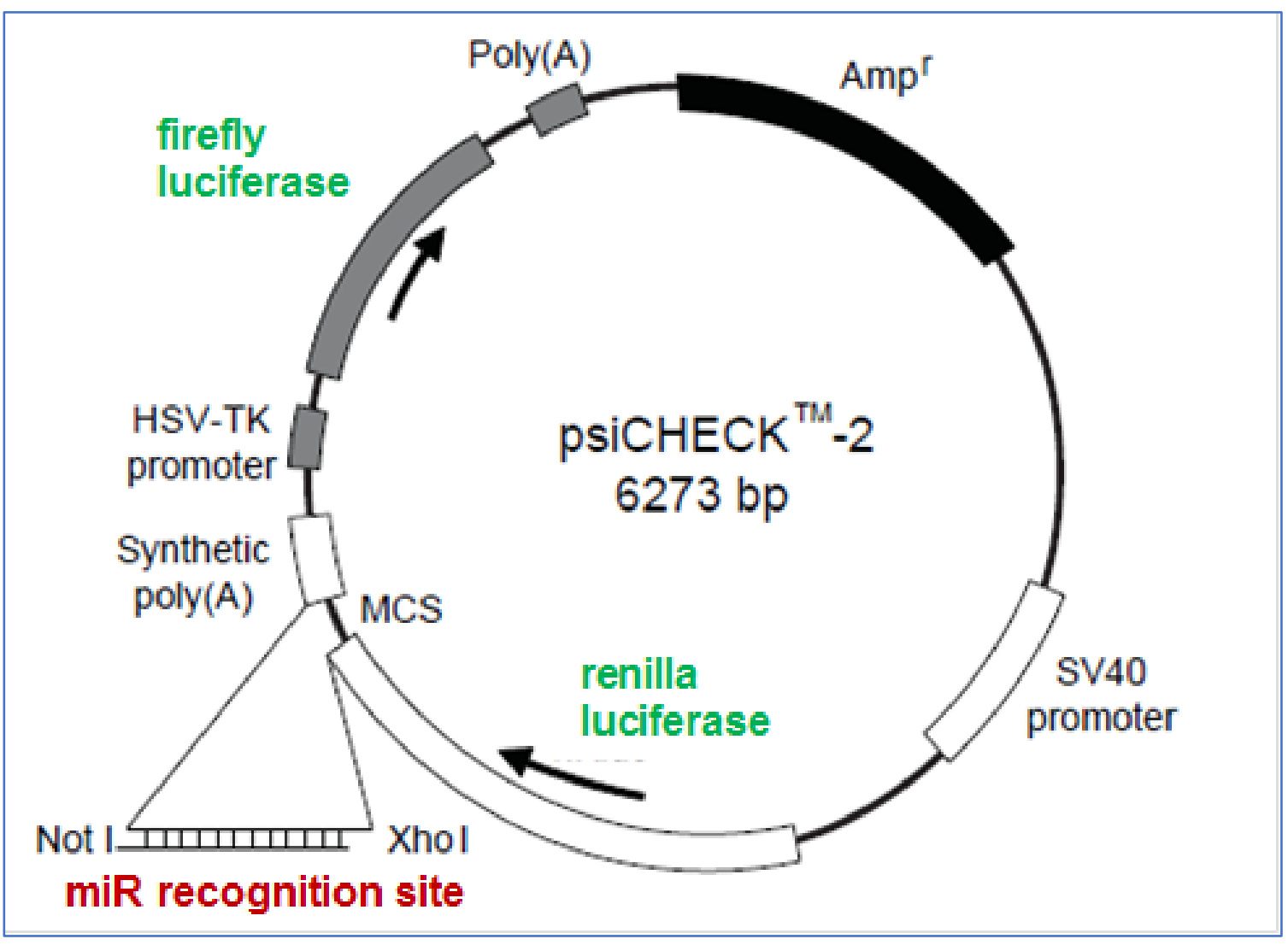

Figure S35. Vector map for the HeLa-15b plasmid. 


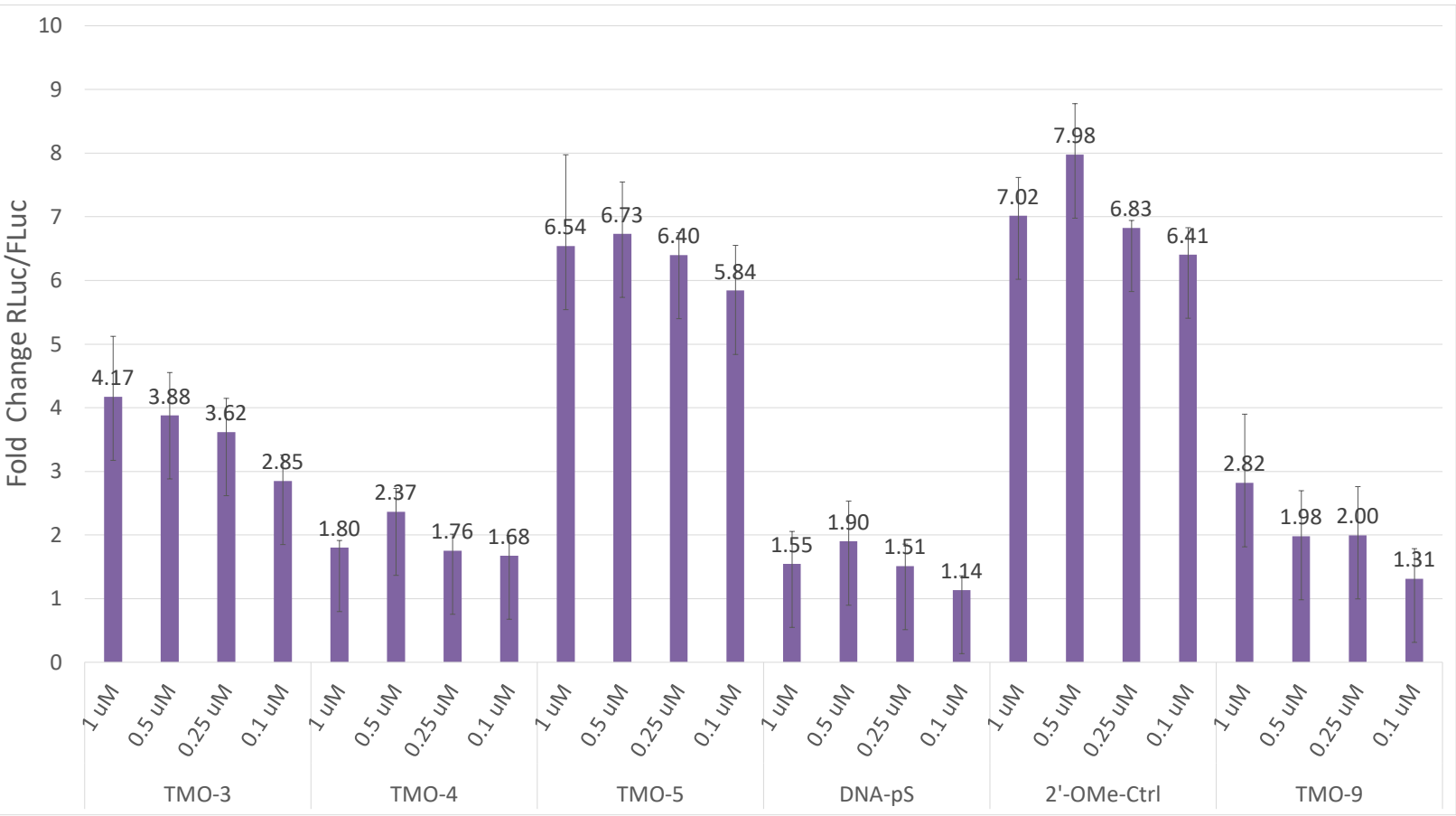

Chart S1. Bioactivity screen of TMOs 3-5 as microRNA-15b-5p inhibitors in the high concentration range (100-1000nM). Dual-luciferase reporter assay was performed to test the activity of TMO-based anti-miRs targeting hsa-miR-15b-5p. A HeLa-15b cell line engineered to express a dual reporter plasmid containing Rluc and Fluc mRNA was used for this assay. The perfectly complementary targeting sequence for hsamiR-15b-5p is located in the 3'-UTR of RLuc mRNA (Reporter gene). Firefly Luciferase expressed by the same plasmid was used as the internal control. Transfections were carried out on $60 \%$ confluent Hela-15b cells using Oligofectamine ${ }^{\mathrm{TM}}$ as the transfection reagent. Cells were lysed and analyzed after $24 \mathrm{~h}$ using a Dual-Luciferase reporter assay kit (Promega). Datasets were normalized using the internal firefly luciferase (FLuc) control and reported as a fold change in RLuc with respect to the lipid transfected (mock) control which was set to 1 . Each datapoint represents the mean of four biological replicates per concentration per time point $\pm S D$.

\section{References}

1. Krishna, H.; Jastrzebska, K.; Caruthers, M.; Paul, S.; Veedu Rakesh, N. Thiomorpholino Oligonucleotides For The Treatment Of Muscular Dystrophy. WO 2019/060522 A3, 2018/09/20, 2019.

2. Zhou, C.; Chattopadhyaya, J., New methylene-bridged hexopyranosyl nucleoside modified oligonucleotides (BHNA): Synthesis and biochemical studies. Arkivoc 2008, 2009 (3), pp. 171-186. 


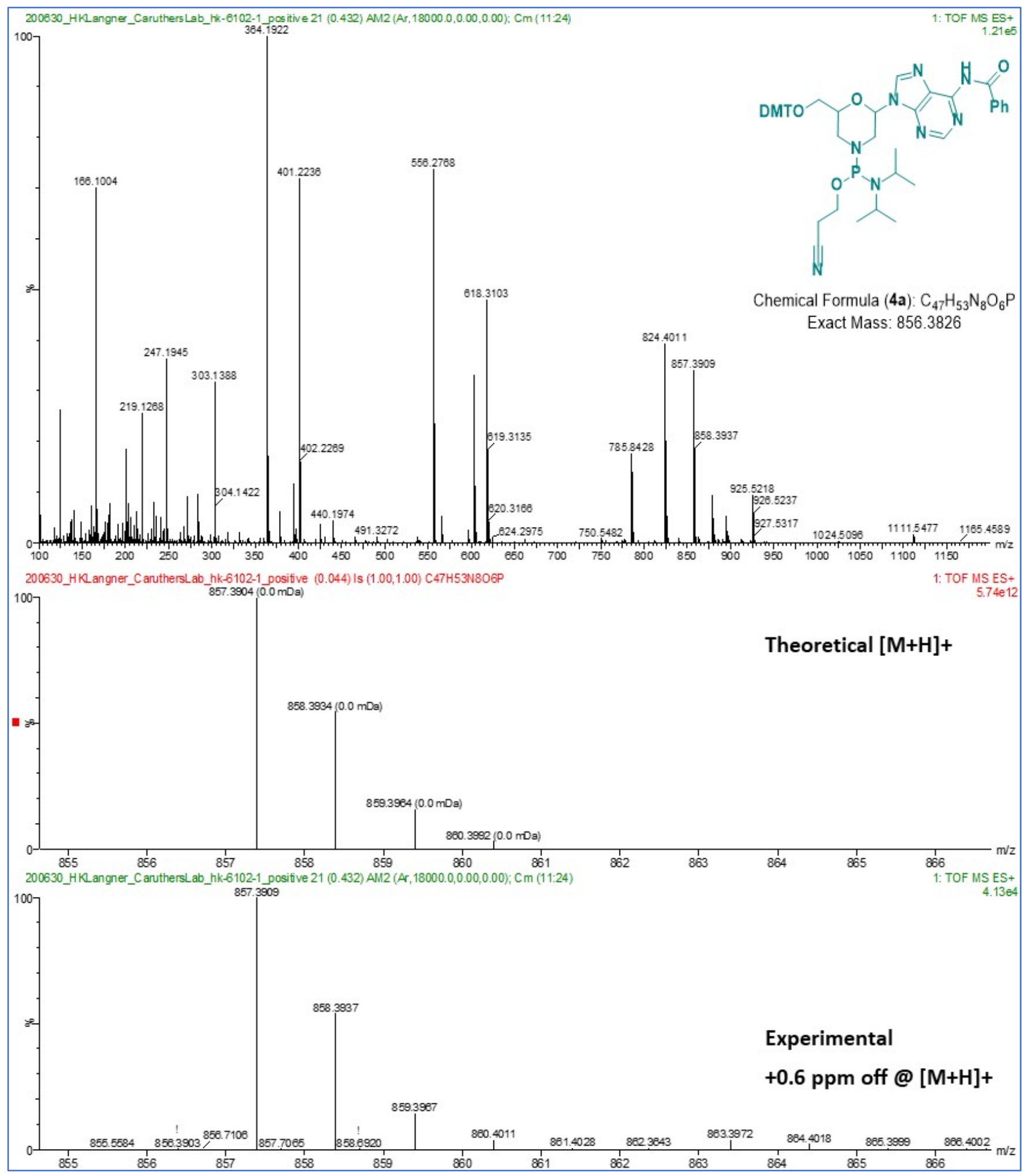

Figure S36. HRMS data for Compound 4a 


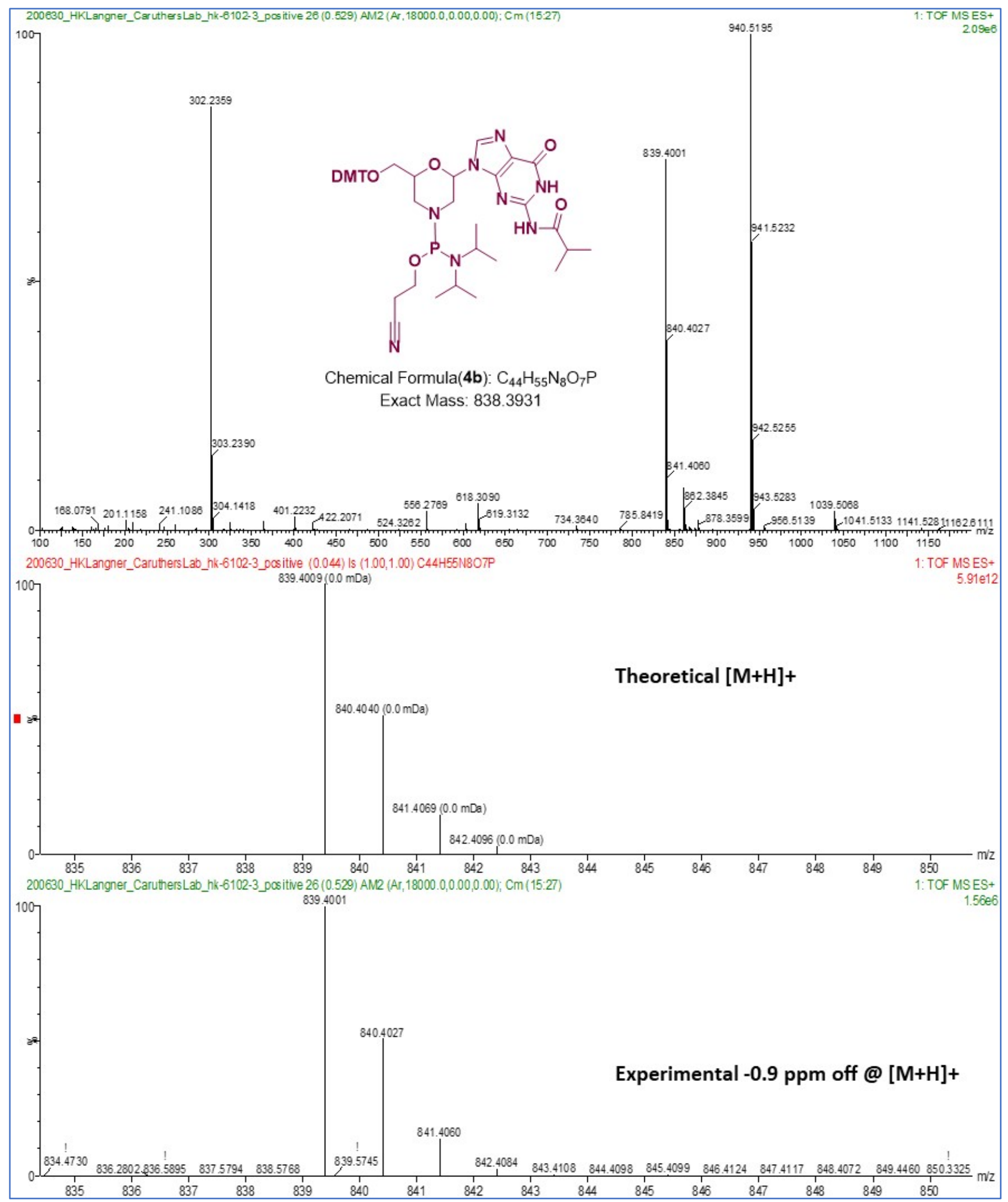

Figure S37. HRMS data for Compound 4b 


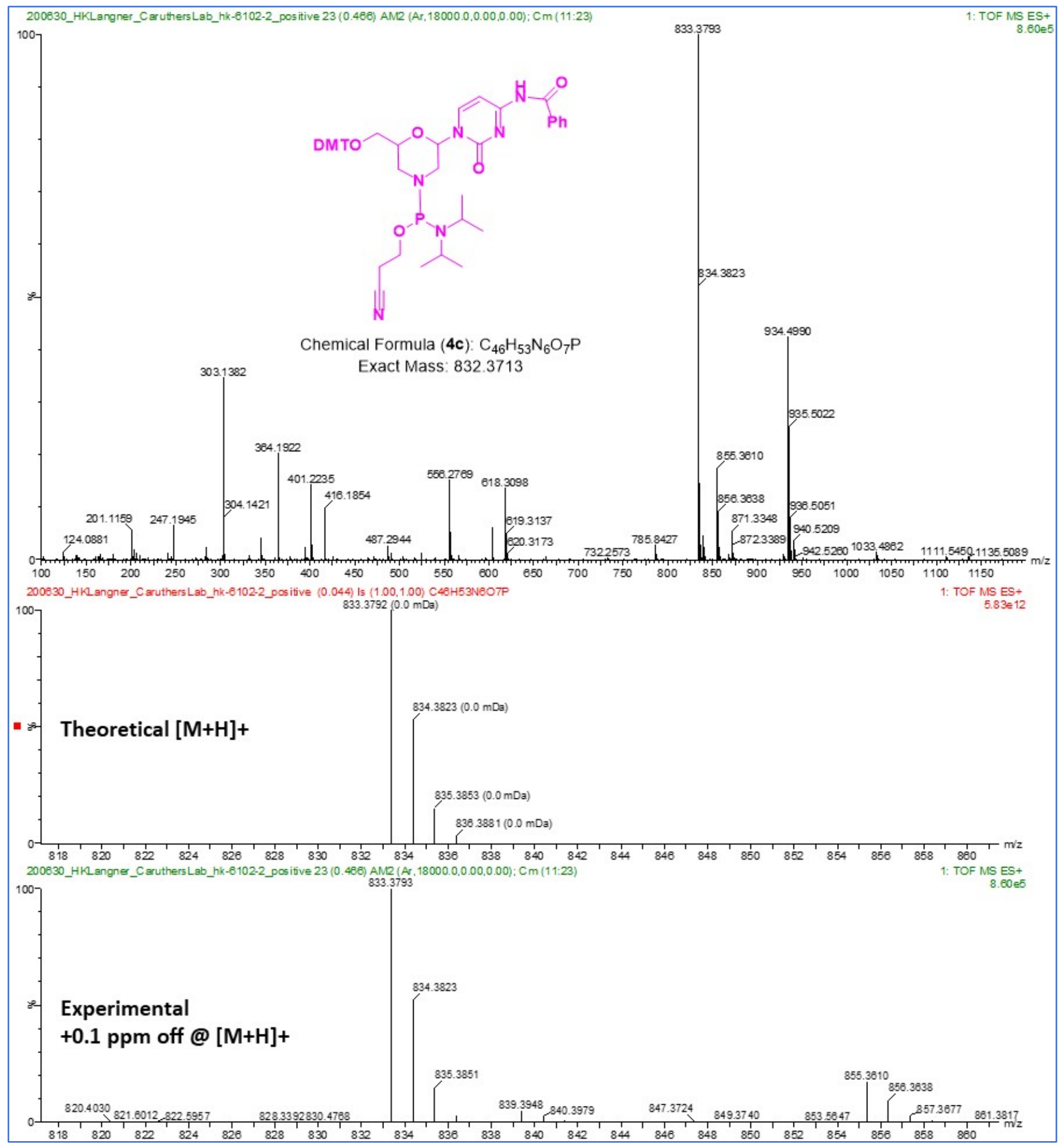

Figure S38. HRMS data for Compound 4c 


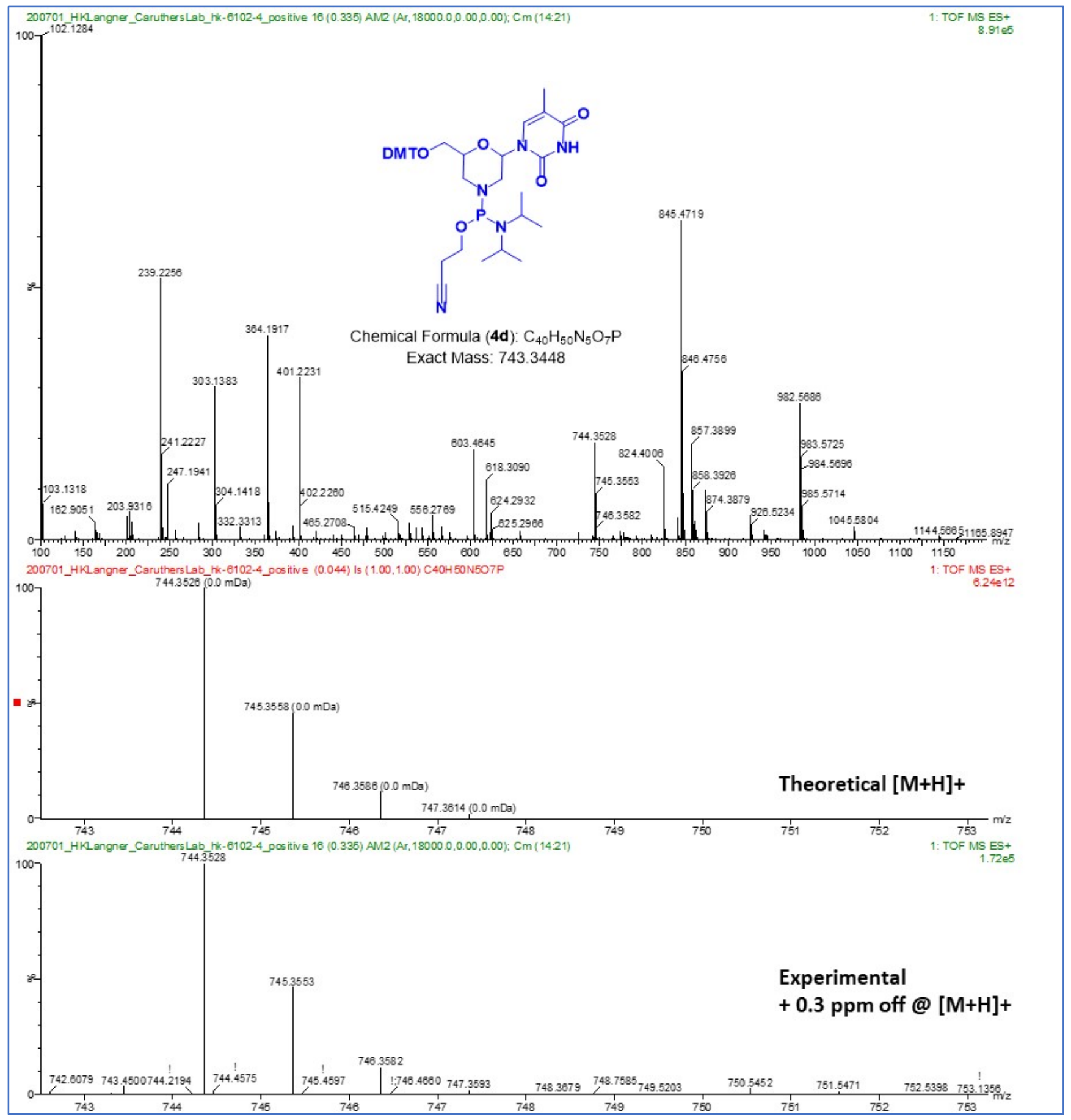

Figure S39. HRMS data for Compound 4d 


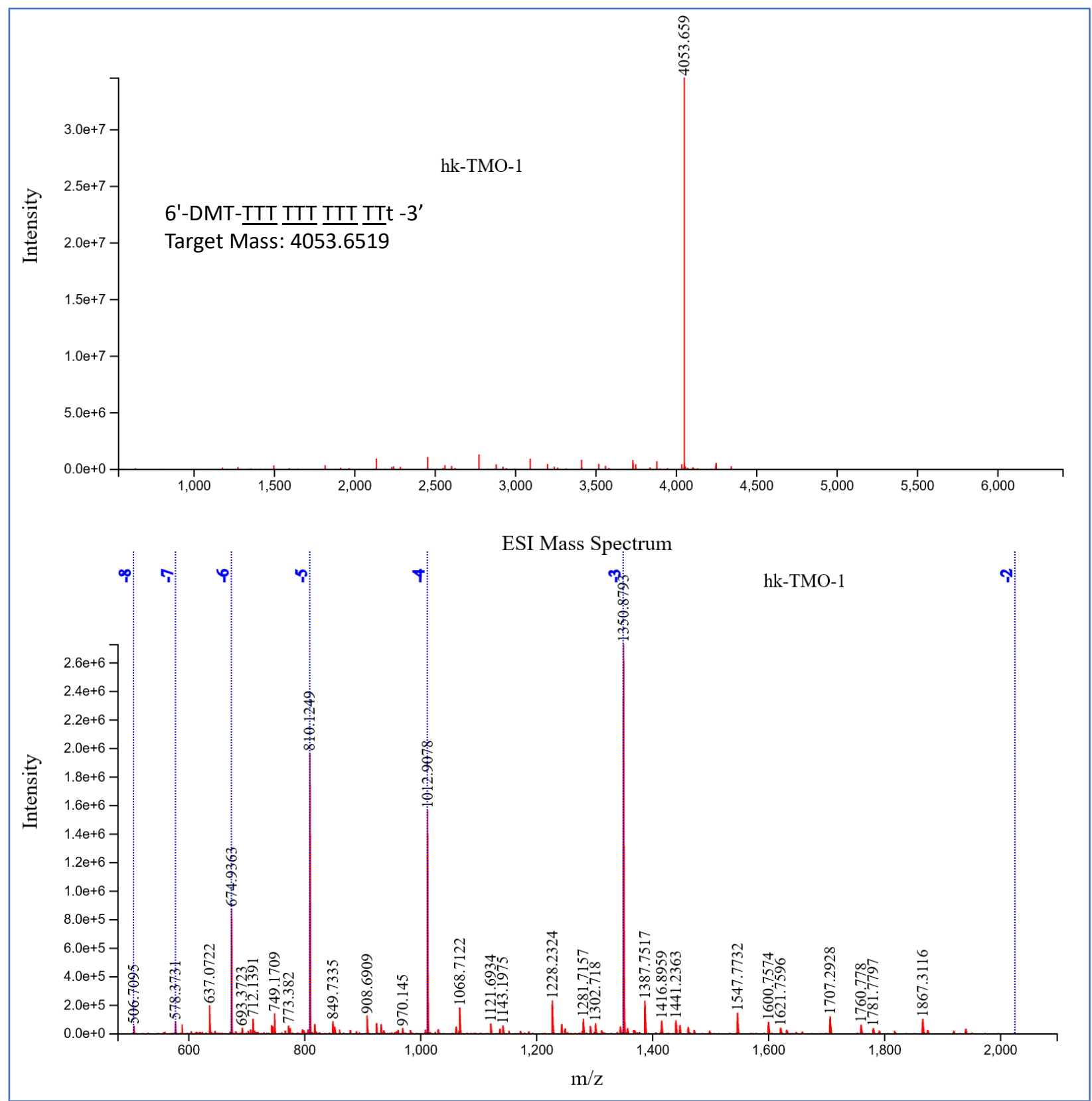

Figure S40. HRMS data for TMO-1 


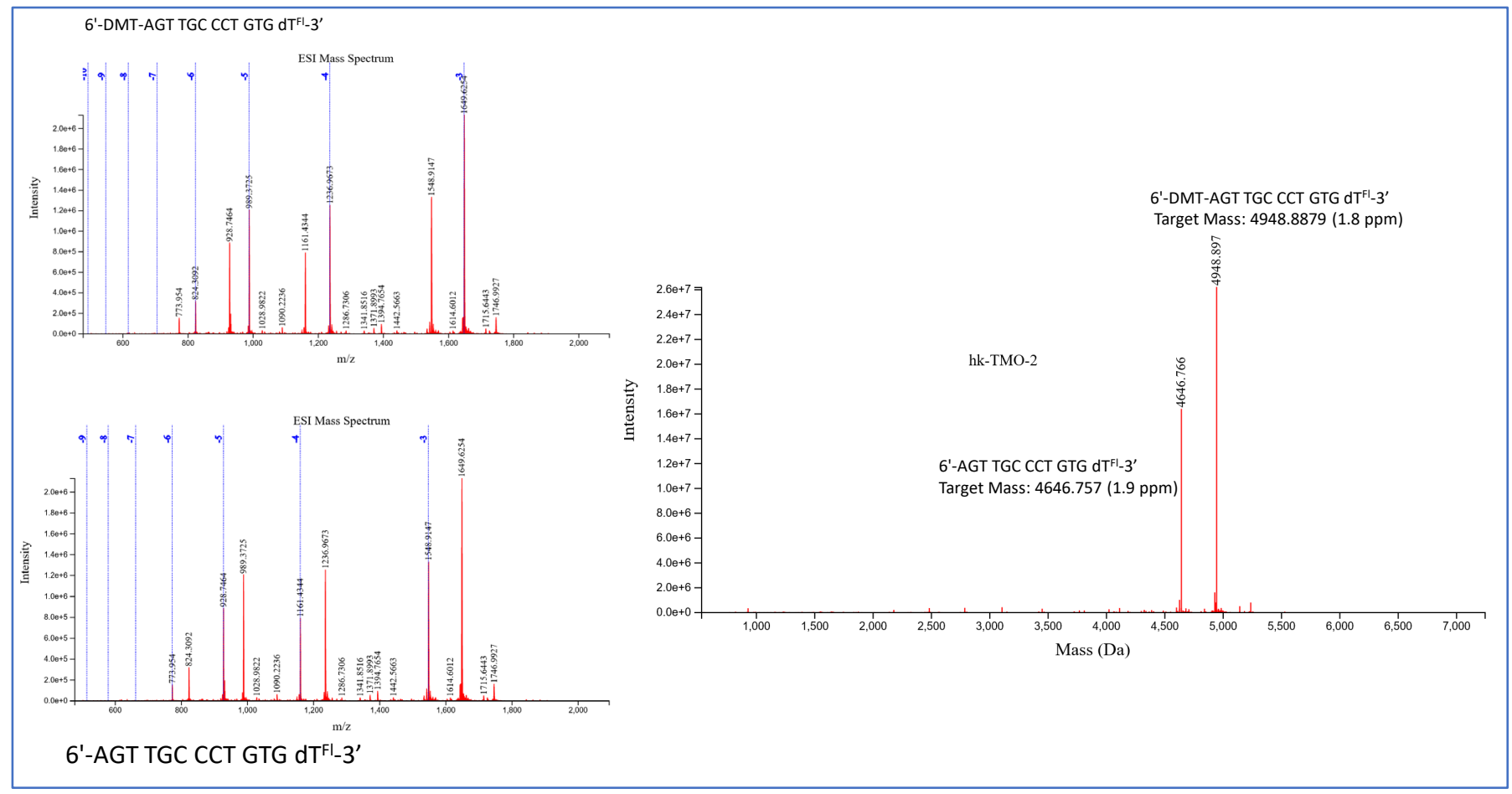

Figure S41. HRMS data for TMO-2 


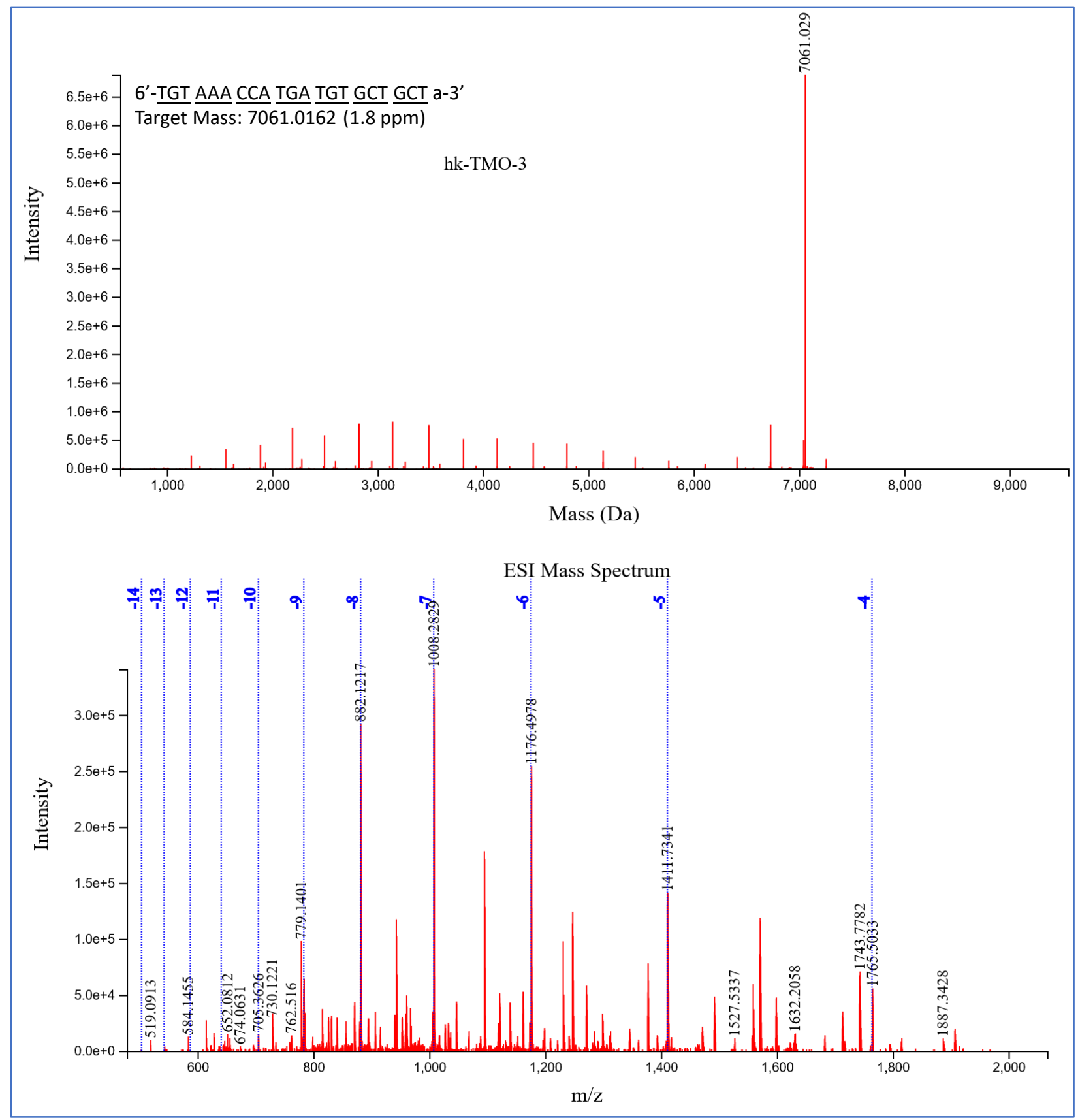

Figure S42. HRMS data for TMO-3 


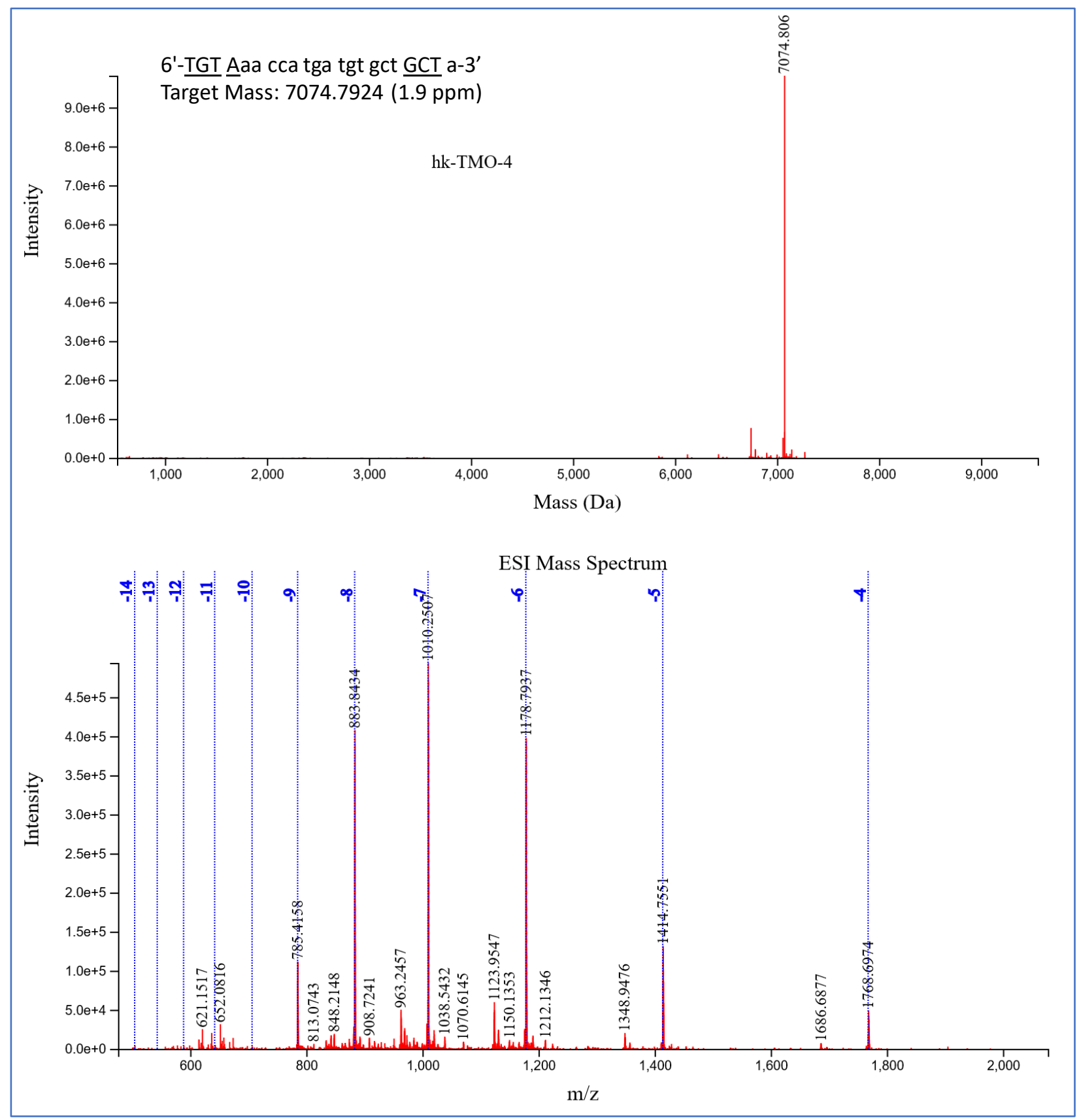

Figure S43. HRMS data for TMO-4 


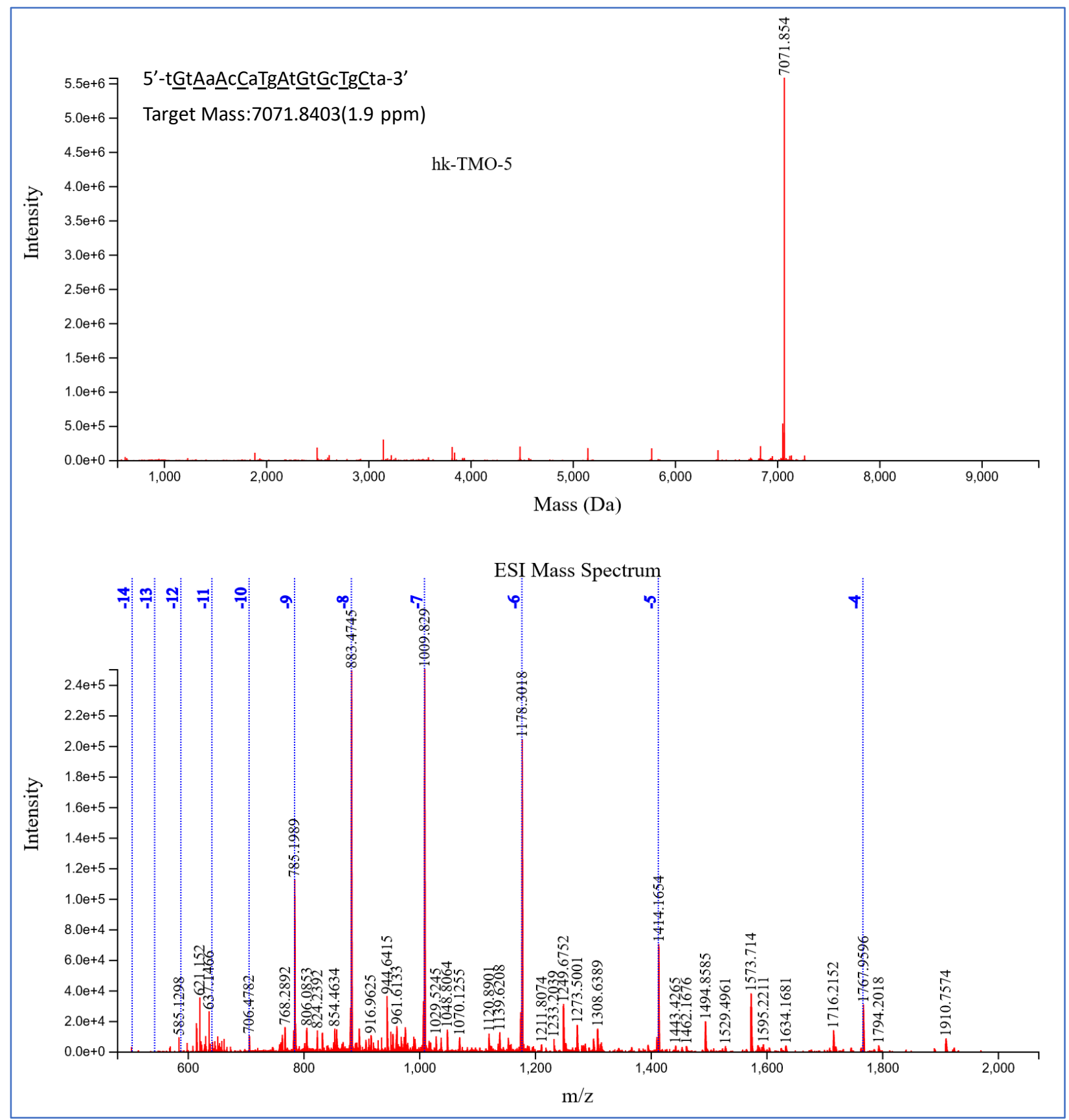

Figure S44. HRMS data for TMO-5 


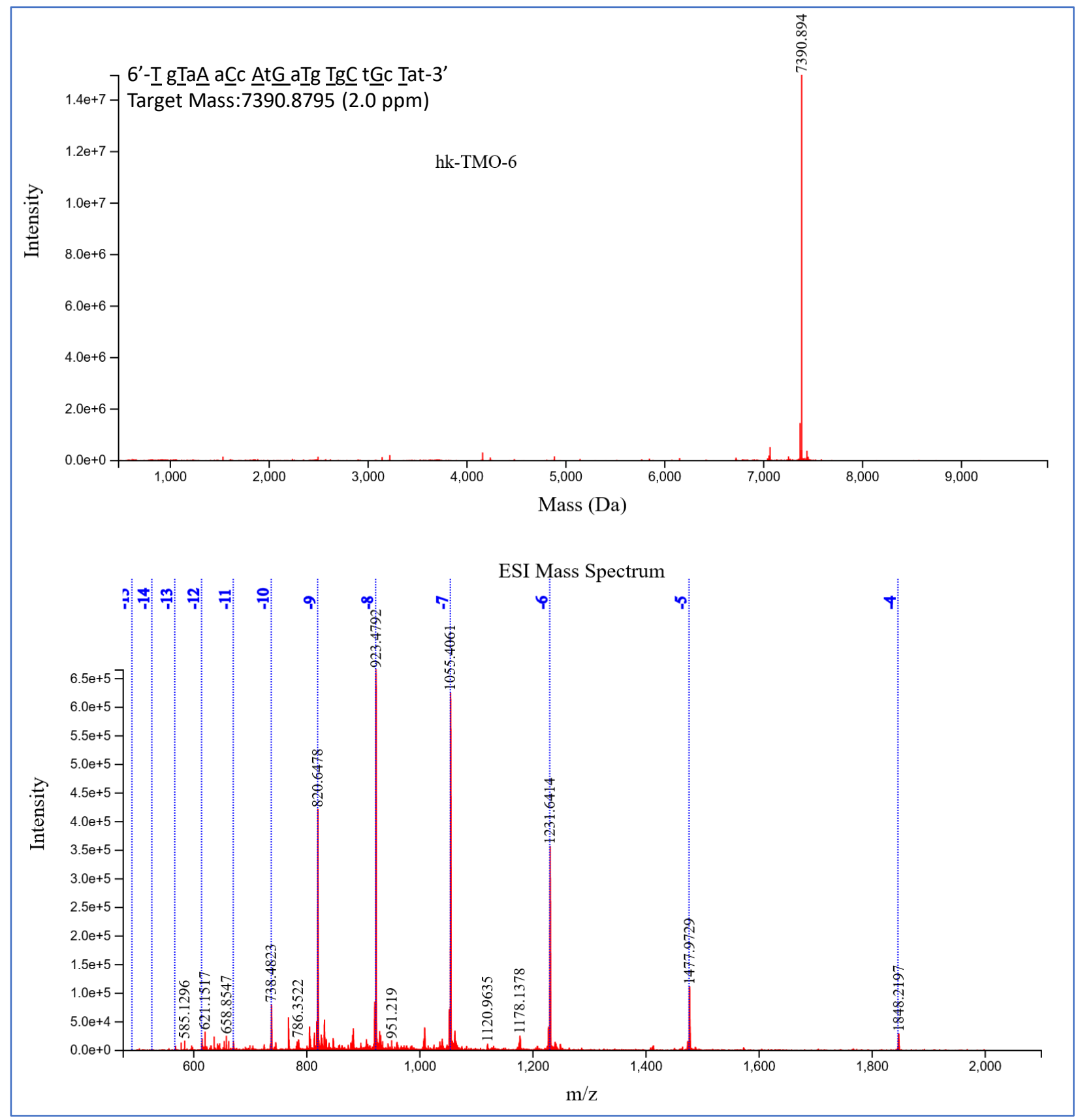

Figure S45. HRMS data for TMO-6 


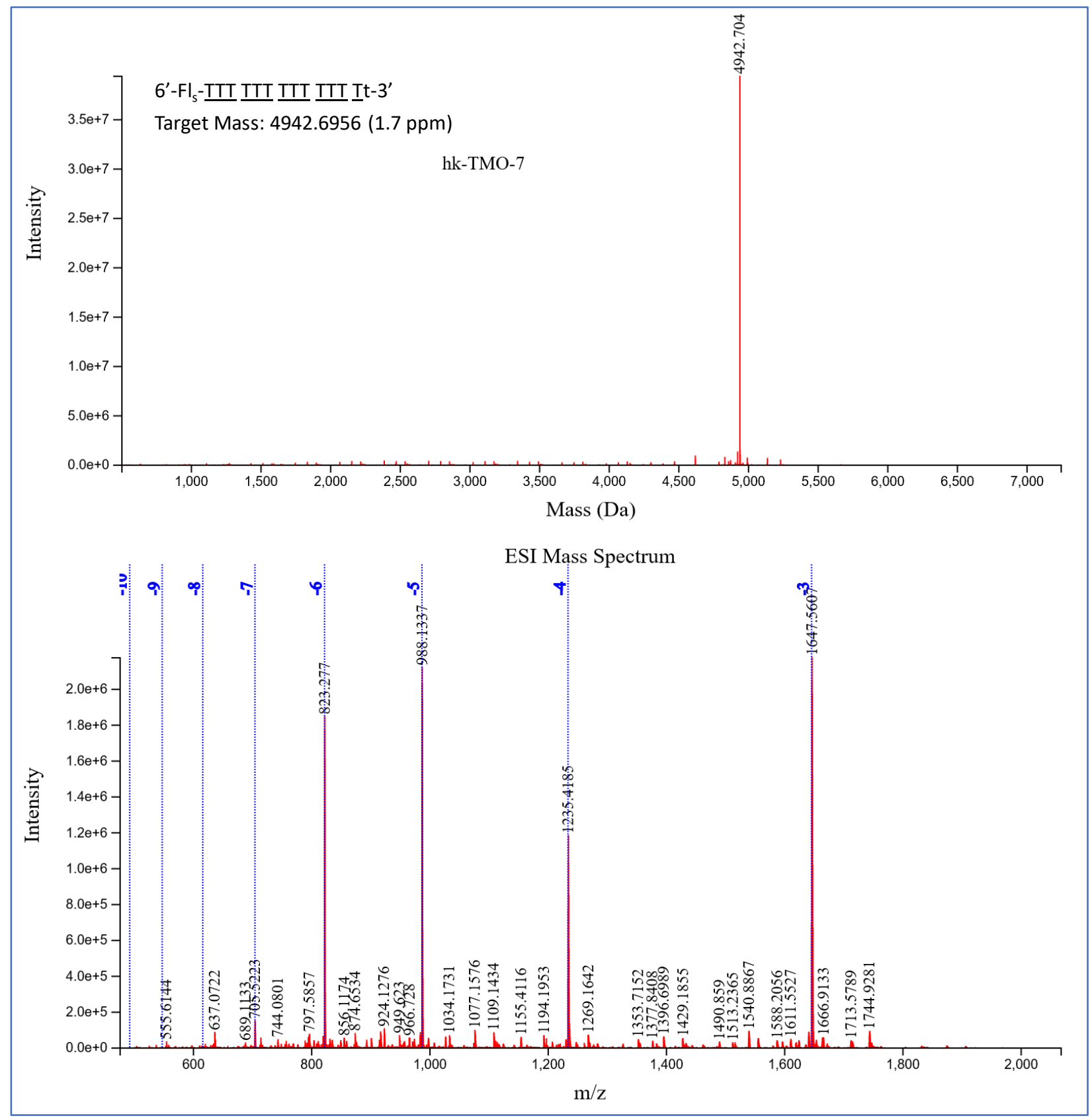

Figure S46. HRMS data for TMO-7 


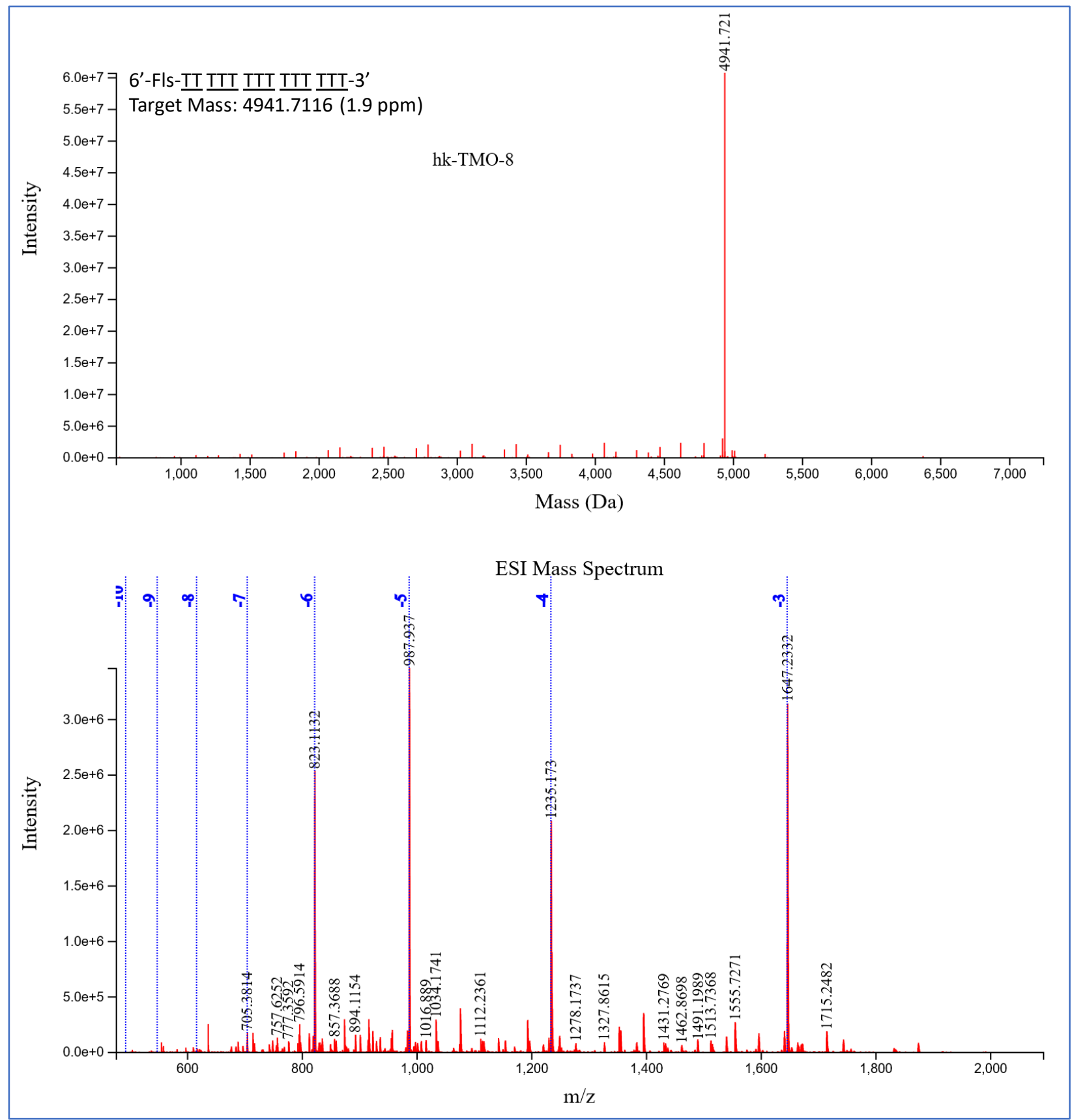

Figure S47. HRMS data for TMO-8 


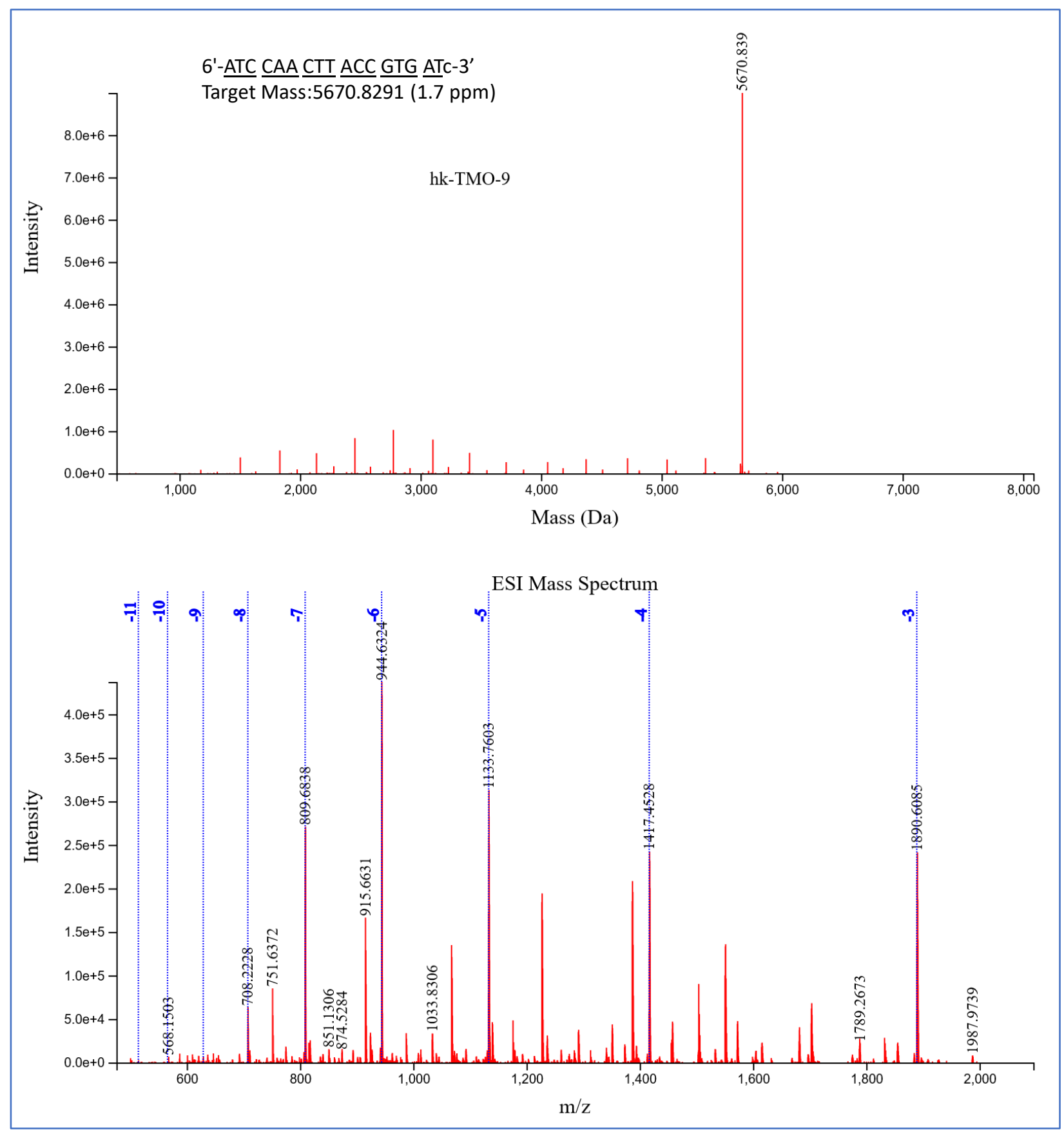

Figure S48. HRMS data for TMO-9 


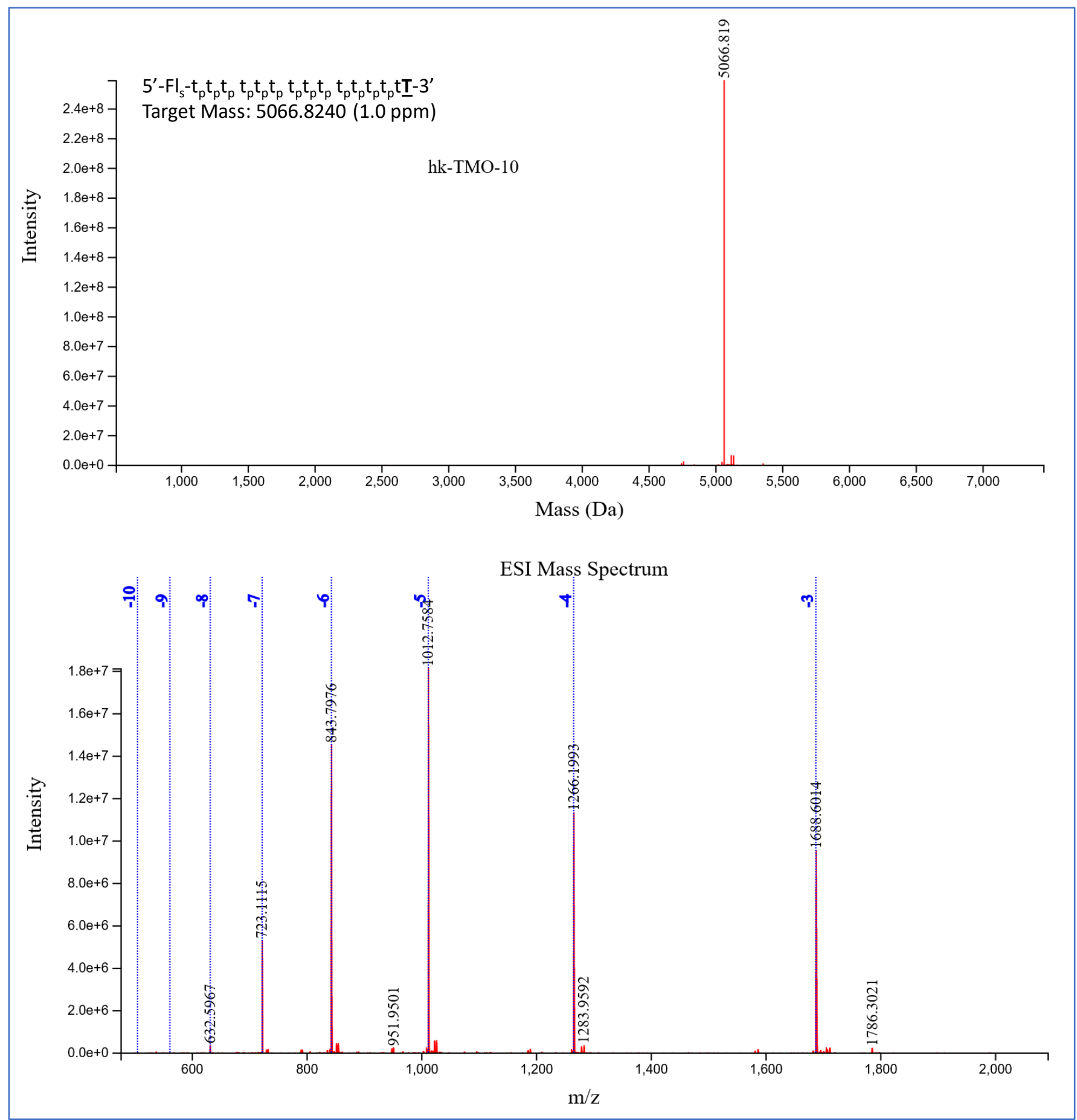

Figure S49. HRMS data for TMO-10 


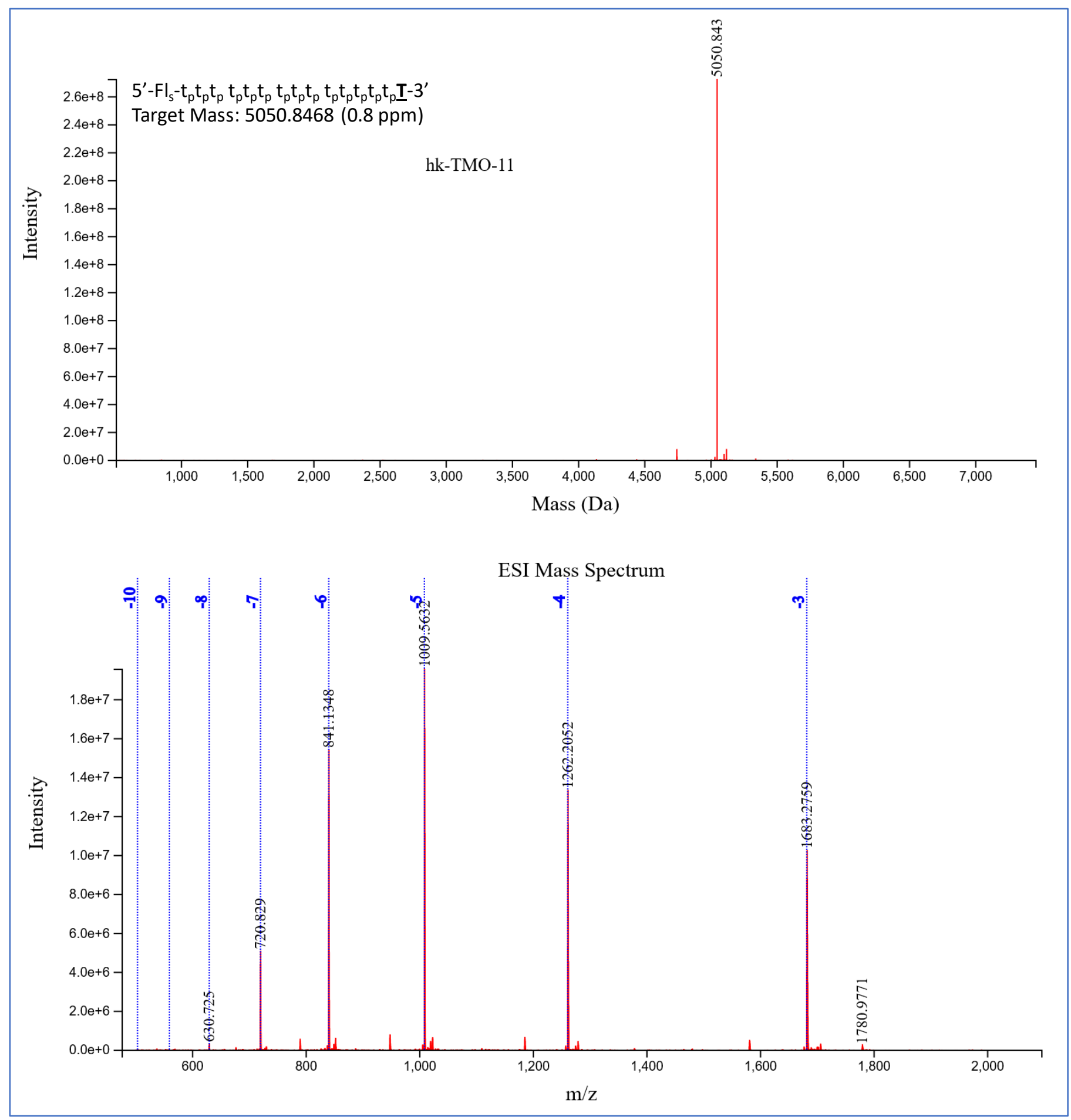

Figure S50. HRMS data for TMO-11 


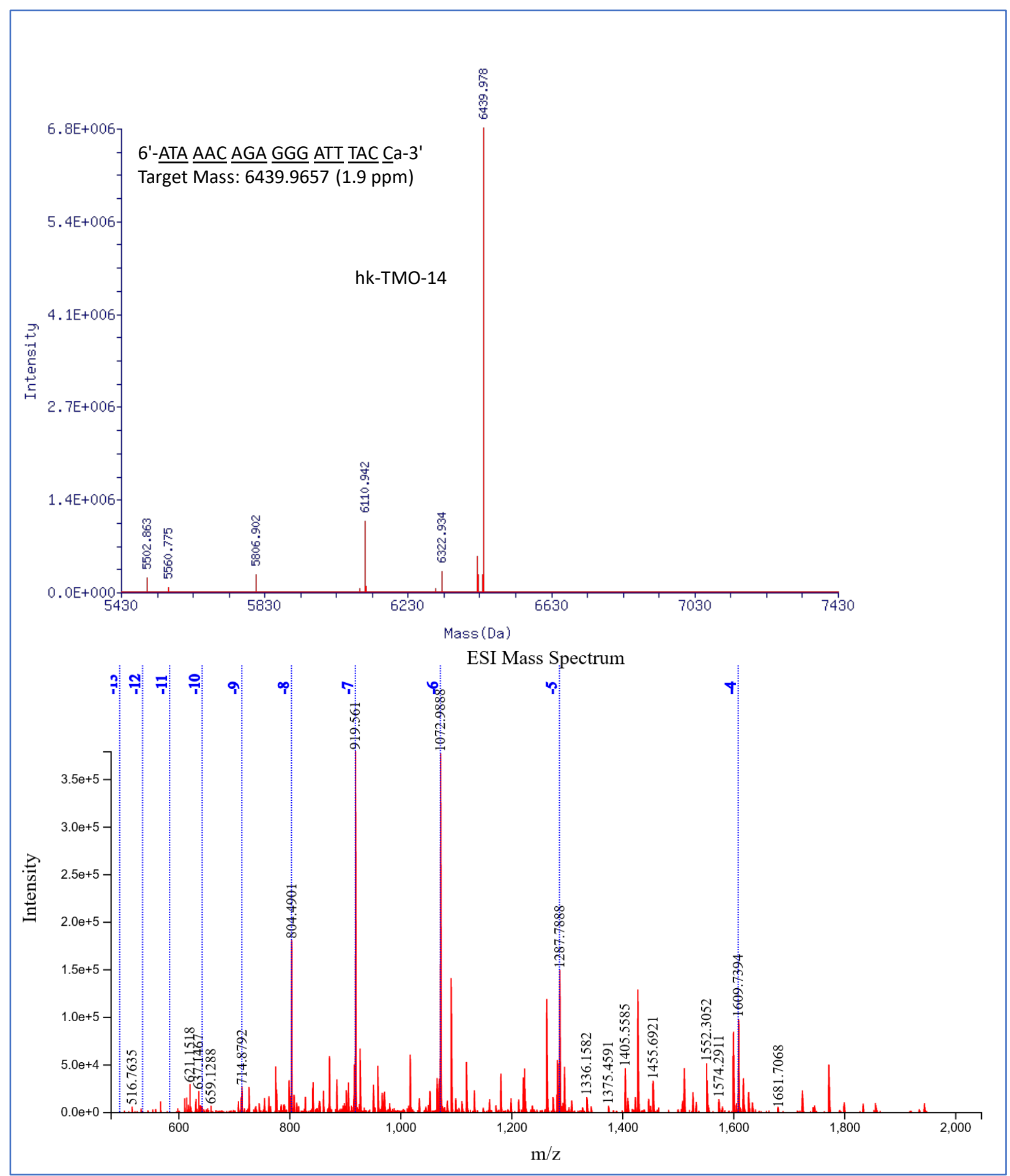

Figure S50. HRMS data for TMO-14 


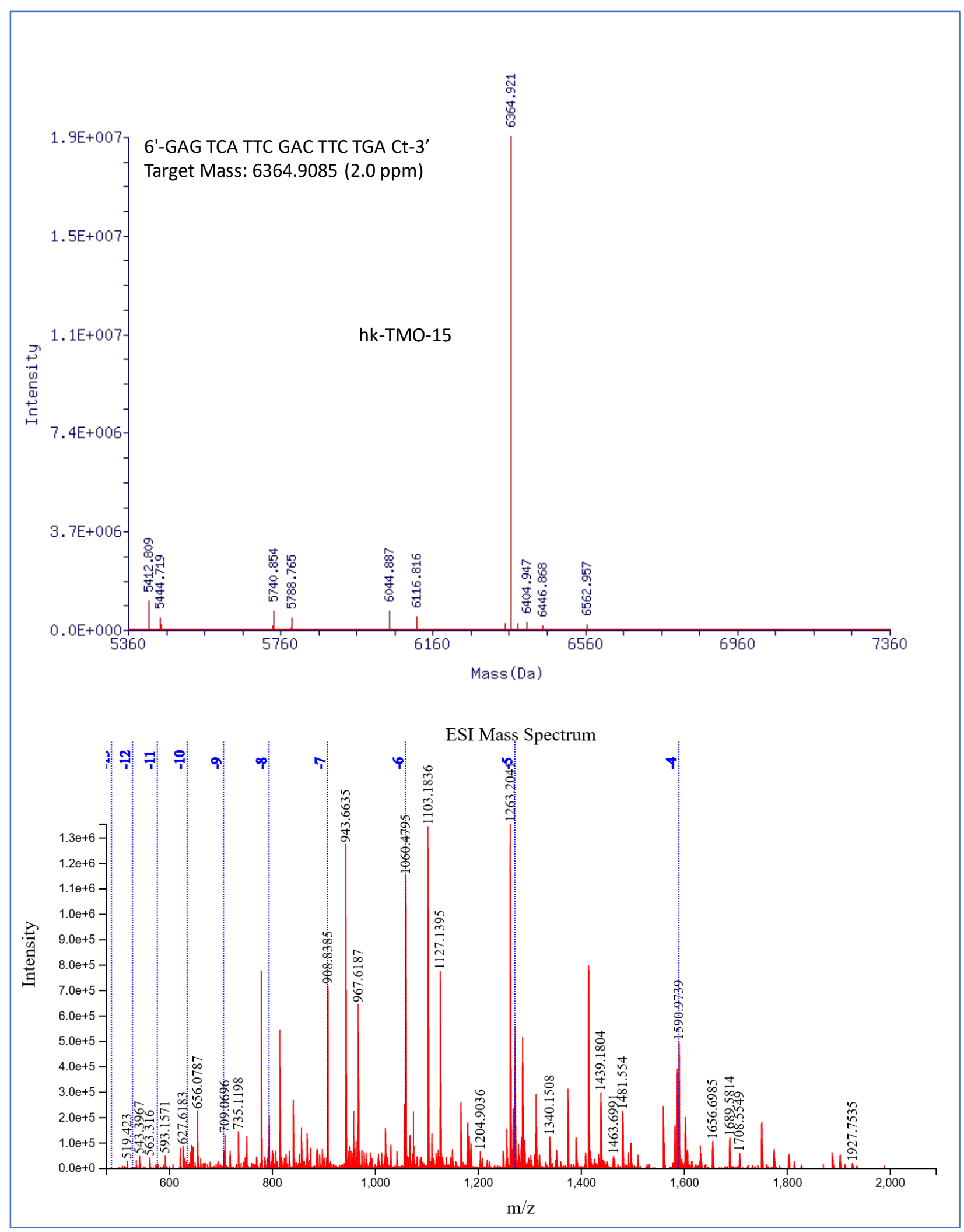

Figure S51. HRMS data for TMO-15 


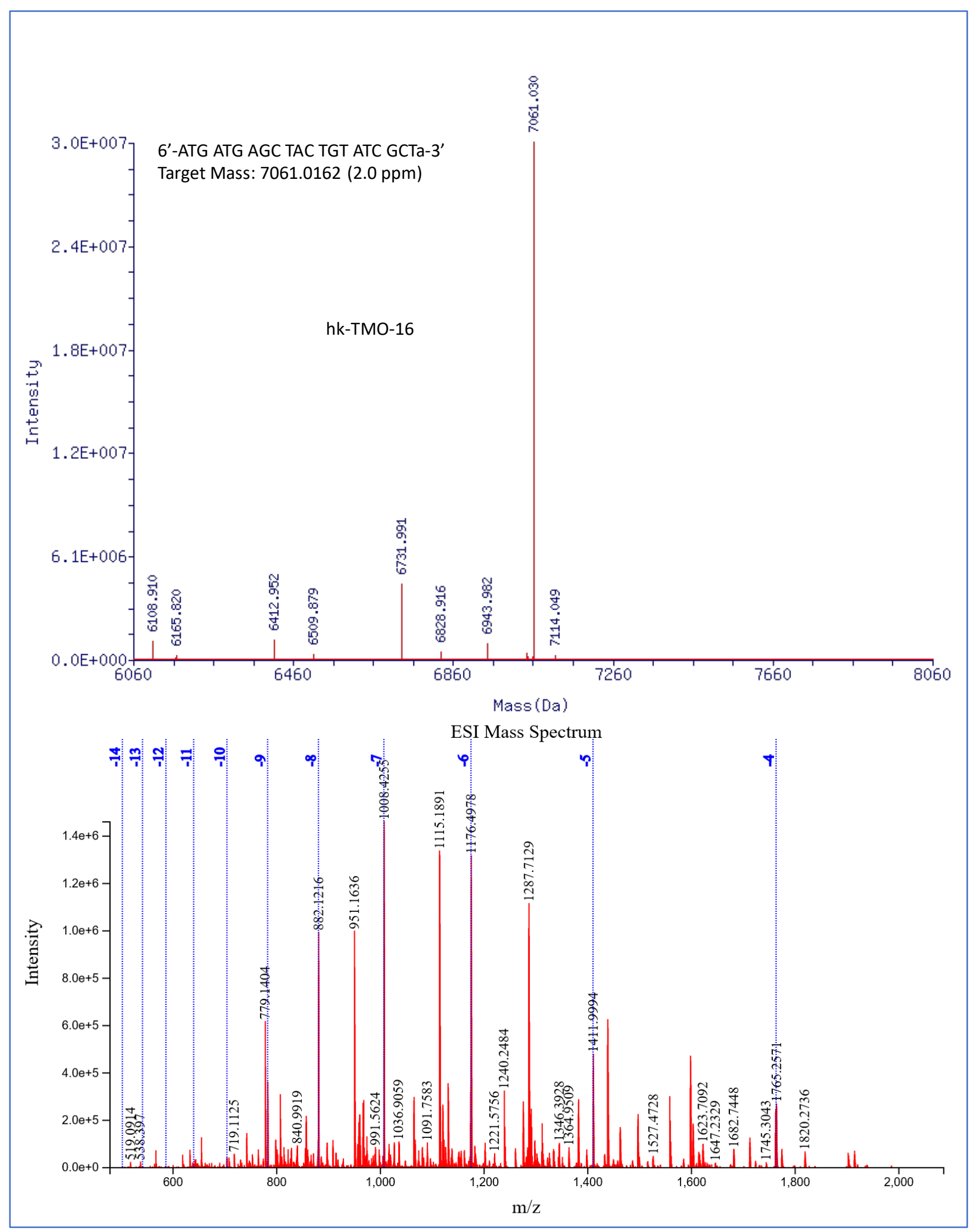

Figure S51. HRMS data for TMO-16 